INTER NATIONAL MONETARY FUND
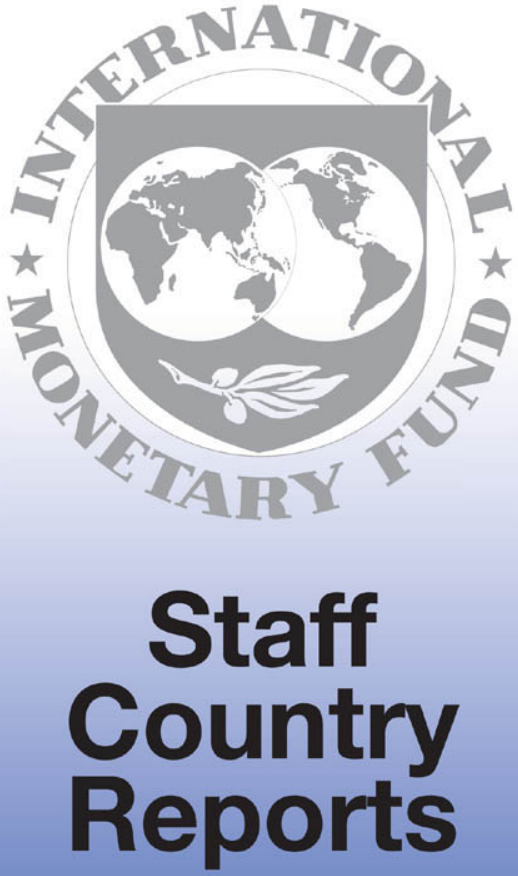


\section{Central African Republic: Selected Issues and Statistical Appendix}

This Selected Issues paper and Statistical Appendix for the Central African Republic was prepared by a staff team of the International Monetary Fund as background documentation for the periodic consultation with the member country. It is based on the information available at the time it was completed on March 11,2004. The views expressed in this document are those of the staff team and do not necessarily reflect the views of the government of the Central African Republic or the Executive Board of the IMF.

The policy of publication of staff reports and other documents by the IMF allows for the deletion of market-sensitive information.

To assist the IMF in evaluating the publication policy, reader comments are invited and may be sent by e-mail to publicationpolicy@imf.org.

Copies of this report are available to the public from

International Monetary Fund • Publication Services

700 19th Street, N.W. • Washington, D.C. 20431

Telephone: (202) 6237430 • Telefax: (202) 6237201

E-mail: publications@imf.org • Internet: http://www.imf.org

Price: $\$ 15.00$ a copy

\section{International Monetary Fund \\ Washington, D.C.}


This page intentionally left blank

CInternational Monetary Fund. Not for Redistribution 


\section{INTERNATIONAL MONETARY FUND}

\section{CENTRAL AFRICAN REPUBLIC}

\section{Selected Issues and Statistical Appendix}

Prepared by a staff team consisting of Mr. Lewis, Ms. Albertin, Mr. Callier, Ms. Denis,

Mr. Ghura, Mr. Gudmundsson, Ms. Oomes, and Mr. Seck (World Bank)

Approved by the African Department

March 11, 2004

Contents

I. Economic Developments over the Past Decade ……....................................................

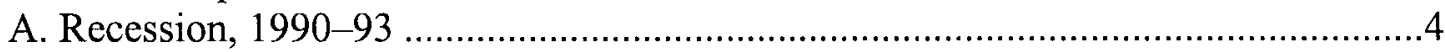

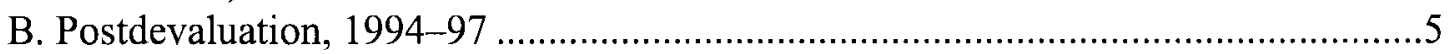

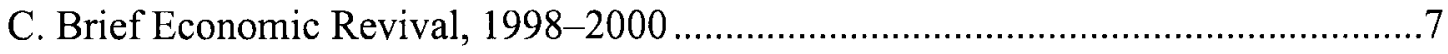

D. Stagnation, PRGF Arrangement and Staff-Monitored Program, 2001-02 ............10

II. The Financial Sector in the Central African Republic ................................................14

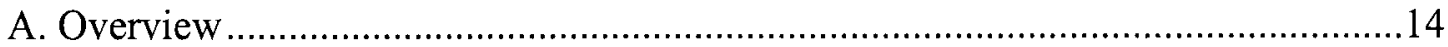

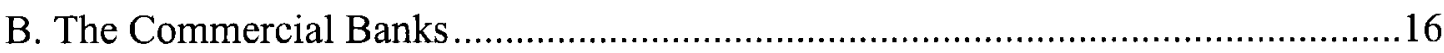

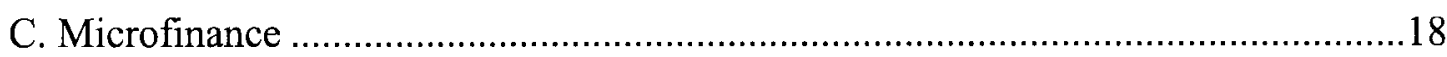

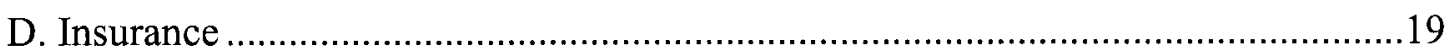

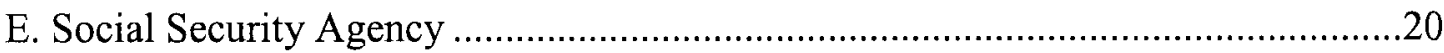

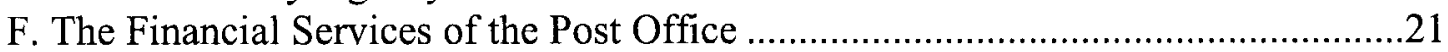

G. Summary and Conclusions........................................................................21

III. Regional Integration: The Case of the Central $\Lambda$ frican Republic ..................................23

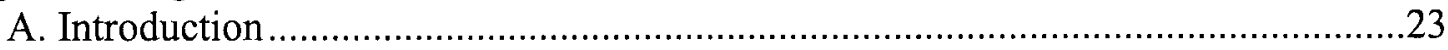

B. The CEMAC Customs Union Reform: An Overview .....................................24

C. The Implementation of the CEMAC Reform in the C.A.R.: An assessment.........26

D. The Effects of the Trade Reform on C.A.R.'s Trade Performance .....................28

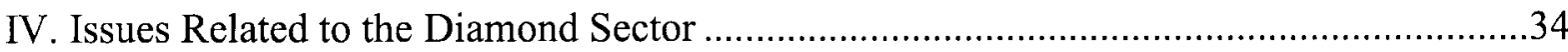

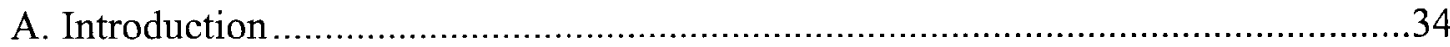

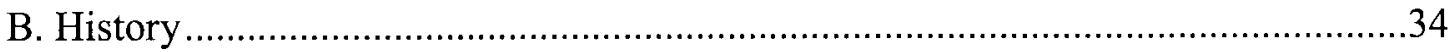

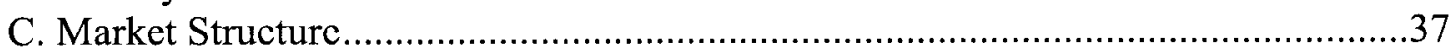

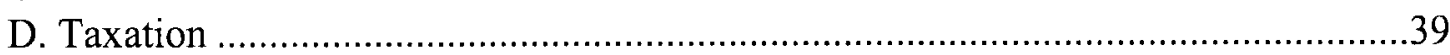

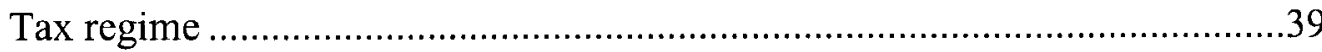

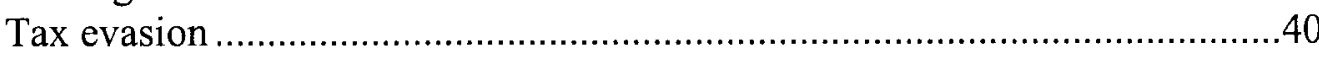


E. Diamond Sector Reforms …….......................................................................

Strengthening artisanal production ..........................................................43

Reducing tax evasion ......................................................................44

Attracting foreign and domestic investment ..................................................46

Appendix: The C.A.R. and the Kimberley Process ........................................50

$\underline{\text { V. Recent Social Developments and Poverty Reduction Focus }}$

Boxes

I.1. Tax and Customs Measures Implemented During 1998-2001

Figures

III.1. Exports and Imports with Non-CEMAC Countries, 1993-2002 …......................30

III.2. $\quad$ Exports and Imports with CEMAC Countries, 1993-2002 (In percent of GDP) ........31

III.3. Exports to CEMAC Countries, 1993-2002 (In percent of total exports) ...................31

III.4. $\quad$ Imports from CEMAC Countries, 1993-2002 (In percent of total imports) ..............32

III.5. Exports to CEMAC Countries, 1993-2002 (In percent of total intra-CEMAC exports).............................................................................

III.6. Imports from CEMAC Countries, 1993-2002 (In percent of total intra-CFMAC imports) ........................................................................ 33

III.7. Trade with CEMAC Countries, 1993-2002 (In percent of total

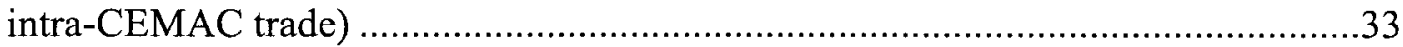

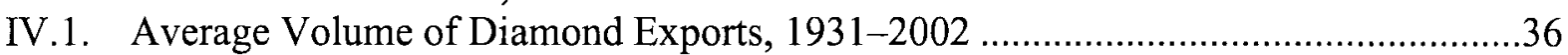

IV.2. Volume of Diamond Exports, 1987-2002 ….....................................................36

Tables

II.1 Domestic Financial Assets Held by the Public, End 2003 Estimates ..........................15

II.2. Financial Intermediation in the Countries of the Two CFA Franc Zones, $2002 \ldots \ldots \ldots .16$

II.3. $\quad$ Financial Deepening Indicators, 1996-2003 .................................................16

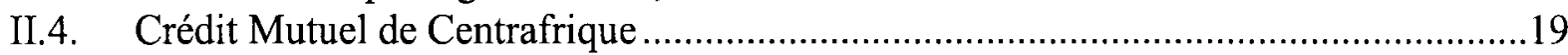

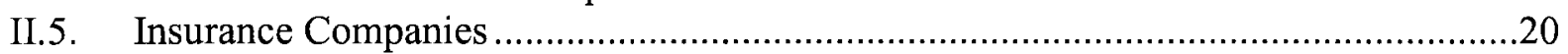

II.6. $\quad$ Social Security: Office Centrafricain de Sécurité Sociale ...................................21

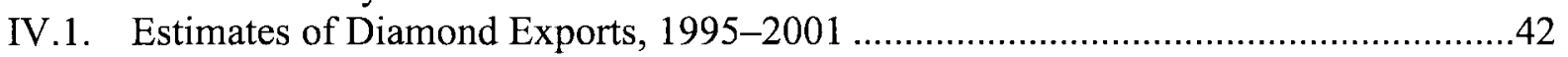

IV.2 Monthly Diamond Exports by Purchasing Bureaus and the BIDB in $2001 \ldots \ldots \ldots \ldots \ldots . .45$

IV.3. Value Added in Jewelry Production .............................................................47

Statistical Appendix Tables

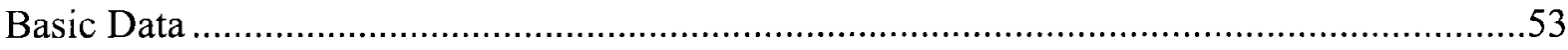

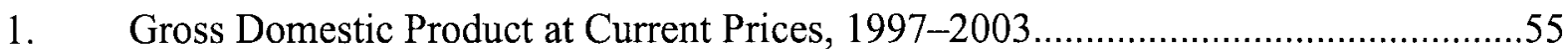

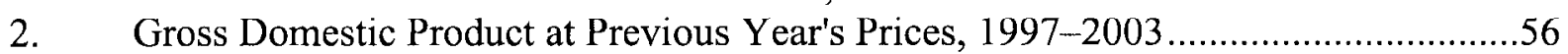

3. $\quad$ Gross Domestic Product, Real Growth Rates, 1997-2003 ...................................57

4. Supply and Use of Resources at Current Prices, 1997-2003...............................58

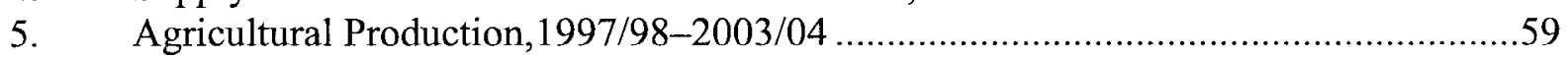

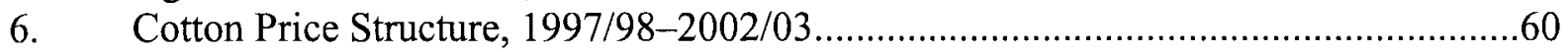

7. Production and Exports of Forestry Products, 1997-2003 …...............................61 


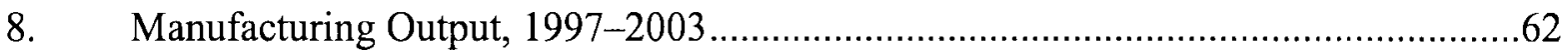

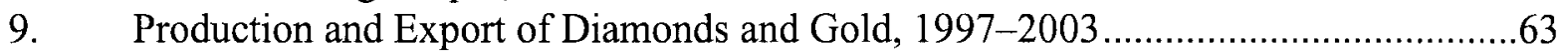

$10 \quad$ Consumption of Oil Products, 1997-2003......................................................64

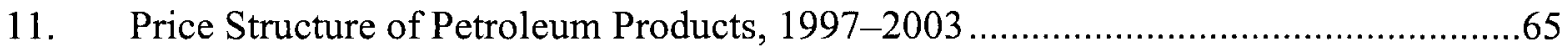

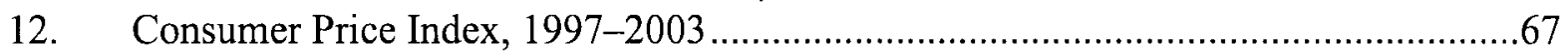

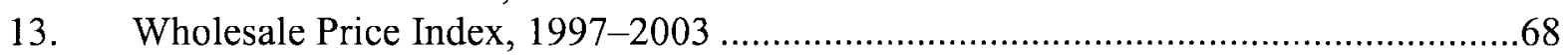

14. Sectoral Composition of Public Investment Program, 1997-2003 ..........................69

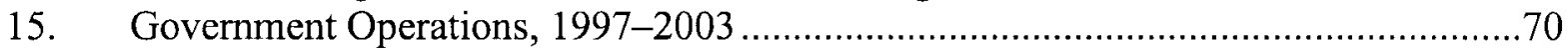

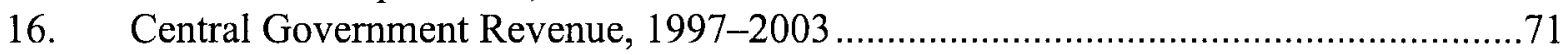

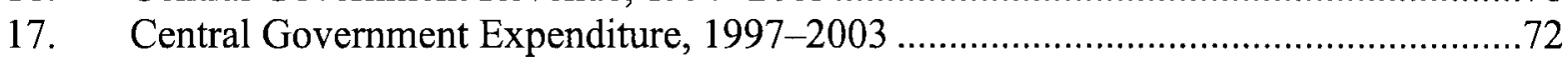

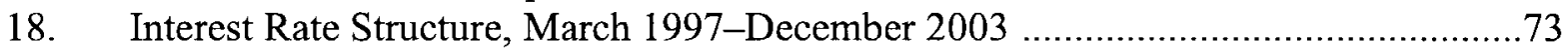

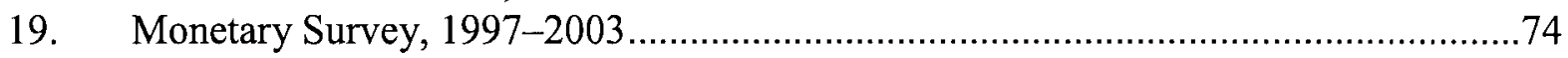

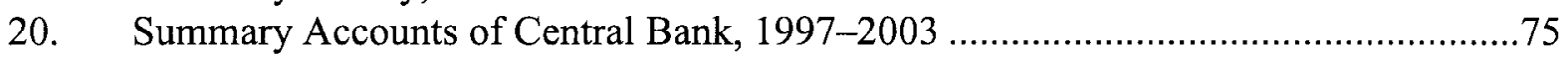

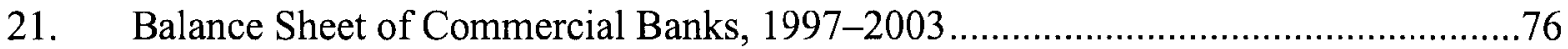

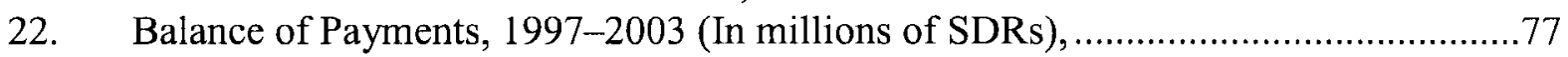

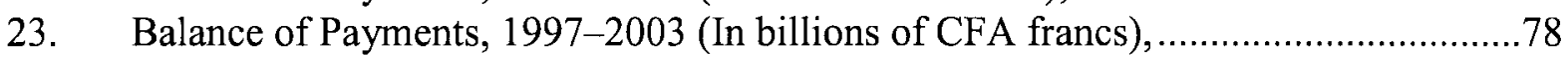

24. Composition of Exports, 1997-2003 ……........................................................79

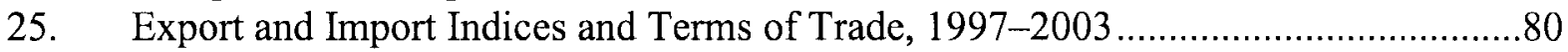

26. Balance of Payments-Selected Components of Services, Income

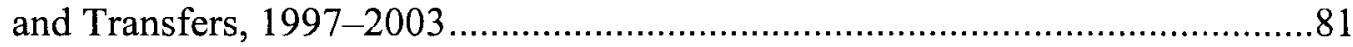

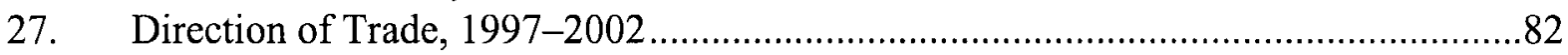

28. $\quad$ External Debt Outstanding and Debt-Service-Service Flows, 1997-2003.................83

29. Debt Service and Arrears on External Public and Publicly Guaranteed Debt, 1997-2003 ……............................................. 84

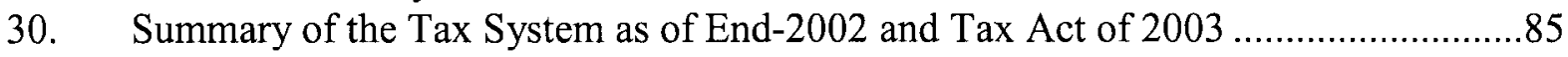




\section{Economic Developments over the PASt Decade ${ }^{1}$}

1. The political situation in the Central African Republic (C.A.R.) since the mid-1990s has been marked by recurrent military disturbances, which have hindered the country's economic development and prospects for financial support from the international community. The vicious cycle of weak governance, tax evasion and inadequate revenue mobilization, and resulting wage arrears to civil servants and military personnel, has fueled the instability. Real GDP per capita is on a declining trend. The fiscal situation is dire. Since 1990, total revenue hovers around the average of 9 percent of GDP, while total expenditure averages 18 percent of GDP. While the deficit has been reduced through time, the adjustment occurred mainly through a sharp contraction of expenditures rather than an increase in revenue, in a way that does not foster the strengthening of the state's ability to provide public goods.

2. This chapter focuses on 1990-2002. The survey is divided into four periods to reflect broadly the phases of relations with the Fund and other donors with respect to program implementation: 1990-93, during which the economy experienced a recession; 1994-97, after the CFA franc devaluation, during which economic growth was interrupted by poor program implementation and mutinies; the period 1998-2000, during which economic growth was somewhat more sustained; and 2001-02, which was marked by two failed coups and military disturbances, and the implementation of the staff-monitored program.

Developments since the conflict that followed the October 2002 failed coup and ended with the coup d'état of March 2003 are covered in detail by the staff report and are not discussed in this chapter.

\section{A. Recession, 1990-93}

3. The period 1990-93 was marked by a severe economic crisis that manifested itself in a 9 percent drop in per capita real GDP (on a cumulative basis) and a tense sociopolitical situation. Economic activity shrank in most areas, particularly in cash crops, forestry, construction and public works, and services. The deterioration in the C.A.R's economic and financial situation during this period can be explained by three main factors. First, there was a sharp deterioration in the terms of trade; the latter fell by some 17 percent during 1988-92. Second, the country underwent a protracted democratization process during which the country's fragile institutions progressively floundered, and the public administration stopped functioning. The fiscal situation worsened, leading to a large accumulation of domestic and external arrears. Social tensions emerged in 1991 when a conflict with the labor movement led to a drawn-out general strike. As the public administration was paralyzed, tax collections fell, depriving the government of resources. In particular, the government could not pay salaries on a regular basis, and arrears were accumulated. Third, the country, as a member of a currency area, suffered from an overvaluation of the CFA franc, which caused a decline in the main exports (coffee, cotton, and timber) and a worsening of the external current account

${ }^{1}$ This section was prepared in 2002 by Dhaneshwar Ghura, and updated by Philippe Callier. 
deficit from about $4 \frac{1}{2}$ percent on average per year during 1987-89 to about 7 percent per year on average during 1990-93.

4. The social unrest and political turmoil preceding the democratization process which culminated in the election to the presidency of Mr. Patasse in 1993 and the disappointing macroeconomic performance impeded the government's efforts to strengthen financial management and reduce imbalances. ${ }^{2}$ Total government revenue declined from 11 percent of GDP in 1990 to 7.9 percent in 1993, owing to the failure to implement most of the revenueboosting measures envisaged in successive budget laws; a surge in tax evasion and fraud; prolonged strikes; and a rapid deterioration in staff efficiency because of the nonpayment of salaries. In response to the decline in revenue, the authorities cut both current and capital expenditures. Nonetheless, the cut in expenditure was not in line with the reduction in revenue and the fiscal deficit deteriorated by about $2 \frac{1}{2}$ percentage points of GDP on average between 1986-89 and 1990-93. The increased deficit was financed from two main sources: the domestic banking system and the accumulation of domestic and external arrears.

5. The fiscal difficulties undermined the civil service throughout this period. Public employees worked only sporadically, and, by the end of 1993, were owed about one year in back pay. Many government expenditure controls and procedures were abandoned; most public schools closed; and government arrears on external and domestic payments had risen significantly.

6. Throughout the late 1980s and early 1990s, the government, constrained by the C.A.R.'s membership in a common currency area, attempted to follow a strategy aiming at restoring the competitiveness of the C.A.R. and growth through internal adjustment measures. This strategy consisted mainly of maintaining the fixed common peg, attempting to reduce the fiscal deficit through increases in tax rates and cuts in the wage bill, and attempting to restore external competitiveness by reducing domestic costs and restructuring public enterprises, including in the cotton and coffee sector. Nevertheless, given the magnitude of the macroeconomic imbalances, it became clear by end-1993 that strategies based exclusivcly on internal adjustment would not be sufficient to put the economy back on a sustainable track of economic recovery. The internal adjustment strategy alone was unable to restore external competitiveness, as nominal domestic prices (including wages and producer prices) showed considerable downward rigidity. In particular, it was not possible to cut the wage bill significantly in relation to GDP, and transfers and subsidies increased (instead of declining).

\section{B. Postdevaluation, 1994-97}

7. Given the inability of internal adjustment strategies alone to revive economic

\footnotetext{
${ }^{2}$ Since gaining independence in 1960 , the C.A.R. has been marred by recurrent political instability and social unrest. In 1981, Mr. Kolingba overthrew President Dacko, who had ousted Emperor Bokassa in 1979.
} 
performance in the countries of the CFA franc zone, the C.A.R., in collaboration with other member countries of the zone, devalued its currency by 50 percent in January 1994 . With a view to complementing the government's adjustment efforts, a 12-month Stand-By Arrangement was approved in March 1994. The primary objectives included further fiscal tightening, as well as the implementation of structural reforms related to the reorganization and downsizing of the civil service, privatization of public enterprises, bank restructuring, and the liberalization of domestic prices and interest rates.

8. Economic and financial developments at the outset of the 1994 program were mainly influenced by the adjustment of the CFA franc parity and normalization of the political and social situation. After four years of decline, real GDP recovered in 1994. This primarily reflected the positive impact of the January 1994 devaluation of the CFA franc on the country's compctitive position, which had becn continuously croding since the mid-1980s. Given the completion of structural reforms in the export sectors of cotton and, to a lesser extent, coffee, the economy was in a favorable position to take full advantage of the sharp rise in the world market price for these commodities. Moreover, the return to greater social and political stability following the democratic election of a president and the formation of a new government in the fall of 1993 restored conditions that were overall favorable to recovery. The public administration started functioning again, as civil servants returned to work and regular current salary payments were resumed by the government.

9. Thus, the improved competitiveness resulting from the change in parity and the accompanying structural measures, together with a strengthening of commodity prices in world markets, boosted the output of the tradable goods sector. In particular, cotton and timber production grew rapidly, neglected coffee plantations were rehabilitated, and livestock exports to neighboring countries rose sharply. While export volume rose by more than 20 percent during 1993-97 (on a cumulative basis), import volume growth decelerated, owing to the higher prices of tradable relative to nontradable goods. The current account balance improved by about 2 percentage points of GDP on average between 1990-93 and 1994-97. The economy also benefited from the regular payments of salaries, which boosted domestic demand and output.

\section{Notwithstanding these positive outcomes, fiscal performance under the 1994 Stand-} By Arrangement was weak, and the program veered off track. Several of the targets for endJune 1994 were not met, including the performance criteria on net bank credit to the government, cash payment of arrears, and nonaccumulation of new arrears, as well as the quantitative benchmarks on government revenue and the wage bill. The implementation of many revenue-enhancing measures was delayed, while expenditure controls were ineffective. The overall fiscal deficit increased by 1 percentage point of GDP between 1993 and 1994. The financing of the deficit was complicated by a shortfall in external financial assistance, which ceased altogether once the program went off track. As a result, new external arrears were accumulated, and little headway was made in clearing domestic arrears.

11. To correct the slippages in the fiscal area, the government adopted a set of measures that eliminated the primary deficit in 1995 . On the revenue side, these measures included an increase in the turnover tax rate, a reduction in tax exemptions, and increased contributions 
from the state-owned oil company (PETROCA). Accordingly, government revenue rose by 2 percentage points of GDP to some 9 percent in 1995. On the expenditure side, the authorities strengthened control over government expenditure, and primary spending fell by 1.3 pcrcentage points of GDP, to 9 percent. The overall fiscal deficit, on a commitment basis, was reduced by about $2 \frac{1}{2}$ percentage points of GDP to about 11 percent. However, in the absence of a formal Fund-supported program, the C.A.R. did not benefit from external financial assistance other than for investment projects and the debt relief granted in 1994 under the auspices of the Paris Club. Hence, the government's financing needs were largely covered by a further accumulation of arrears on external and domestic payments.

12. In spite of the progress achieved in 1995, for the period 1994-97 as a whole revenue performance was weak; total revenue fell by about $1 \frac{1}{2}$ percentage points of GDP between 1990-93 and 1994-97. In an effort to consolidate the fiscal situation, the government had to drastically cut expenditures. Total primary expenditure declined by 6 percentage points of GDP on average between 1990-93 and 1994-97, and the overall budget deficit declined by about 4 percentage points on average between these two subperiods. The government's effort to consolidate the fiscal situation helped to contain the inflationary pressures from the devaluation, which, in turn, enabled the country to largely restore the gains in external competitiveness that were obtained following the devaluation. Real GDP increased by about 11 percent during 1993-97 (on a cumulative basis), but this was not sufficient to raise per capita real GDP.

13. Notwithstanding its efforts to consolidate the fiscal situation, the government was no longer able to pay wages on a regular basis, including to the military personnel. The ensuing discontent within the army led to three mutinies between May 1996 and January 1997 that deepened the economic and financial crises, and further decreased investors' confidence. The unrest, which was largely localized in Bangui - the administrative and economic capitalhalted most economic activity, shut down the public administration, caused widespread damage and looting, and forced the departure of most foreign technical experts. The destruction of manufacturing industries and large distribution companies in Bangui idled thousands of workers. The government could no longer service its external debt, including to the World Bank and the African Development Bank (AfDB). These events prevented the conclusion of the discussions on a possible Fund-supported program.

\section{Brief Economic Revival, 1998-2000}

14. In the aftermath of the military mutinies in 1996-97, the authorities undertook to restore peace with the help of the international community. At the root of the crisis were ethnic conflicts within the C.A.R. armed forces and the accumulation of salary arrears. The international community intervencd in a variety of interdependent ways. First, an interAfrican intervention force (MISAB) was replaced by UN peacekeeping troops (MNURCA) in April 1998. Second, a large part of the salary arrears accumulated since the late 1980s were paid with French financial assistance to reduce social tensions. Third, in order to address the fundamental security and political problems, the UN opened a peace-building support office (BONUCA), which helped develop a restructuring plan for the army and strived to facilitate the dialogue between the party in power and the opposition parties. 
Fourth, with assistance from MINURCA, legislative elections were conducted in November 1998 and presidential elections in September 1999, which observers judged free and fair. MINURCA left in February 2000.

15. With the return of peace in April 1997, the government increasingly turned its attention to the severe domestic financial issues and stepped up its efforts from October 1997 onward with Bank and Fund assistance. To set the stage for the resumption of a formal program with the Fund in 1998, the authorities had already implemented a number of institutional and public finance measures during April-December 1997. The constitution of the Interministerial Committee on Economic and Structural Reforms and its Permanent Technical Committee, in mid-1997, enabled the authorities to strengthen public sector management, especially government finances, as well as to resume laying the groundwork for civil service and public enterprise reform (Box I.1).

16. A three-year arrangement under the Poverty Reduction and Growth Facility (PRGF) (originally the Enhanced Structural Adjustment Facility-ESAF) was approved in July 1998. ${ }^{3}$ The program aimed at halting the deterioration in public finances by reinforcing revenue mobilization and controlling expenditure execution; strengthening macroeconomic management and institutional capacity; and formulating and implementing a prioritized structural reform agenda related to the privatization of nonfinancial public enterprises, and reform of the banking and financial sector, legal and regulatory framework, as well as the civil service.

17. Program implementation was weak, and delays were encountered in completing the first review under the program. Revenue collection fell short of the program target; for this reason as well as delays in the disbursement of external assistance (linked in part to delays in privatizing the petroleum company), the treasury cash position prevented the full settlement of government wage and salaries and external debt service due. In the face of slippages in program implementation, the authorities agreed to take corrective actions. They set revised revenue targets for December 1998 and March 1999, and adopted a series of measures to improve revenuc collection. They also undertook to accelerate the implementation of structural reforms under the ESAF-supported program and to adopt additional measures to reduce the deficit of the national cotton company (SOCOCA).

18. The new government appointed in January $1999^{4}$ made progress in the implementation of the corrective actions, thus providing the basis for the completion of the midterm review discussions. The measures included primarily the following: the significant mobilization of government revenue; administrative measures to strengthen collection

${ }^{3}$ In September 1998, a Paris Club meeting extended debt relief on Naples terms to the C.A.R. In 1999, the World Bank launched the preparation of a Policy Support Project, and IDA approved a Fiscal Consolidation Credit for an amount equivalent to US\$20 million.

${ }^{4}$ Following the legislative elections of November 1998. 
agencies, including completion of an audit of the customs computer systems; payment by the petroleum company of its tax arrears; completion of the inventory of domestic debt and arrears as of end-1997; privatization of one commercial bank (BICA); issuance of the tenders for the privatization of another state bank (UBAC); completion of the closure of all nonfinancial public enterprises and commercial banks that had ceased operations; reinforcement of the framework for the privatization of the petroleum company; and adoption of measures to reduce the deficit of the cotton company.

19. The authorities' efforts to strengthen the fiscal position in 1999 were thwarted by extensive fraud, particularly at the level of customs, as well as expenditure overruns in the run-up to presidential elections. At slightly over 9 percent of GDP, government revenue in 1999 was essentially unchanged from 1998, despite the measures adopted by the authorities to improve tax and customs administration and widen the tax basc. Revenue collection suffered from persistent evasion, especially of customs duties, and a large-scale fraud on petroleum taxes and duties. ${ }^{5}$ The poor results at customs stemmed from weak administrative capacity, outdated computer systems, the evasion of duties and import turnover taxes, and difficulties in recovering tax and duty arrears. In addition, there were disturbances in regional trade owing to civil wars in the Republic of Congo and the Democratic Republic of the Congo (which hampered transit from Brazzaville and Kinshasa), and to transport bottlenecks, owing to the strikes in Cameroon.

20. The international community's assistance in bringing about political stability and establishing a framework for macroeconomic stability had beneficial effects on overall economic performance during 1998-2000, compared with the period 1994-97. Total government revenue increased on average by $1 \frac{1}{2}$ percentage points of GDP between 1994 97 and 1998-2000, while average total expenditure as a ratio to GDP remained unchanged. Within the tight expenditure execution, the government reallocated outlays from current to capital expenditures; thus, current expenditure as a ratio to GDP declined on average by about $1 \frac{1}{2}$ pcrcentage points, while domestically financed capital expenditure increased by the same amount. The overall budget deficit declined by $1 \frac{1}{2}$ percentage points of GDP on average between 1994-97 and 1998-2000. Real GDP grew by an average of about 3 percent during the period 1998-2000, propelled in large part by logging, manufacturing, and construction.

21. Nevertheless, economic activity slowed considerably in 2000 , mainly on account of poor weather, a hike in energy costs, and a strike. The negative impact of rising oil prices

5 A Bangui-based company, SICOTRANS, purchased tax-free petroleum products from PETROCA, the national petroleum company, with the stated intent of re-exporting them to the Democratic Republic of the Congo via a fictitious company named "Zongo-Oil" (Zongo is a small DRC city located across the Oubangui River from Bangui). In fact, the tax-free petroleum products were sold on the local market at a large profit for SICOTRANS. Based on reports prepared by the tax auditors, losses in tax revenue may have reached CFAF 34 billion (0.5 percent of annual GDP) during 1998 and 1999. 
was compounded by a doubling of the transportation costs of petroleum products caused by the shift from river transportation from Kinshasa, Democratic Republic of the Congo (DRC), to road transportation from Douala, Cameroon. ${ }^{6}$ To help cover the higher import and transportation costs, the government raised the supplier prices of petroleum products to by 33-44 percent in mid-October 2000. However, taxes were also reduced substantially to limit the increase in retail prices, especially for kerosene and cooking oil. In October 2000, the labor unions called a general strike, which paralyzed the public administration for months.

\section{Stagnation, PRGF Arrangement and Staff-Monitored Program, 2001-02}

22. The Fund's Board approved a second annual program under the PRGF arrangement on January 10, 2001. The program aimed at strengthening economic management and, in particular, moving toward fiscal sustainability. A key objective was to raise the revenue-GDP ratio from 8.9 percent in 2000 to 9.8 percent in 2001 . This was to be achieved through the implementation of measures to strengthen tax administration, and legal and regulatory changes to streamline and improve the tax system. Reflecting primarily the revenue mobilization effort, but also a slight decrease of primary expenditures (excluding foreignfinanced investment) as a percentage of GDP, the primary budget balance was projected to increase from 0.4 percent of GDP in 2000 to 1.1 percent of GDP in 2001.

23. Within a generally unfavorable domestic climate (with 2001 real GDP growth down to 0.3 percent), the authorities undertook a number of measures aimed at strengthening economic management and governance. In particular, a value-added tax (VAT) was introduced; the scope for exemptions from VAT was narrowed; a new organizational structure was introduced for the tax and customs administration; a committee to review and revise, when necessary, the petroleum price structure became fully operational; and the liquidation of the state-owned petroleum company (PETROCA) was completed. In addition, the provisions of the regional Organization for the Harmonization of Business Law in Africa (OHADA) treaty to reinforce the rule of law, combat corruption, and harmonize business law became effective.

24. However, in the context of stagnating economic growth (compared with the program projection), there were significant slippages in other aspects of program implementation. At end-March 2001, the time of the first program review, revenue collection was more than 10 percent short of the program target. Moreover, after having settled two months of salary arrears in January and February, the authorities fell again short of their wage payments commitments in March, as well as on the schedule agreed under the program to clear arrears to external creditors, notably the AfDB. At the same time, in March, the authorities used about CFAF 2 billion, equivalent to one month of wage payments, to clear arrears to the national cotton company (SOCOCA). To a large cxtent, these payments were financed with a

\footnotetext{
${ }^{6}$ The decision to suspend river transportation was taken by the river transport company in May 2000 after several attacks on its boats by DRC rebels. River transportation resumed gradually at the end of 2001 .
} 
loan from the Libyan Arab Foreign Bank, contracted on nonconcessional terms, which was not envisaged under the program.

25. In the second quarter of the program, the revenue collection effort weakened considerably, and the government stopped servicing external debt and made recourse to an already overstretched banking system to cover domestic expenditure commitments. At endJune, government revenue was 26 percent short of the program target, none of the program's quantitative and structural benchmarks were met, and it was clear that the authorities could not bring the PRGF-supported program for 2001 back on track. During the third quarter of 2001, revenue collection, while recovering slowly, remained significantly below the targets set under the PRGF-supported program. With the government cut off from any additional domestic or external financing sources, another month of wage payments arrears was accumulated in September 2001.

26. In October 2001, the C.A.R. authoritics asked the IMF staff to help them in monitoring their adjustment effort by means of a six-month staff-monitored program (SMP) covering the period October 2001 to March 2002. Performance during the first quarter of the SMP (October-December 2001) was poor. The primary budget surplus fell short of the target by CFAF 3.9 billion, owing entirely to lower-than-programmed cash revenue. ${ }^{7}$ Also, net bank claims on the government exceeded the program ceiling. Moreover, the program adjuster was not fully respected, as part of the available resources was devoted to cash settlements of domestic nonwage arrears (including pensions), while wage arrears were permitted to accumulate. As regards the structural benchmarks that should have been met by end-December 2001, compliance with the VAT was verified for 47 rather than 150 large companies, while the study on the economic impact of the trade regime for sugar imports was not completed.

27. Performance improved during the second quarter of the SMP (January-March 2002), contributing to a catching up on the shortfalls registered during the last quarter of 2001. In particular, fiscal revenues largely exceeded estimates and current expenditures were contained within the target. Wages and salaries were below target, due to arrears accumulation in January and February, but that trend was reversed in March and salary payments resumed normally. Capital spending by the government was higher than projected, owing to a program of buildings rehabilitation subsequent to the military events of November 2001. Revenue performance was sustained during the second and third quarters of 2002, and continued to exceed targets agreed with the Fund staff. Tax collection was boosted by enhanced control of large enterprises (VAT receipts) and improved surveillance of the borders (customs receipts). For the same period, current expenditures were higher than targeted, owing to the payment of some salary arrears and higher spending on goods and services. Spending on goods and services exceeded the target agreed with the staff in every

${ }^{7}$ Part of this underperformance was caused by a shortfall in rental income from the Mission of the United Nations in the Democratic Republic of the Congo (MONUC), a factor outside the control of the authorities. 
quarter of 2002. Extra borrowing from the banking sector helped to face the payment of those arrears. Overall, efforts on the revenue side started to bear fruit, while, in contrast, expenditure control needed tightening.

28. Although the revenue target was met again during the fourth quarter, thanks to an improved tax yield in the forestry sector and sustained VAT control efforts, expenditures, particularly security and defense expenditures, increased sharply. For the year as a whole, in spite of the contraction of real GDP (by 0.6 percent), total revenue increased by 1.9 percent of GDP. However, expenditures increased faster (by 2.6 percent of GDP on a commitment basis), and new arrears accumulated (by an additional 2.9 percent of GDP).

29. The coup attempt of October 2002 disrupted the fragile fiscal consolidation achieved under the SMP. As documented in the staff report, the military conflict that ensued, and ended with the coup of March 2003, led to a collapse of revenue and a sharp deterioration of the public finance situation in the context of a pronounced contraction in formal sector activity in 2003. 


\section{Box I.1. Tax and Customs Measures Implemented During 1998-2001}

The C.A.R. has faced serious difficulties in raising government revenue collection in recent years. During 1994-2001, the revenue-to-GDP ratio was about $81 / 2$ percent, far below that observed in other developing countries. The low revenue stems from the large share of subsistence agriculture in total GDP (about 30 percent); widespread tax evasion, especially in the diamond sector; and deep-seated weaknesses in the tax and customs administration. The authorities took a series of measures to address these weaknesses in the context of the Central African Economic and Monetary Community (CEMAC) tax reform, as well as with technical assistance from the Fund. Some key measures adopted from 1998-2001 include the following:

- reduction of the scope of tax exemptions; suspension of all exemptions not provided for by the CEMAC legislation; prohibition of all ad hoc tax and customs exemptions - no exemption can be granted unless it has a legal basis and has been approved by the Minister of Finance;

- increase in turnover tax and excise duty for tobacco;

- introduction of Antwerp diamond market prices as reference prices for diamond export taxation;

- institution of a minimum turnover for diamond-purchasing bureaus, equivalent to US\$1.25 million per month;

- streamlining of export taxation, with a consolidation of the export turnover tax into a single export tax (droit de sortie);

- upward adjustment of selected business license fees;

- systematic issuance of real estate tax assessments;

- finalization of the update of the computer system used at the main customs frontier offices; upgrade of the main computer systems used at customs (hardware and software);

- introduction of a new organizational structure for the tax and customs administration;

- development of closer links between customs administrations in the C.A.R. and in Cameroon, to monitor closely shipments in transit from Douala to Bangui;

- cross-checking of customs declarations with certificates issued by a private preshipment control company;

- strengthening of collection efforts for tax arrears by the Tax Directorate and the treasury;

- creation of a large taxpayers' unit;

- intensification of the use of the single taxpayer identification number, including for the informal sector;

- introduction of a single-rate VAT system in early 2001;

- narrowing of the scope for exemptions from VAT; and

- strengthening of the verification of compliance with the VAT system by large enterprises. 


\section{The Financial Sector in the Central African Republic ${ }^{8}$}

\section{A. Overview}

30. The financial sector of the Central African Republic (C.A.R.) comprises the national branch of the Banque des Etats de l'Afrique Centrale (BEAC)-the regional central bank that also covers five other CEMAC countries-three commercial banks, a microfinance institution, two postal financial institutions (a postal savings bank and postal checking center), two insurance companies, two general insurance agents, a mutual insurance association, and a social security institution. There are no active organized financial markets, and no securities are traded. There are neither leasing companies nor term lenders. The regional supervisor of the banks and microfinance institutions is the Banking Commission of Central Africa (COBAC). ${ }^{9}$

31. The sector is still largely underdeveloped. Besides the illiquid claims arising from the various types of arrears of the state, the single most important domestic financial asset held by the public is currency, with deposits in commercial banks a distant second, implying that the central bank, not the commercially driven deposit banks, is the dominant financial intermediary in the C.A.R. (Table II.1). The financial sector mobilizes little savings, allocates little capital, and provides only the most elementary payment and risk management services. This state of affairs points toward the weakness in the institutional underpinnings of financial sector activity, and specifically in the mechanisms for the enforcement of contracts and the monitoring of borrowers' performance. According to bankers, slow and unpredictable judiciary processes in the C.A.R. hinder the collection of claims and increase the cost of financial intermediation. A comparison with the countries of the West African Economic and Monetary Union (UEMOA) and the Central African Economic and Monetary Community (CEMAC) indicates that, within the two CFA franc zones, the C.A.R. has the lowest ratio of deposits to GDP, as well as the highest share of currency in M2 (Table II.2).

32. Financial deepening is not occurring in C.A.R. From 1996 onwards, the year during which the nominal money stock reached a historical peak, to 2003, the money stock fell by 21 , percent while nominal GDP rose by 35 percent. Money as a percentage of GDP, a crude indicator of financial deepening, fell from 24 percent in 1996 to 14 percent in 2003, in spite of the return to price stability after the devaluation of the CFA franc in 1994 . Over the

\footnotetext{
${ }^{8}$ This section was prepared by Philippe Callier. It draws on information received in the context of the Article IV consultation discussions and on an unpublished World Bank report on the financial sector of the C.A.R. prepared in 2003. End-2003 estimates are based on provisional November and December data and are liable to revision.

${ }^{9}$ The governor of the BEAC is, ex officio, president of the COBAC. The board of directors of the BEAC may modify the terms of the convention establishing the COBAC (a unanimous decision is required). The $\mathrm{BEAC}$ is mandated to ensure the functioning of the COBAC on the BEAC's own budget.
} 
same period, deposits in the commercial banks as a percentage of GDP fell steadily from 4.3 percent to 3.3 percent in 2000 , but recovered to about 4 percent thereafter (Table II.3). The capacity of the banks to mobilize additional deposits over the past three years, in very difficult circumstances, may have been due in part to the completion of the restructuring and privatization of 2 of the three banks in 1999, which included recapitalization.

Table II.1: Domestic Financial Assets Held by the Public, End 2003 Estimates

\begin{tabular}{|l|c|}
\hline \multicolumn{1}{|c|}{ Nature of asset } & $\begin{array}{c}\text { Billions of CFAF } \\
\text { (except if indicated otherwise) }\end{array}$ \\
\hline Claims on Financial Intermediaries & 71.4 \\
\hline Currency outside banks & 33.5 \\
\hline Deposits in commercial banks (including & 10.9 \\
\hline deposits of public institutions) & 4.5 \\
\hline Of which: terms and savings deposits & 2.2 \\
\hline Technical reserves of insurance companies (2001) & 1.0 \\
\hline Members accounts, CMCA 1/ & 0.5 \\
\hline Pour mémoire: Liquidity held by CMCA & 0.1 \\
\hline Deposits at the Savings Postal Bank & \\
\hline Deposits of the public at the Postal Checking Center & 93.2 \\
\hline Arrears of the State & 61.1 \\
\hline Suppliers & 11.5 \\
\hline Salaries & 2.2 \\
\hline Pensions & 8.7 \\
\hline Scholarships & 1.1 \\
\hline Arrears of the Social Security Office & \\
\hline Outstanding fiscal advances & \\
\hline
\end{tabular}

1/ The liquidity held by the CMCA in currency (CFAF 0.1 billion) or in deposit with the banks (CFAF 0.9 billion) is already included in the money stock, so that the net contribution of the CMCA to the claims of the public on the financial intermediaires is CFAF 1.2 billion. 
Table II.2. Financial Intermediation in the Countries of the Two CFA Franc Zones, 2002 (In percent)

\begin{tabular}{|l|c|c|}
\hline & Deposits/GDP & Currency outside banks/M2 \\
\hline Benin & 16.6 & 33.5 \\
\hline Burkina Faso & 16.7 & 21.0 \\
\hline Cameroon & 13.1 & 24.9 \\
\hline Central African Republic & $\mathbf{3 . 8}$ & $\mathbf{7 3 . 8}$ \\
\hline Chad & 5.1 & 62.1 \\
\hline Congo & 6.8 & 44.2 \\
\hline Côte d'Ivoire & 14.8 & 47.9 \\
\hline Equatorial Guinea & 4.7 & 26.2 \\
\hline Gabon & 14.0 & 22.0 \\
\hline Mali & 15.9 & 39.7 \\
\hline Niger & 7.0 & 28.8 \\
\hline Senegal & 21.7 & 19.8 \\
\hline Togo & 16.5 & 27.3 \\
\hline
\end{tabular}

Table II.3. Financial Deepening Indicators, 1996-2003 (In percent)

\begin{tabular}{|c|c|c|c|c|c|c|c|c|}
\hline & 1996 & 1997 & 1998 & 1999 & 2000 & 2001 & 2002 & $\begin{array}{c}2003 \\
\text { Estimates }\end{array}$ \\
\hline M2/GDP & 24.4 & 20.6 & 16.1 & 16.5 & 16.2 & 15.5 & 14.4 & 14.3 \\
\hline Deposits*/GDP $^{1}$ & 4.3 & 4.1 & 3.7 & 3.8 & 3.3 & 3.8 & 3.8 & 4.1 \\
\hline
\end{tabular}

${ }^{1}$ Excluding deposits of the state.

\section{B. The Commercial Banks}

33. The three commercial banks operating in the C.A.R. are the Banque Internationale pour la Centrafrique (BICA), the Banque Populaire Maroco-Centrafricaine (BPMC), and the Commercial Bank Centrafrique (CBCA). The government holds a minority participation in each of the three banks. ${ }^{10}$ The BICA has the biggest share of deposits (40 percent), while the

${ }^{10}$ The capital of BICA, which replaced the Banque Méridien BIAO (BMBCA) following the failure of the Méridien Group, is now held by the Belgolaise (35 percent), the BICA's Chairman of the Board (28 percent), COFIPA, a group of African business people (15 percent), the government and public enterprises (10 percent), and private central Africans (12 percent). The Belgolaise sold its share but the transaction was rescinded by the COBAC which has the responsibility to clear such deals after assessing the suitability of prospective major shareholders (the Belgolaise ceased however to provide the managing director and cancelled its line of credit to BICA). The capital of the CBCA, which was created when the Union Bancaire en Afrique Centrale (UBAC) was sold to the Fotso Group of Cameroon, is held by the Fotso Group (51 percent), private central Africans ( 39 percent) an the 
CBCA has the biggest market share in term of credits ( 44 percent). The BPMC is the smallest bank, with a 23 percent market share in terms of both deposits and credits.

34. In light of the drying up of external assistance in the last two years, the government has increasingly resorted to financing from the domestic commercial banks, and public institutions have run down their deposits with banks. As a result, the government weighs heavily on those banks (at end-December 2003, credit to the public sector stands at 29 percent of the total domestic credit of commercial banks), and the banking sector is now facing a liquidity crisis. To alleviate this problem, the governor of the BEAC has exempted the banks in the C.A.R. from the reserve requirements since May 22, 2003. " Although the banking system of the CEMAC as a whole is facing excess liquidity, the de facto fragmentation of the interbank money market and the perceived country risk attached to the C.A.R. inhibit a reallocation of liquidity to the C.A.R. banks. ${ }^{12}$

35. The banking sector is presently under considerable strain. Globally, for the two largest banks, the ratio of doubtful loans to gross credits stood at about 34 percent at end2003. According to the banks, provisions cover on average 90 percent of the doubtful loans. ${ }^{13}$ Of the three commercial banks, BICA is classified by the COBAC as being in a very critical financial situation, with none of the prudential ratios based on net worth being met. BICA urgently needs to be recapitalized. To increase the equity eligible to meet the solvability ratio, it needs also to recover from major shareholder credits far in excess of what the regulations allow. ${ }^{14} \mathrm{CBCA}$ is in a moderately fragile financial situation and does not meet the required liquidity ratio. ${ }^{15} \mathrm{BPMC}$ is classified as being in a sound financial situation.

government (10 percent). The capital of the third bank, the BPMC, created in 1991, belongs to the group of the Crédit Populaire du Maroc, a major public sector institution in Morocco (62.5 percent), and the Central African state (37.5 percent).

${ }^{11}$ Since February 2003, the required reserve ratios stand at 7.75 percent of demand deposits and 5.75 percent of term deposits for countries classified as countries with satisfactory liquidity (Cameroon, Congo, and Equatorial Guinea). For the countries with a fragile liquidity position (C.A.R., Chad, and Gabon), the corresponding ratios are 5 percent and 3 percent.

12 In response to this excess liquidity in the region as a whole, BEAC increased the required reserve ratios in February 2003, accepted deposits from banks under the reverse auction scheme, and, in December 2003, reduced its interest rate on auctions from 6.3 percent to 6.0 percent.

${ }^{13}$ A credit for which a payment is overdue by more than three months (or six months for real estate credits) is defined as doubtful. Provisioning of doubtful claims guaranteed by the state is optional.

${ }^{14}$ The remaining balance on this loan is CFAF 600 million, without the interests and charges. 


\section{Microfinance}

36. The microfinance sector in the C.A.R. comprises three types of organizations: savings and credit cooperatives; non governmental organizations (NGOs) engaged in microfinance in conjunction with other services; and donor projects with a credit component. The sector has been adversely affected by the political and military disturbances of the recent past. Of a total of 60 primary units known to exist in 1999, only 44 are still in existence.

37. The single most important organization active in the sector is the Crédit Mutuel de Centrafrique (CMCA), a federation of 18 primary caisses, which account for 41 percent of the primary units of the sector, between 95 to 98 percent of the savings and credit transactions, and 80 percent of the members (Table II. 4 summarizes the business profile of the CMCA). The CMCA was created in 1994, and grew rapidly up to 2000 , when the membership's deposits reached CFAF 2.2 billion, a level close to that observed at the end of 2003. Credits also increased rapidly to reach a stock of CFAF 600 million in 2000. After a sharp reduction in 2001 and 2002, the lending activity recovered in 2003 . With doubtful credits representing 8.5 percent of the total outstanding, the CMCA appears better managed than most other microfinance institutions. ${ }^{16}$ In addition to savings and credit products, the CMCA offers some basic payment services for the payment of wages for the workers of 17 private enterprises.

38. The CMCA is not yet self-sustained, as it still receives subsidies and does not break even. ${ }^{17}$ It also suffered from destruction and looting during the recent conflict. It estimates the cost of reconstruction at CFAF 70 million (16 percent of 2002 gross revenue).

39. In April 2002, the COBAC issued a prudential framework applicable to the microfinance sector, and the new regulations are being put in place. According to this framework, all microfinance institutions will be required to obtain a license (agrément) from the Ministry of Finance, subject to the clearance of the COBAC which retains responsibility

The nominal capital of the bank is CFAF 1.5 billion.

15 The liquidity ratio is a weighted average of short-term assets in percentage of a weighted average of short-term liabilities. The required minimum liquidity ratio is 100 percent.

${ }^{16}$ For the 19 savings and credit caisses created in the context of UNDP's project in Support of the Fight against Poverty, doubtful credits amount to 79 percent of the total outstanding credits (of CFAF 19 million). Since the end of the donor support, a part of the savings of the membership is at risk, given the fact that the operating costs absorb part of the resources of the caisses.

${ }^{17} 2003$ subsidies include support from the French Development Agency and from the Centre International du Crédit Mutuel. 
for prudential supervision. ${ }^{18}$ The Ministry of Finance established in December 2002 a special unit to fulfill its new responsibility of granting licenses. A professional association of microfinance institutions is to be established. The various organizations have two years to meet the new institutional requirements and prudential ratios.

Table II.4. Crédit Mutuel de Centrafrique (end-December 2003)

\begin{tabular}{|c|c|}
\hline Number of primary branches & 18 \\
\hline Of which, in Bangui & 10 \\
\hline Membership (persons) & 48,424 \\
\hline Deposits (CFAF millions) & 2,247 \\
\hline Average balance (CFA francs) & 39,303 \\
\hline In US dollars & 73.6 \\
\hline Credit outstanding (CFAF billions) & 0.722 \\
\hline Number of credit files & 1.874 \\
\hline Average (CFA francs) & 385,272 \\
\hline In US dollars & 722 \\
\hline Doubtful credits (CFAF millions) & 61 \\
\hline In percent age of total outstanding & 8.45 \\
\hline Subsidies (CFAF millions) & 56 \\
\hline Net results (CFAF millions) & -47 \\
\hline
\end{tabular}

\section{Insurance}

40. The insurance sector comprises two insurance companies and two general agents. ${ }^{19}$ The two companies are the Union Centrafricaine d'Assurance et de Réassurance (UCAR), which is the largest of the two (63 percent market share in 2001), and the Union des Assurances Centrafricaines (UAC). Coverage for automobile, fire, transport and other risks is available, but no term life insurance is offered. ${ }^{20}$ While these insurers suffered from the unfavorable environment in 2001 and 2002, they were still registering profits (TableII.5).

41. The prudential supervision of the insurance sector is the responsibility of the Conférence Interafricaine du Marché de l'Assurance (CIMA). This regional regulator has not conducted an on-site inspection of the insurance companies in the C.A.R. in the last six years, an issue requiring immediate attention.

18 Institutions with less than CFAF 50 million $(\$ 94,000)$ will not be subjected to on-site
inspection.

${ }^{19}$ No additional information is available on the general agents.

${ }^{20}$ UCAR offers, however, a life insurance product that is a complementary pension scheme. 
Table II.5. Insurance Companies

(Millions of CFA francs, 2001)

\begin{tabular}{|l|c|}
\hline Net worth & 1,088 \\
\hline Technical provisions & 4,491 \\
\hline Premium received & 1,433 \\
\hline Operating profits & 162 \\
\hline
\end{tabular}

Source: Unpublished World Bank report on the financial sector of the C.A.R., 2003.

\section{E. Social Security Agency}

42. The social security agency, Office Centrafricain de Sécurité Sociale (OCSS), provides social security protection to private sector and public enterprise workers as well as workers employed by the state outside the civil service. Contributions amount to 20 percent of wages (18 percent paid by the employer and 2 percent paid by the worker). The three branches of responsibility of the OCSS are the family allowances, the workmen's compensation scheme, and pensions. As of the end of 2003, the OCSS covers 3,551 employers with 27,034 employees. Benefits accrue to 11,234 beneficiaries. Quarterly benefits (of which almost three-fourths are pensions) amount to CFAF 432 million, an amount roughly in line with contributions due. ${ }^{21}$

43. The financial situation of the OCCS is in dire straits. The disastrous state of the finances of the public sector (and some private sector enterprises as well) led to the nonpayment of contributions, and the OCCS itself has large arrears to beneficiaries, and further arrears accumulation is likely (Table II.6). At end-December 2003, arrears in benefit payments amounted to CFAF 8.7 billion (of which CFAF 5 billion correspond to unpaid pensions). Contributions arrears amounted to CFAF 31.0 billion and other frozen claims on the public sector amounted to CFAF 5.5 billion. The looting and destruction due to the recent conflict — estimated, provisionally, at CFAF 610 million-further undermined the work of OCCS.

${ }^{21}$ There have been no official financial statements since 1997. In 1997, globally, the OCSS was registering a deficit. The family allowances and workmen's compensation branches generated surpluses while the pension branch recorded a deficit. No actuarial study of the pension scheme has been done over the past 15 years. 
Table II.6. Social Security: Office Centrafricain de Sécurité Sociale (Millions of CFA francs)

\begin{tabular}{|l|c|c|c|}
\hline \multicolumn{1}{|c|}{ Branch } & $\begin{array}{c}\text { Quarterly benefits } \\
\text { as of January 2004 } \\
\text { (CFAF millions) }\end{array}$ & $\begin{array}{c}\text { Arrears } \\
\text { as of Dec. 31, 2003 } \\
\text { (CFAF millions) }\end{array}$ & $\begin{array}{c}\text { Arrears } \\
\text { (in multiple of } \\
\text { quarterly benefits) }\end{array}$ \\
\hline Family allowances & 95.2 & $3,672.6$ & 38.6 \\
\hline $\begin{array}{l}\text { Workmen's } \\
\text { compensation }\end{array}$ & 20.7 & 12.1 & 0.6 \\
\hline Pensions & 316.3 & $5,033.4$ & 15.9 \\
\hline Total & $\mathbf{4 3 2 . 2}$ & $\mathbf{8 , 7 1 8 . 1}$ & $\mathbf{2 0 . 2}$ \\
\hline
\end{tabular}

\section{F. The Financial Services of the Post Office}

44. The post office is responsible for the postal savings bank (the Caisse Nationale d'Epargne, CNE), whose liabilities are savings deposits recorded in passbooks, and a postal checking center (the Centre des Chèques Postaux, $\mathrm{CCP}$ ), whose liabilities are current account deposits. The resources mobilized by these two units are channeled to the Treasury to finance general expenditures. The CNE, with liabilities to depositors amounting to CFAF 500 million, is currently inactive. The CCP has a little over 3,000 accounts, mainly held by individual depositors (but also by the Treasury and public enterprises). The deposits of the public with the CCP amount to CFAF 118 million at end 2003. The main function of the CCP is the payment of the salaries of about 3,000 civil servants through the post office network. The civil servants typically withdraw the totality of their salary and do not keep the funds on deposit in their account. Thus the CCP, although providing a useful payment service, is not important as a financial intermediary.

\section{G. Summary and Conclusions}

45. The financial system of the C.A.R. is very underdeveloped. Most of the resources mobilized by the system are mobilized by the central bank in the form of currency in circulation. The counterpart of these resources is the accumulation of net foreign assets or claims on the government, as very little refinancing of the banks occur. The system thus does not yet play a large role in the efficient allocation of savings through the pooling of risks and the search for higher return by market-oriented financial intermediaries. The efficiency gains from financial deepening remain largely untapped.

46. In the short term, the single most important obstacle to a better functioning of the financial system is the inability of the state to meet its financial obligations, which undermines both the liquidity of the banking system and the solvency of some financial intermediaries. The first step of a strategy to develop the financial sector needs to be the resolution of the current fiscal imbalances. Other elements of such a strategy should be the reduction of the cost and risk of intermediation through improvement in the judicial system and other mechanisms for the enforcement of contracts, and a strengthening of the prudential 
regulation and supervision of the various components of the financial sector. One positive aspect of the current situation is that, because of the regional character of the institutional framework covering banks and microfinance institutions, the prudential supervision function has not been compromised by the debilitating effects of the recent military conflict or the public finance crisis that is undermining the effectiveness of the state. 


\section{Regional Integration: The Case of the Central African Republic ${ }^{22}$}

\section{A. Introduction}

47. The Central African Republic (C.A.R.) is a member of the Central African Economic and Monetary Community (CEMAC), a regional trade and monetary agreement that also comprises Cameroon, Chad, the Republic of Congo, Equatorial Guinea, and Gabon. The treaty establishing the CEMAC was signed on March 16, 1994, and the CEMAC was based on the institution of the Central African Economic Union (UEAC) and the Central African Monetary Union (UMAC). The CEMAC was meant to continue and reinforce the Central African Economic and Customs Union (UDEAC), established in 1964.

\section{The main statutory objective of the CEMAC is to strengthen and fully} implement the customs union among its member countries. In this vein, the treaty establishing the CEMAC introduced some major trade reforms aimed at reducing the level of external protection of the customs union and promoting members' national markets by creating a regional common market.

49. In addition to regional integration among member countries, the CEMAC aims to ensure the economic stability required to sustain the fixed exchange rate of the common currency. To this end, in 2001 the Council of Ministers of the CEMAC, following the example of the European Union, adopted a set of four macroeconomic convergence criteria member countries had to comply with. ${ }^{23}$

\section{This chapter analyses the regional integration efforts of the Central African} Republic in the context of the CEMAC, focusing on the regional trade integration dimension of the agreement. Thus, the first section of the paper presents an overview of the CEMAC customs union reform. The second section investigates the status of the implementation of the CEMAC trade reform in the Central African Republic. Finally, the last section evaluates the impact of the regional trade reform on the C.A.R.'s trade performance, based on trade developments in the C.A.R. during the period 1994-2002.

22 This section was prepared by Giorgia Albertin.

${ }^{23}$ The CEMAC's four regional macroeconomic convergence criteria are a nonnegative basic fiscal balance, in percent of GDP; consumer price inflation of no more than 3 percent; a level of total debt of no more than 70 percent of GDP; and the nonaccumulation of external or domestic payments arrears. 


\section{B. The CEMAC Customs Union Reform: An Overview}

\section{The institution of the CEMAC introduced major trade reforms to reduce the} level of extcrnal protection of the customs union and to establish a regional common market where goods and services, people, and capital may circulate without restrictions. Furthermore in order to support the implementation of the envisaged common market and promote its functioning, a complementary fiscal reform was introduced to harmonize member countries' domestic tax regimes.

52. The CEMAC reform, aimed at greater openness to trade, the creation of a single market, and the harmonization of domestic tax regimes, relied on several key factors. On the side of regional trade integration, the reform was based on the introduction of a common external tariff (CET), the implementation of a generalized preferential tariff (GPT), and the elimination of quantitative restrictions to trade. On the complementary fiscal side, the reform relied on the implementation of a common value-added tax (VAT). ${ }^{24}$

53. First, in order to fully implement the custom union, a CET was adopted at the CEMAC level and applied on imports from third countries. ${ }^{25}$ In order to enhance the transparency of the tariff, four different rates were introduced to be applied on four different categories of imported goods. Since then, the rates of the CET have been revised downward several times by the CEMAC authorities to promote greater openness to trade. Currently, the custom duty rates applied on imports from third countries are fixed at 5 percent for essential goods, 10 percent for raw materials and capital goods, 20 percent for intermediate goods, and 30 percent for consumer goods. The CEMAC authorities decided that the CET had to be applied on the c.i.f. values of imported goods, in order to reflect the transportation costs incurred in the import process. This practice was preferred to the use of f.o.b. values of imported goods, in order not to penalize the landlocked member countries of the customs union, notably the C.A.R. and Chad.

\section{Secondly, the GPT was introduced in order to gradually move toward the} creation of a single market. The introduction of the GPT was intended to reduce the level of protection of the members' domestic market against goods produced in CEMAC countries, in order to encourage intrazone trade. In fact, the GPT was envisaged to substitute for all other intrazone tariff barriers. The GPT was designated to be levied on imported goods originated in the CEMAC zone, and its rate was fixed at 20 percent of the CET that would have been applied to the category of the considered product. However, the GPT was conceived of as a temporary trade measure aiming to smooth the transition toward the removal of all tariff

${ }^{24}$ The initial 1994 reform introduced the tax-on-turnover, whose rate could be chosen by member countries in the range of 10 to 18 percent. The tax-on-turnover was replaced by the VAT by the subsequent reform in 1998.

${ }^{25}$ The CET substituted for the tax-on-turnover for imports and the complementary tax. 
barriers on intrazone trade exchanges. CEMAC member countries were expected to gradually reduce the rate of the GPT and to definitely eliminate it by January 1998.

55. As a further step, the reform established that all quantitative restrictions had to be dismantled ${ }^{26}$ In order to facilitate the adjustment of firms operating in industries that used to be protected through quantitative restrictions, an ad valorem temporary surcharge was introduced to complement the CET. The temporary surcharge could be levied on imports from any origin, including intra-CEMAC imports, but it could be applied only to those categories of goods that were previously subject to quantitative restrictions. Since the temporary surcharge was meant to protect the national domestic markets, each CEMAC country could autonomously choose its rate, up to a maximum of 30 percent. Similar to the implementation of the GPT, the temporary surcharge was intended to be a temporary trade measure, and member countries were expected to definitcly remove it by June 2000 .

\section{To support the implementation of the common market, the need for the} harmonization of members' domestic tax regimes was envisaged, and a common VAT was introduced. The VAT substituted for all indirect domestic taxes levied and was meant to be levied on economic activities involving production, import, or provision of services, while all export activities were exempted. Member countries were left with the choice of the turnover threshold, starting from which the VAT should have been applied, and with the choice of rate, within a range of $15-18$ percent. ${ }^{27}$ However, to avoid any form of discrimination between imports and local products, exemptions to the VAT were decided at the CEMAC level. ${ }^{28}$ In this vein, a list of VAT-exempted products and activities was defined, and member countries were expected not to provide any further exemptions beyond the CEMAC list.

57. Finally, in order to safeguard the budgetary needs of the CEMAC countries, the fiscal reform strengthened the use of the ad valorem excise tax. Thus, at the CEMAC level, a harmonized list of products eligible for the application of the excise tax was defined, and member countries were left with the choice of its rate, up to a maximum of 25 percent. $^{29}$

${ }^{26}$ Quantitative restrictions are a type of nontariff barriers to trade, and the most commonly used are import quotas and voluntary export restraints.

${ }^{27}$ See the CEMAC's Directive n. 1/99/CEMAC-028-CM-03, "Harmonisation des Législations des Etats-Membres en matière de Taxe sur la Valeur Ajoutée et du Droit d'Accise".

${ }^{28}$ The VAT rate is fixed at 0 percent for exempted product and activities, which include, among others, medicines and products of extractive activities.

${ }^{29}$ The reform established that all CEMAC member countries had to levy the excise tax on tobacco and alcohol, while its imposition on other eligible products was discretionary. 


\section{The Implementation of the CEMAC Reform in the C.A.R.: An assessment}

58. The C.A.R. has made important progress in the implementation of regional trade and fiscal reforms. While delays have arisen, as in most of the other CEMAC countries, in the implementation of the regional reform programs, currently the C.A.R.'s trade policies and practices, to a large extent, respect CEMAC regulations.
Central African Republic: implementation of the CEMAC reform

\begin{tabular}{llr}
\hline & Current Status & Rate \\
\hline Common External Tariff & Applied & $5 \%, 10 \%, 20 \%, 30 \%$ \\
Generalized Preferential Tariff & Eliminated & $0 \%$ \\
Tcmporary Surcharge & Eliminated & $0 \%$ \\
Common Value-Added-Tax & Applied & $18 \%$
\end{tabular}

Sources: CEMAC; Central African authorities.

\section{First, the C.A.R. is fully compliant with the implementation of the rate structure} of the CET, and no additional surcharges are imposed on imports from third countries (see table above). ${ }^{30}$ However, distortions are reported in the process of classification and attribution of the imported goods into the four customs duty categories. In fact, discriminatory practices are applied against imports from third countries by attributing imported goods to categories for which a higher duty rate applies. These practices are reported to arise with products that, because of the nature of their uses, could be classified in alternative customs duties categories. As an example, sugar imports are attributed to the category of consumption goods rather than raw materials and are, then, levied at a 30 percent custom duty rate, the highest rate established by CEMAC regulations.

\section{In conformity with CEMAC regulations, in the C.A.R. customs duties are levied} on the c.i.f. value of the imported products. However customs fraud is still a major problem in the C.A.R., and protracted negotiations with customs officcrs are reported to be common. In order to reduce the incidence of customs fraud, the CAR's government has recently invested a private agency, named the "Bureau Veritas" (BIVAC), with a mandate to verify the declared value of imports and to evaluate its conformity with the prices usually applied on the international markets. ${ }^{31}$ The threshold for inspectable imported products is currently fixed at CFAF 1 million (about US\$1,700).

${ }^{30}$ Since January 2002, the additional community integration tax (TCI) is levied on imports from non-CEMAC countries, and its rate is fixed at 1 percent. The TCI is part of the CEMAC's financing mechanism, and 30 percent of the collected revenue is allocated to the functioning of the CEMAC, while 70 percent is allocated to the Community Development Fund.

${ }^{31}$ The contract between the C.A.R.'s authorities and the BIVAC was signed in November 2003. 
61. In addition, the C.A.R. has effectively implemented the elimination of quantitative restrictions and the related compensatory temporary surcharge. In conformity with the CEMAC's requirements, the C.A.R. has dismantled most of its nontariff barriers to trade. However, a significant quantitative restriction is still enforced in the form of prior authorization required for sugar imports. The C.A.R. has definitely eliminated the ad valorem temporary surcharge it had introduced to protect local products during the process of elimination of quantitative restrictions. In the C.A.R., the temporary surcharge used to be levied on imports of any origin, and its rate was 30 percent, the highest admitted by CEMAC regulations.

\section{Furthermore, the C.A.R. is compliant with the implementation of the single-} market regulations, such that imports from CEMAC member countries are duty free. In fact, over the ycars, the C.A.R. has gradually reduced the GPT that was imposed on intraCEMAC imports, and recently the GPT was eliminated, as established by CEMAC requirements. Thus, currently, the C.A.R. does not impose any tariff barrier on imports of goods that, on the basis of CEMAC's "rules of origin," are provided with a CEMAC certificate.

63. The CEMAC's rules of origin are the overall body of regulations that are used to determine the origin of a good, and whether it was made in the CEMAC zone. Given the preferential nature of the CEMAC trade agreement, rules of origin play a crucial role, since levied customs dutics vary according to the origin of the imported product. CEMAC's rules of origin mainly distinguish between primary and manufacturing products. On the one hand, a primary product is considered to have a CEMAC origin if it has been produced in any of the CEMAC member countries. On the other hand, rules of origin for manufacturing products rely on ad valorem criteria, based on the raw material used in the production of the good or, alternatively, on the value-added incorporated in the product. Thus, a manufacturing product is provided with a CEMAC certificate if at least 50 percent of the incorporated raw material is of CEMAC origin or, alternatively, if at least 40 percent of the value added of the good has originated in other CEMAC member countries. ${ }^{32}$

64. The C.A.R. suffers from substantial tariff revenue losses implied by the extensive fraud in the attribution of certificates of CEMAC origin. It is reported that imported goods enter the C.A.R.'s territory with certificates that attest to their CEMAC origin and, as a consequence, free of duty, while they are not compliant with the CEMAC rules of origin, and should be subjected to the existing customs duties. This fraudulent practice in the attribution of certificates of CEMAC origin is reported to be frequent on goods imported from Cameroon.

\footnotetext{
32 The customs union reform in 1994 introduced the ad valorem criterion based on the content of raw material. However, due to the difficulties encountered by CEMAC's firms in complying with this requirement, the complementary criterion based on the value added was introduced.
} 
65. The fraud in the attribution of the CEMAC certificates of origin lies in the generalized corruption of customs union officials, as well as in an inherent weaknesses at the CEMAC institutional level. While, on the one hand, CEMAC rules of origin have been defined at the regional level, on the other hand, a centralized institution charged with the attribution of certificates of CEMAC origin has not been created. Thus, the attribution of certificates of CEMAC origin is left to the discretion of customs union officials of the place of production, a practice that leads to the poor implementation of the CEMAC's rule of origin and to widespread diffusion of fraudulent behavior.

66. Finally, relative to the fiscal aspects of the regional reform, the C.A.R. is compliant with the implementation of the CEMAC's VAT and its rate structure. In the C.A.R., the VAT is levied on economic activities involving production, imports, and provision of services by legal entities (companies and partncrships), while all cxport activities are exempted. In the C.A.R., the turnover threshold for the VAT application has been fixed at CFAF 30 million, the applied rate is currently 18 percent, and no use of ad hoc exemption is reported. As required by the CEMAC's directives, the introduction of the VAT substituted for other indirect taxes previously implemented in the country. ${ }^{33}$ However, as allowed by CEMAC regulation, the C.A.R. levies an ad valorem excise tax with a 23 percent rate on a set of products included in the CEMAC's list. ${ }^{34}$

\section{The Effects of the Trade Reform on C.A.R.'s Trade Performance}

67. Due to the important progress in the implementation of the CEMAC regulation, the current C.A.R.'s trade regime is quite open. The C.A.R. is currently rated 3 (on a standard 1-10 scale with 10 being the most restrictive) on the Fund's trade restrictiveness index, based on a moderate tariff level (18 percent unweighted average) and a few non-tariff barriers. $^{35}$

68. Since 1994, the progressive implementation of the CEMAC trade reform has affected the C.A.R. trade regime in two main respects. On the one hand, the C.A.R. level of external protection has been significantly reduced, following the adoption of the common external tariff and the elimination of most quantitative restrictions. On the other hand, tariff

${ }^{33}$ In the C.A.R., the introduction of the VAT substituted for the implementation of unique local taxes, domestic taxes on consumption, domestic taxes on production, the domestic consumption tax, the transaction tax, the tax-on-turnover from imports, and the tax on domestic turnover.

34 The C.A.R. levies the excise tax on alcohol, tobacco, cement, tea, salt, eggs, cosmetics, luxury goods, passenger vehicles, arms, and explosives.

${ }^{35}$ All other CEMAC countries are currently rated 4 on the Fund's trade restrictiveness index, with the exception of Cameroon and the Republic of Congo, which are rated 3. 
and nontariff barriers on trade with other CEMAC member countries have been eliminated through the participation in the CEMAC common market.

\section{The reduction in external trade protection has had a limited positive impact on} the C.A.R.'s trade with non-CEMAC countries. The C.A.R. trade with non-CEMAC countries is the main component of C.A.R. overall trade, and it represented, on average, about 93 percent of total trade during 1994-2002. After an initial peak in trade in 1994, in spite of the progressive reduction in the level of external protection, exports and imports as a share of GDP have continuously decreased (see figure III.1). ${ }^{36}$ In particular, the C.A.R. economy has become increasingly isolated in recent years, with non-CEMAC exports and imports reaching, respectively, only 14 percent and 10 percent of GDP in 2002.

70. Similarly, so far the impact of participation in the common market on C.A.R. trade with CEMAC countries has been limited. During 1994-2002, CAR's trade with CEMAC countries represented, on average, only 7 percent of its overall trade (see figures III.3 and III.4). Starting from 1994, both C.A.R. exports and imports to CEMAC as a share of GDP slightly increased, reflecting some positive trade effects of the reduction in intrazone tariff barriers (see figure III.2) ${ }^{37}$ However, this moderate positive trend was limited in time. Starting from 1998, C.A.R.'s imports and exports to CEMAC, as a share of GDP, gradually declined, and they reached, respectively, only 1 and 0.1 percent of GDP in 2002.

71. Furthermore, the C.A.R. appears to be narrowly integrated at the regional level, as shown by its limited contribution to intra-CEMAC trade. The contribution of C.A.R. to intra-CEMAC overall trade, after an initial rebound, gradually decreased from 14 percent in 1994 to less than 5 percent in 2002 (Figure III.7). In fact, C.A.R. exports and imports with CEMAC countries as a share, respectively, of total intra-CEMAC exports and imports, after a slight initial increase, started to significantly decrease (Figures III.5 and III.6). The share of C.A.R. imports to CEMAC in total intra-CEMAC imports decreased from 25 percent in 1994 to 9 percent in 2002, while the share of C.A.R. exports to CEMAC in total intra-CEMAC exports decreased from 3 percent in 1994 to 0.5 percent in 2002.

72. The narrow impact of the CEMAC trade reform on C.A.R.'s trade performance may be explained by the existence of structural barriers to trade in the C.A.R. economy. In fact, the progressive deterioration in the economic and security situation, the inherent political instability, the poor transport infrastructure, and the high incidence of transportation costs, represented significant structural constraints on C.A.R. trade during the period 19942002. Thus, in spite of C.A.R.'s efforts to comply with the CEMAC trade reform and its

${ }^{36}$ In 1994, C.A.R.'s exports and imports to non-CEMAC countries increased, respectively, to 20 percent and 16 percent of GDP, reflecting the positive impact of the devaluation of the CFA franc and the reduction in external trade protection.

${ }^{37}$ In 1997, C.A.R. exports and imports to CEMAC countries, as a share of GDP, increased, respectively, to 2.4 percent and 0.7 percent of GDP. 
consequent greater openness to trade at the regional and international level, structural constraints on the development of C. $\Lambda . R$. trade have, so far, hindered the emergence of the potential trade-enhancing effects of the reform.

Figure III.1 Central African Republic: Exports and Imports with

Non-CEMAC Countries, 1993-2002

(In percent of GDP)

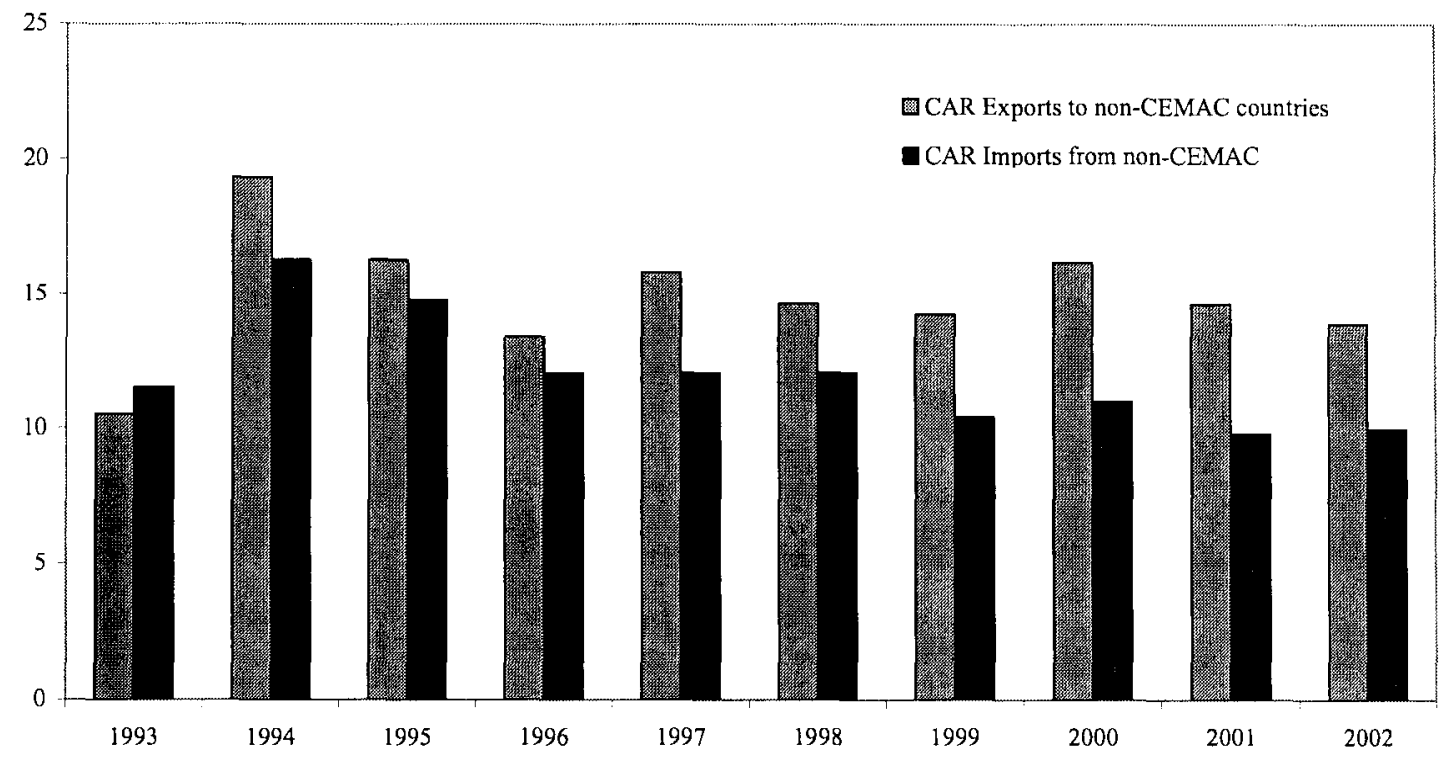

Sources: IMF, Direction of Trade Statistics; and staff estimates. 
Figure III.2 Central African Republic: Exports and Imports with CEMAC Countries, 1993-2002 (In percent of GDP)

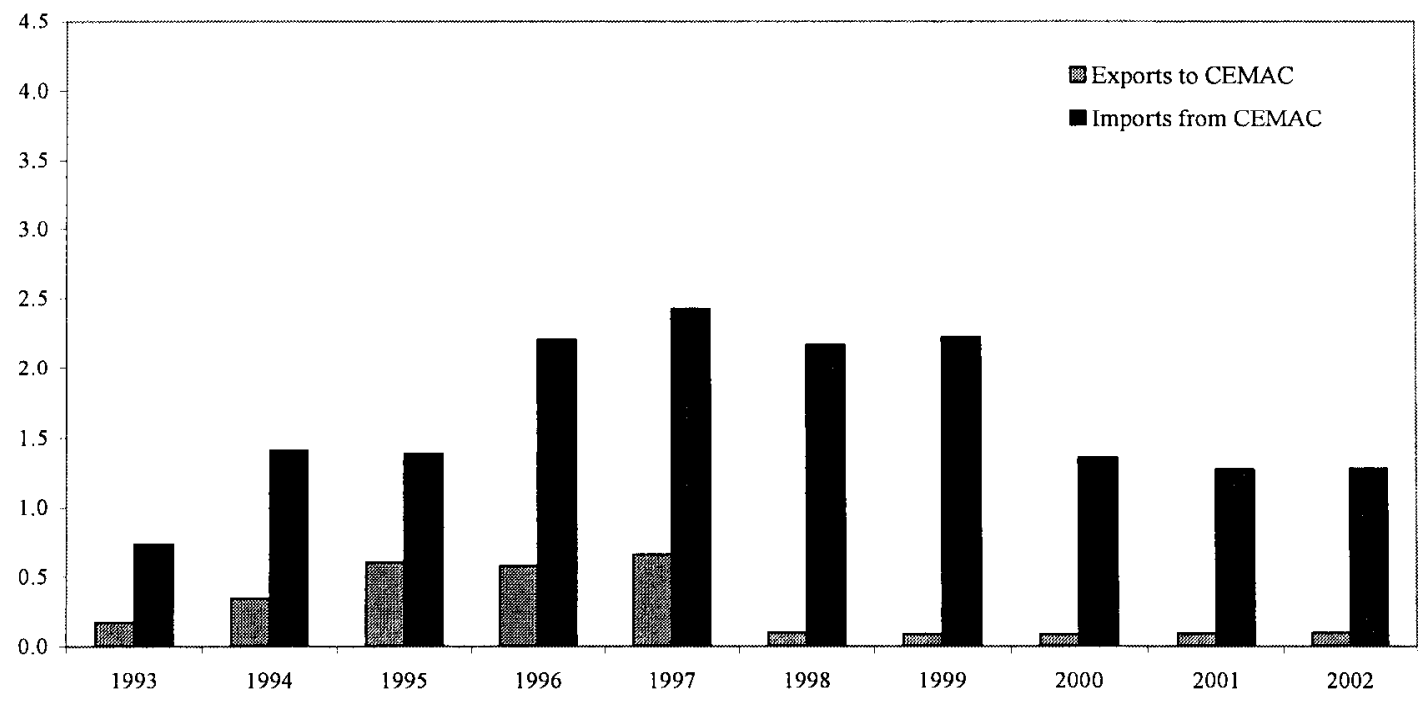

Sources: IMF, Direction of Trade Statistics; and staff estimates.

Figure III.3 Central African Republic: Exports to CEMAC Countries, 1993-2002 (In percent of total exports)

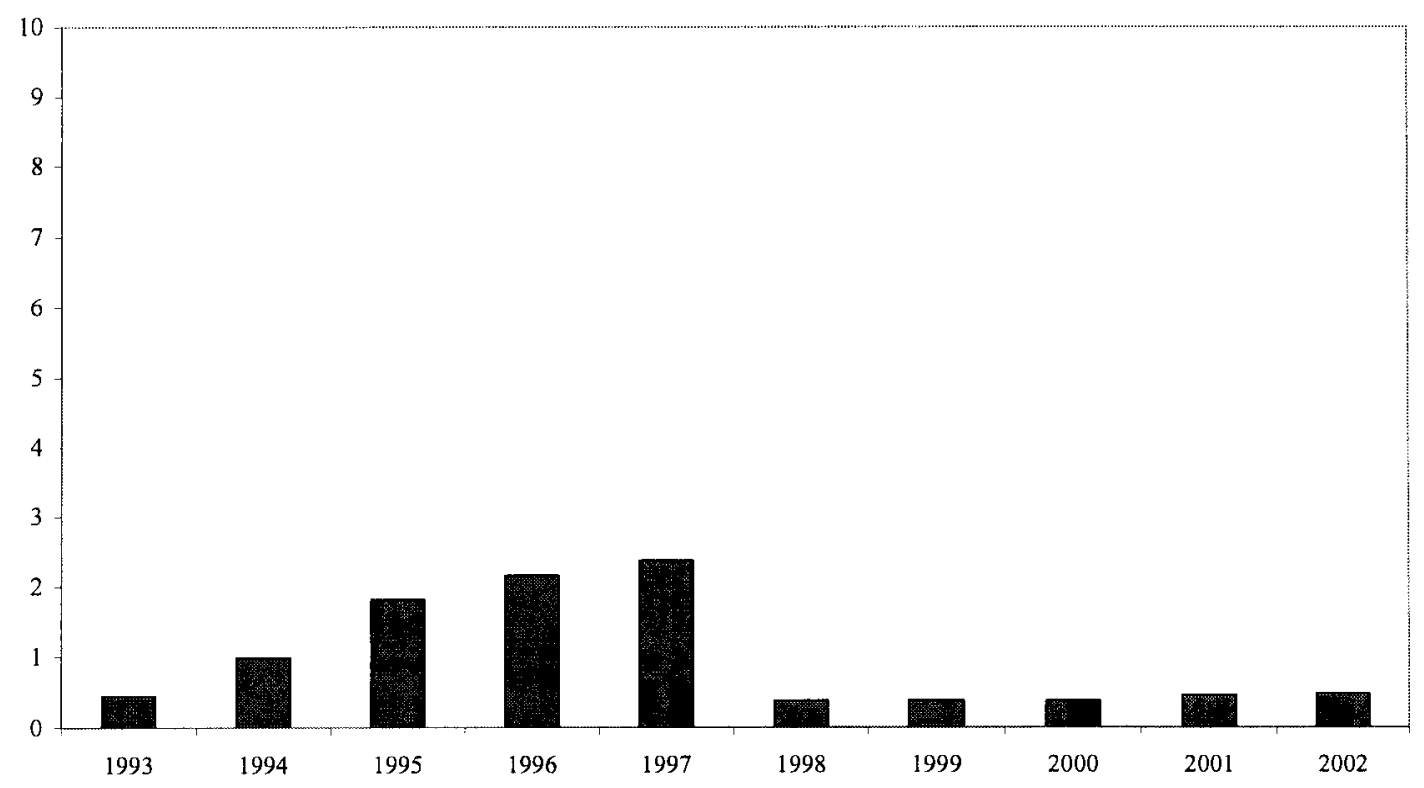

Sunrces: IMF, Direction of Trude Statistics, and staff estimates. 
Figure IIl.4 Central African Republic: Imports from CEMAC Countries, 1993-2002 (In percent of total imports)

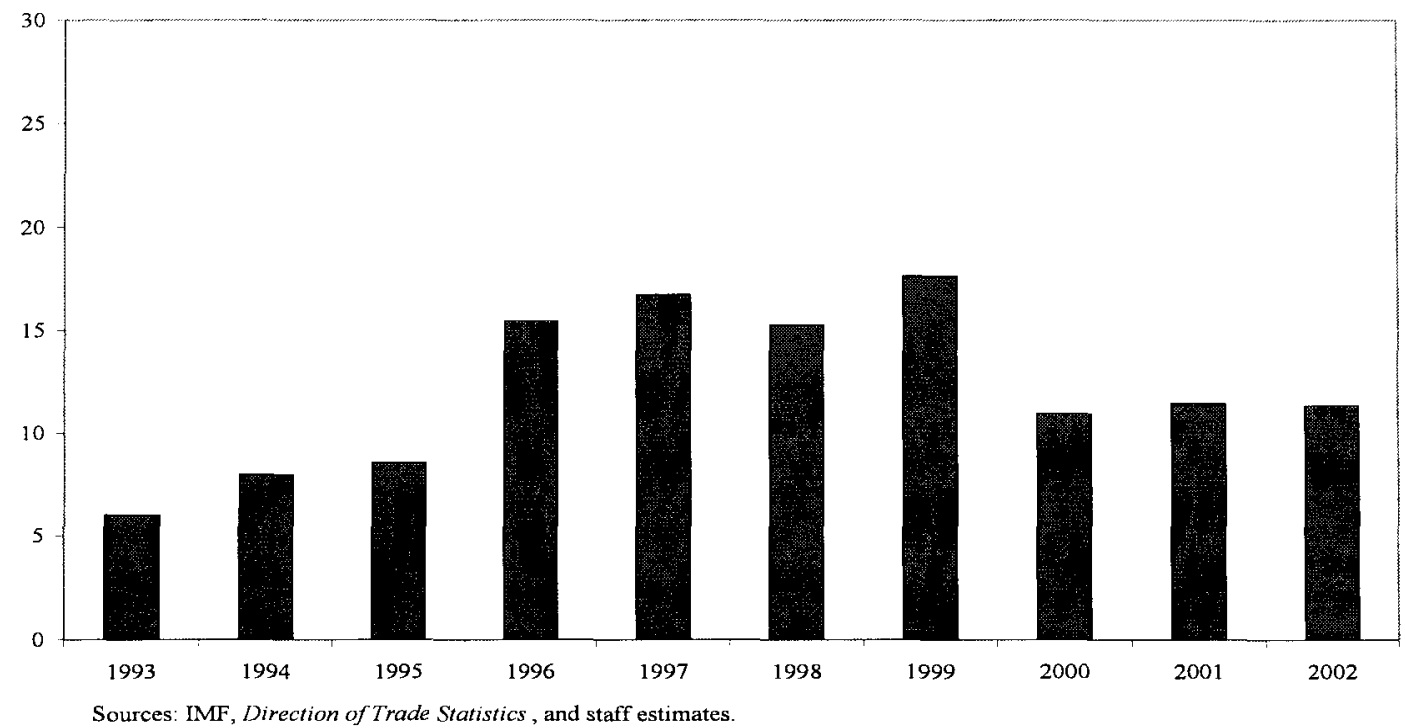

Figure III.5 Central African Republic: Exports to CEMAC Countries, 1993-2002 (In percent of total intra-CEMAC exports)

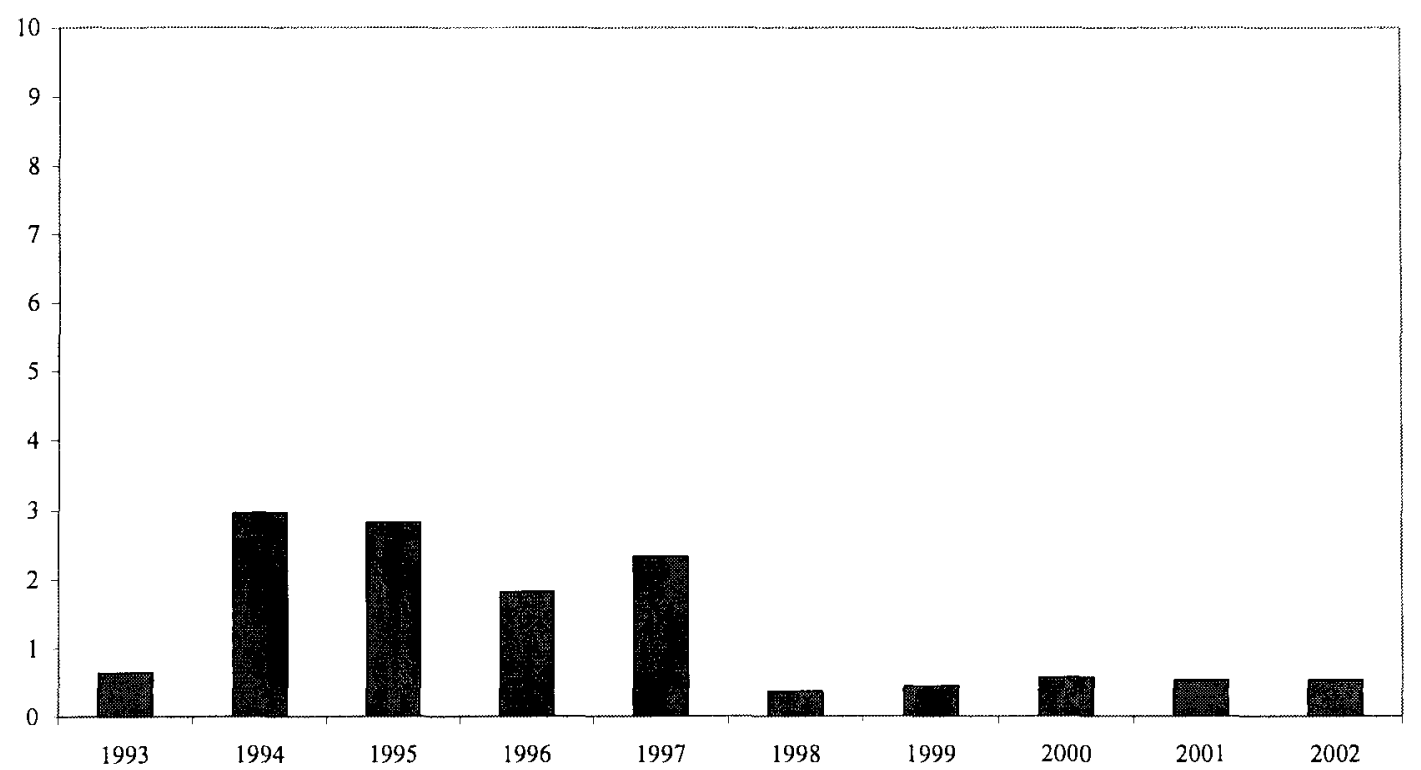

Souces: IMF, Direction of Trade Statistics; and staff estimates. 
Figure III.6 Central African Republic: Imports from CEMAC Countries, 1993-2002 (In percent of total intra-CEMAC imports)

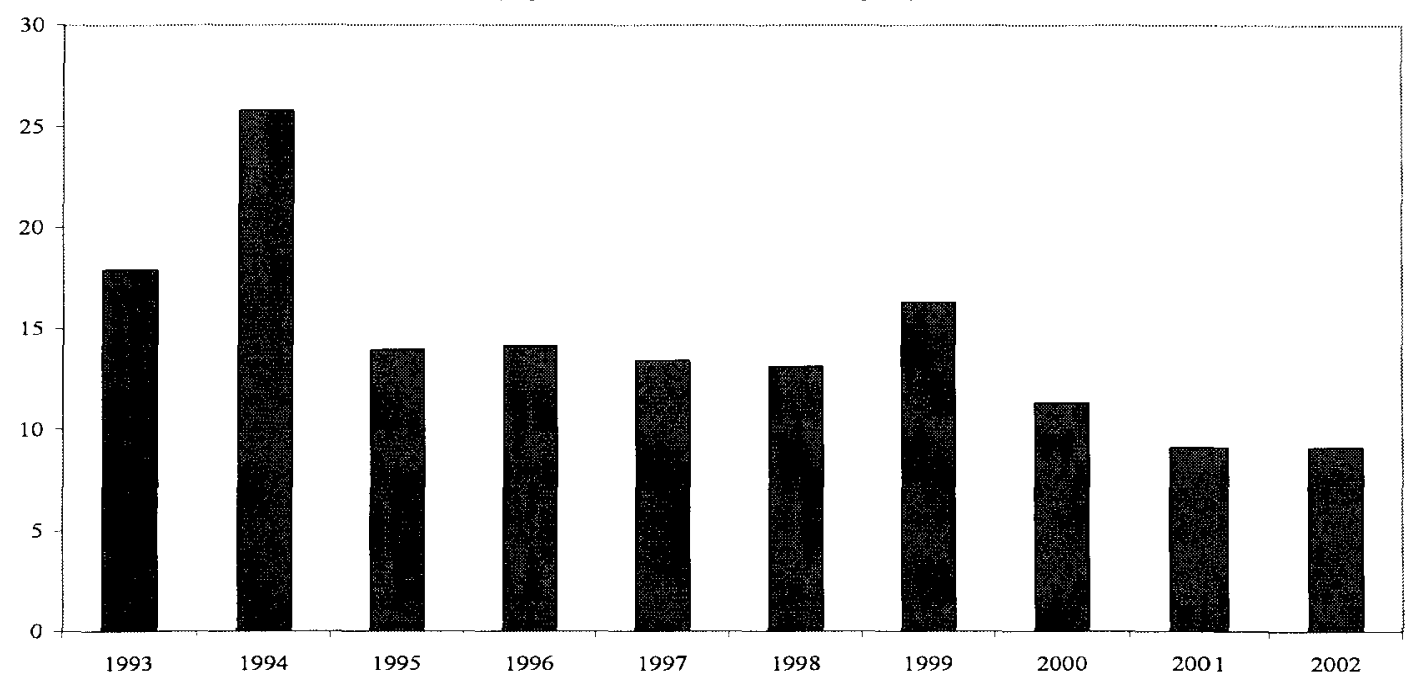

Sources: IMF, Direction of Trade Statistics ; and staff estimates.

Figure III.7 Central African Republic: Trade with CEMAC Countries, 1993-2002 (In percent of total intra-CEMAC trade)

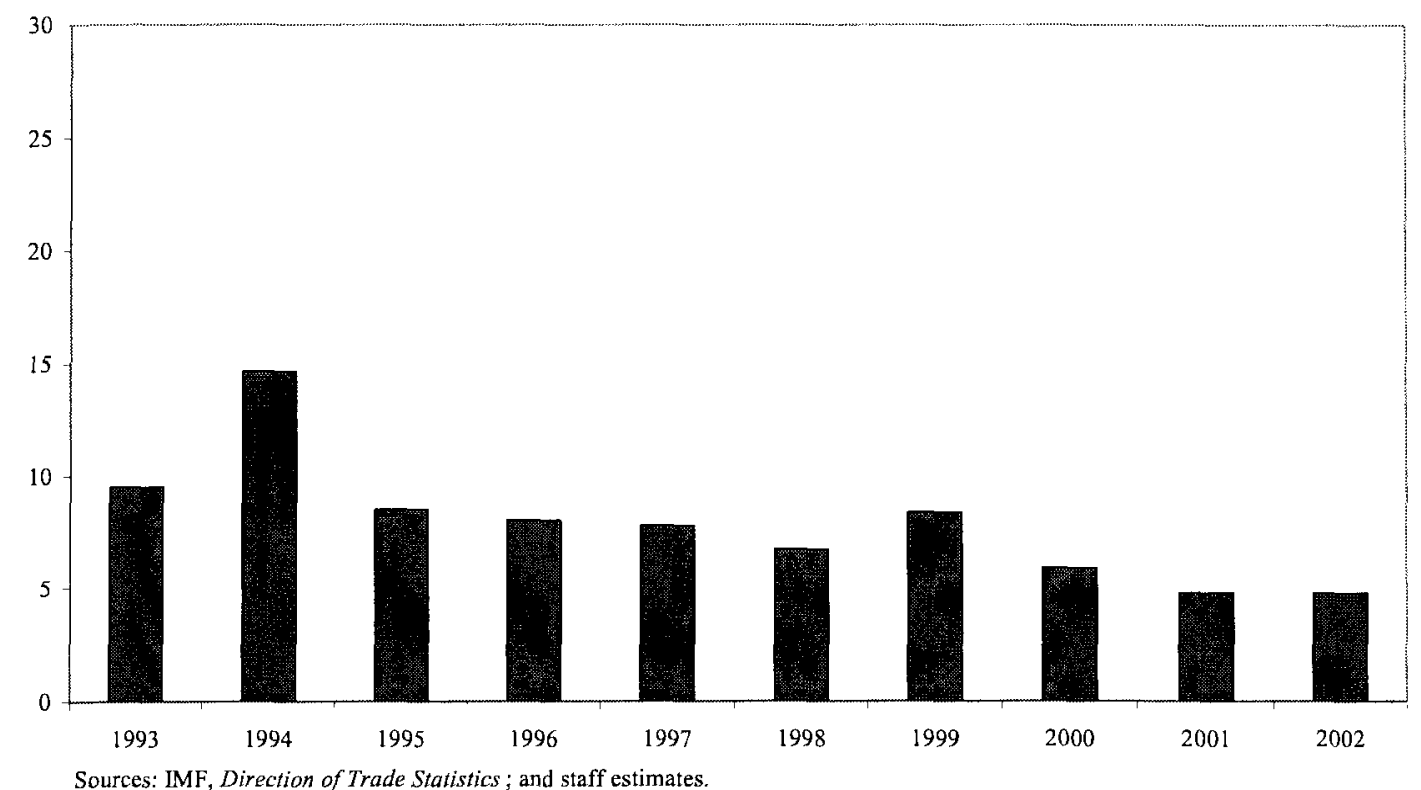

Sources: IMF, Direction of Trade Statistics; and staff estimates. 


\section{IsSues Related to the Diamond SECTOR ${ }^{38}$}

\section{A. Introduction}

73. The Central African Republic is the seventh-largest producer in Africa and the tenth-largest producer in the world for rough (uncut) diamonds. ${ }^{39}$ With an official annual production of some 450,000 carats per year, diamonds account for about 40 percent of the country's export proceeds and about 7 percent of its GDP. Moreover, the country ranks fifth in the world with respect to the overall quality of its diamonds: $70-80$ percent are of gem quality and are used in jewelry. ${ }^{40}$

74. In spite of the sector's potential, neither diamond miners nor the C.A.R. government is able to reap much revenue from diamonds. Diamond miners are among the poorest segments of society, and the government obtains less than 5 percent of its fiscal revenue from the sector. This section attempts to explain this low level of revenue, and finds that it is due partly to the alluvial nature of C.A.R. diamond deposits, and partly to the organization of the sector, both of which facilitate smuggling. As a result, the true value of C.A.R. diamond exports may be at least twice as high as official figures suggest. The history of the C.A.R. diamond sector and its market structure are described in Subsections B and C, respectively. Subsection D discusses the tax regime and tax evasion. Finally, Subsection E discusses possible diamond sector reforms that could help to (i) strengthen the position of diamond mincrs, (ii) reducc tax evasion, and (iii) stimulate foreign and domestic investment in the sector.

\section{B. History}

75. Diamond deposits generally occur in one of two types of formations. The most lucrative are so-called kimberlite deposits, which are concentrated in volcanically derived, cone-shaped pipes. In countries where such deposits occur (e.g., Botswana, South Africa, Namibia, Russia, Australia, and Canada), diamond production is typically in the hands of large-scale corporations that use highly mechanized mining technology on sites that are well fenced and have tight security.

76. Diamond deposits in the Central African Republic are of a secondary, "alluvial" type. Alluvial deposits consist of diamonds that have been released from eroded kimberlite

\footnotetext{
${ }^{38}$ This section was prepared by Nienke Oomes in early 2003. Although the analysis in the paper remains valid, some of the institutional arrangements in the sector may have changed in the intervening period.

${ }^{39}$ Ministry of Mines, Energy, and Water Resources (2002); Harris (2001); and Rombouts (2000).

${ }^{40}$ Ministry of Mines, Energy, and Water Resources (2002).
} 
pipes and may have been transported by river systems over long distances. They are found on the floors and banks of ancient and contemporary rivers, and are spread out over extended areas. Despite the large volume of alluvial diamond deposits in the Central African Republic, the source of these deposits has not yet been discovered. One possibility is that they originate from kimberlite pipes in the northern and eastern regions of the Democratic Republic of the Congo (DRC). However, according to the Canadian company Vaaldiam, the geology of a significant portion of the Central African Republic itself favors the discovery of kimberlite pipes that could be the primary hosts from which its diamonds were originally eroded.

77. Since alluvial diamond mining areas cannot be fenced off and are often located in remote parts of the country, it is difficult to establish appropriate security arrangements for commercial exploitation. After the discovery of diamonds in the Central African Republic in 1914, diamond exploitation between 1931 and 1961 was controlled by French and other foreign mining companies. Following the country's independence in 1960 and the adoption of new mining legislation in 1961, exploitation has been gradually taken over by individual artisanal (small-scale) miners, collectors, and purchasing bureaus. ${ }^{41}$

\section{The shift to artisanal exploitation led to a boost in average annual diamond} production, from 75,000 carats between 1931 and 1961 to 506,000 carats between 1963 and 1972 (Figure IV.1). After a record 635,935 carats in 1968, however, production dropped significantly during the 1970s under the Bokassa regime and reached a low of 277,000 carats in 1982. According to the Ministry of Mines, Energy, and Water Resources (2002), the main reasons for this drop in production were the negligence of the authorities, tax and customs constraints, the closing of some mining companies owing to a lack of security for their investors, and poor organization of the artisanal miners.

79. In the course of the decade 1983-92, production increased significantly, reaching a yearly average of 493,000 carats. This improvement was due to a renewal of control over the sector by the authorities, who, in the face of constraints, took a number of measures aimed at promoting the mining sector, including the creation in 1988 of BECDOR (Bureau d'Evaluation et de Contrôle de Diamants et d'Or), a governmental agency charged with overseeing diamond production prior to export.

\footnotetext{
${ }^{41}$ While some artisanal production took place during the period 1931-61, no accounting records of this type of production during the period exist (Ministry of Mines, Energy, and Water Resources, 2002.)
} 
Figure IV.1. Central African Republic: Average Volume of Diamond Exports, 1931-2002 (In thousands of carats)

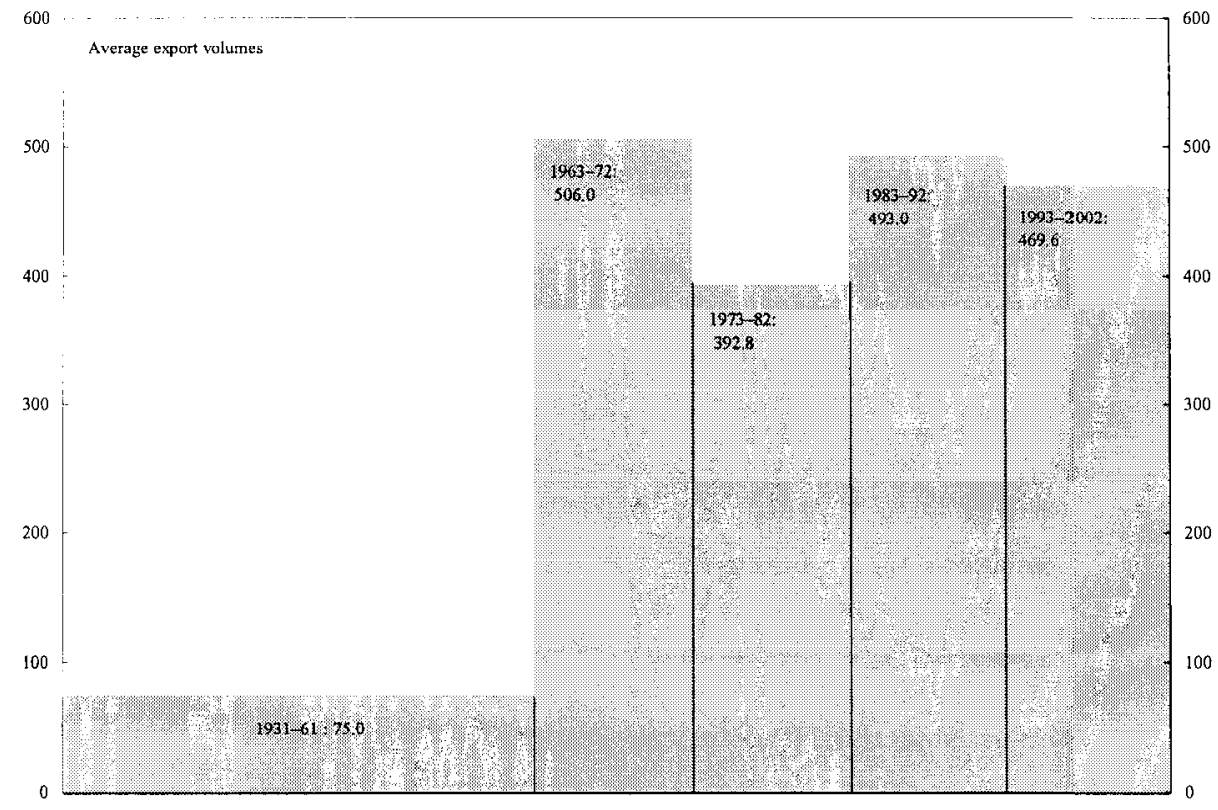

Source: C.A.R. authorities.

Figure IV.2. Central African Republic: Volume of Diamond Exports, 1987-2002 (In thousands of carats)

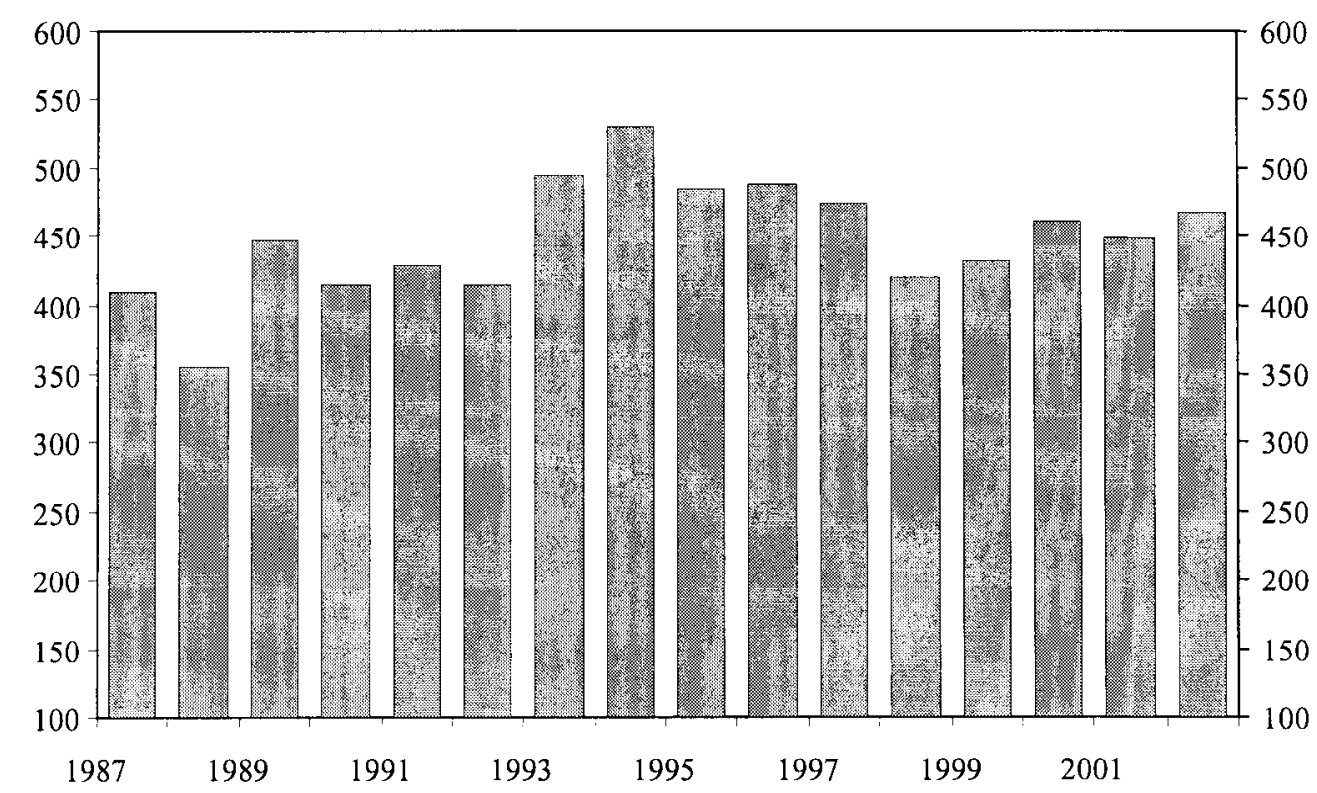

Source: C. A. R. authorities. 
80. Since 1994, the government's measures have been enhanced by the creation of regional administrations designed to bring the producers closer to the government agencies and to support miners' cooperatives; by the creation of a diamond exchange; by a reduction in the rate of export duties on diamonds (from $71 / 2$ percent to 6 percent in 1998); and by the establishment of a reward for reporting smuggling. These measures resulted in a temporary increase in production to 531,000 carats in 1994, an increase of about 8 percent compared to 1993. However, since then, production has fallen somewhat and has averaged around 450,000 carats per year (Figure IV.2).

\section{Market Structure}

81. At present, the exploitation of C.A.R. alluvial diamond deposits is almost exclusively artisanal in nature. ${ }^{42}$ The exploitation involves about 100,000 manual workers, 60,000-80,000 artisanal miners ("artisans"), 200-400 collectors, and 8-10 diamondpurchasing bureaus. $^{43}$

82. Manual workers are typically young, male, and poorly educated, with few employment alternatives (Goreux, 2001; and Economist, 2000). They tend to work in poor and remote rural areas of the country and to lead a nomadic lifestyle, traveling from one area to another. They use rudimentary equipment, such as picks, shovels, primitive pumps, and sieves, and sometimes even work manually, digging and searching an area by hand. In addition to their low earnings, they endure work conditions in mining regions that are unsafe, unstable, and unhealthy. ${ }^{44}$

83. Artisanal miners ("artisans") are not much better off. An artisan is essentially a more entrepreneurial and less risk-averse manual worker who hires a group of manual workers, feeds them, pays them a wage, and buys them their mining permits (carte d'ouvrier minier), which they need to access the mining zones, and which also serve to indicate which worker is employed by which artisan. ${ }^{45}$ While artisans may receive some 50 percent of their

${ }^{42}$ Nonartisanal exploitation currently constitutes only a very small part of total diamond production: less than 10 percent, according to Dietrich (2000), and less than 2 percent, according to the C.A.R. Ministry of Mines, Energy, and Water Resources (2002).

Nonartisanal exploitation is done by several small local mining companies, some of which have joint ventures with foreign companies or individuals, and by several companies with temporary mining permits (Dietrich, 2002, pp. 18 and 20.)

${ }^{43}$ The exact numbers are uncertain, since many agents remain unofficial. According to Jones (2002b, 2002c), there were three diamond-purchasing bureaus in Bangui in 1996, six in 1999 , and ten in 2002.

44 Anecdotal evidence suggests that adult HIV/AIDS prevalence rates in mining regions are higher than the national average of about 14 percent (see Goreux (2001); and Jones (2002a)).

${ }^{45}$ In certain cases, the artisan may also purchase an exploitation permit for the group, which 
group's output in exchange, this arrangement does not necessarily make them rich, as they have to pay their workers even when no diamonds are found.

84. Artisans tend to be poor because of three factors. First of all, as alluvial diamonds are spread out over a wide area, the work is highly labor intensive, and an unlucky artisan can go for weeks or months without finding any diamonds. Nevertheless, the prospect of striking it rich one day encourages artisans to continue searching for diamonds in regions that may, in fact, be uneconomical to exploit. Second, artisans typically live and work in remote areas, which makes it difficult to obtain a competitive price for their diamonds. Third, most artisans have a lack of capital and no access to credit, which makes it difficult for them to invest in equipment and to survive during times when no diamonds are found.

\section{The financing problem of artisans is effectively solved by so-called collectors,} who buy diamonds from artisans in order to sell them elsewhere for a higher price. There are about 200 officially registered collectors in the Central African Rcpublic, the majority of whom are foreign nationals (e.g., Senegalese, Mauritanians, Malians, and Lebanese). ${ }^{46}$ Collectors bear artisans' risks by providing them with advance payments in exchange for the exclusive right to buy their diamonds. The advance payment is typically in kind and consists of mining permits, equipment, food, clothing, and medicine, thus enabling artisans and their workers to sustain themselves during the periods in which they do not find any diamonds. In return, artisans are subject to implicit contracts that require them to sell their diamonds to a particular collector. ${ }^{47}$

\section{Implicit contracting between collectors and artisans implies that collectors have} a high degree of market power and are generally much better off than artisans. ${ }^{48}$ Because they effectively constitute a monopsony, collectors can pay artisans a price well below their diamonds' market value. (This price can be even lower because artisans may not know the value of the diamonds and the cost of the in-kind advance.)

\section{Becoming a collector requires a significant amount of start-up capital. For} collectors to be successful, they need to be able to spread their risk by financing multiple

gives the right to search for diamonds in a given mining area.

${ }^{46}$ Foreign collectors need to satisfy the following conditions: (i) they must have lived in the Central African Republic for at least five years without interruption; and (ii) they must provide proof that they have invested at least CFAF 20 million in fixed capital.

47 Anecdotal evidence suggests that noncompliance with this contract is punished with physical force or even murder.

48 Jones (2002a) reports that, while artisans are one of the poorest groups in society, collectors can typically afford luxuries like running water, electricity, electronics, and sometimes even motorbikes and cars. 
artisans at the same time (sometimes by means of another level of middlemen, called coxeurs). In addition, they are required to pay a license fee of approximately CFAF 1 million, or US\$1,400 per year. Like artisans, collectors are therefore subject to capital constraints.

\section{The purchasing bureaus of diamond export companies are to collectors what} collectors are to artisans. They bear collectors' risk by paying their license fecs and by providing them with advance payments both in kind and in cash, in return for the exclusive right to buy their diamonds. Export companies can spread their risk by financing multiple collectors, which requires a large amount of start-up capital. Moreover, current C.A.R. legislation requires that export companies pay significant installation costs to set up a diamond purchasing bureau. ${ }^{49}$

\section{Together, the capital requirements and installation costs for export companies} constitute important barriers to entry, as witnessed by the fact that there are currently only eight purchasing bureaus registered in the Central African Republic. These barricrs to entry, and the implicit contracts between export companies and collectors, imply that collectors are paid a price for their diamonds that is well below the international market price. ${ }^{50}$ As will be discussed below, this situation increases their incentives to smuggle.

\section{Taxation}

\section{Tax regime}

90. The appropriate tax regime for a diamond-exporting country depends on the nature of its diamond deposits. Countries with kimberlite deposits typically have tax regimes that rely on corporate income taxes and dividends, and government revenue from the diamond sector is generally substantial in these countries. In countries with alluvial deposits, however, the earnings of artisans and collectors are difficult to verify, as mining areas are large and costly to control. Like in other countries with alluvial diamond deposits (e.g., Angola, the DRC, Sierra Leone, and Liberia), the C.A.R. tax regime is built, therefore, around license fees and export duties, the revenue from which is generally low. ${ }^{51}$

${ }^{49}$ Export companies are required to (i) pay a license fee of CFAF 5 million; (ii) deposit CFAF 100 million in a trust fund (fonds de garantie) for five years; (iii) deposit another CFAF 100 million in a reserve fund to guarantee their solvency.

${ }^{50}$ Collectors with more initial capital depend less on purchasing bureaus and can receive a higher price for their diamonds.

${ }^{51}$ Even large corporations operating a mine have profit-to-revenue ratios of less than 50 percent in alluvial mining regions and, therefore, inevitably generate lower tax revenues from the sector. 
91. Export duties constitute the main source of government revenue from diamonds in the Central African Republic. These are collected by the state-run valuation office, BECDOR, and the current tax rate is 6 percent. $^{52}$ In 2001, fiscal revenue from diamonds amounted to approximately CFAF 2.5 billion (about US $\$ 3.4$ million), or 3.7 percent of total fiscal revenue. As discussed in the next subsection, part of the reason for this low revenue is tax evasion.

92. Revenue collected from license fees is relatively low. The cost of the mining permits required of manual workers and artisans is almost negligible (CFAF 1,000 for a carte d'ouvrier minier, that is, a little over US\$1). The more significant license fees are those imposed on collectors and on purchasing bureaus, which amount to CFAF 1 million and CFAF 5 million per year, respectively. With some 200 registered collectors and 8 purchasing bureaus, this gives a total annual revenue of CFAF 240 million, which is less than 10 percent of the tax revenues from diamond exports in 2001 .

\section{Tax evasion}

93. It is widely believed, including by the C.A.R. authorities, that the true value of C.A.R. diamond exports may be at least twice as high as official figures suggest. ${ }^{53}$ If correct, this implies an effective tax evasion rate of at least 50 percent. Taxes can be evaded by either (i) smuggling diamonds abroad; or (ii) underreporting their export value.

94. Smuggling diamonds is attractive, and most likely inevitable, because the payoff is large while the risk is low. ${ }^{54}$ The payoff is large because (i) diamonds have one of the highest values per unit of weight; (ii) black market prices are significantly higher than the prices paid by export companies (for reasons discussed above); and (iii) tax rates on diamond exports are lower in some neighboring countries (e.g., Chad, the Republic of Congo, the DRC, and Angola). The risk is low because (i) diamonds are small, and thus easy to conceal; (ii) diamond-mining areas are difficult to control; and (iii) it is difficult for experts to determine the origin of diamonds, especially when diamonds from different areas are mixed (Goreux, 2001, p. 9).

95. The undervaluing of diamonds is facilitated by the fact that official BECDOR valuators are paid relatively low salaries, compared with the size of the surplus to be shared. They are thus prone to, and are regularly suspected of, accepting offers to underreport

${ }^{52}$ Of which 5 percent for export duties, 0.25 percent for computing licenses, and 0.75 percent for the Mining Sector Development Project (Projet de Développement du Secteur Minier, or PDSM.)

${ }^{53}$ Statements of this kind are made by the Ministry of Mines, Energy, and Water Resources (2002), Harris (2001), and Mwamba (2002).

${ }^{54}$ Economist (2002). 
the export value of diamonds in exchange for part of the export tax savings. ${ }^{55}$ However, C.A.R. diamonds are also valued in Antwerp, the point of import for virtually all C.A.R. diamonds. Antwerp valuators have no interest in undervaluing imports, since diamonds from the Central African Republic, a country associated with the European Union (EU) under the Lomé Convention, are exempted from import tax. It is to be expected, therefore, that Antwerp data on C.A.R. diamonds provide a better estimate of their value.

96. Table IV.1 compares C.A.R. data on diamond exports, as reported by the country's official valuation office (BECDOR), with data on C.A.R. diamond imports reported by the Diamond High Council (Hoge Raad voor de Diamant, HRD) in Antwerp. The difference between the export prices reported by these two sources gives an estimate of the extent to which undervaluation takes place. At the same time, the difference in reported export volumes gives an indication of the amount of smuggled diamonds.

\section{The C.A.R. (export-based) data between 1995 and 2001 show consistently} smaller export volumes than the Antwerp (import-based) data, with the difference increasing significantly after 1998. In the period 1995-97, import-based data on export volumes were on average 23 percent higher, corresponding to an average difference of some 111,000 carats. Starting in 1998, the two data sets show an even bigger difference in volumes, amounting to almost 200 percent of the C.A.R. data in both 1999 and 2000. This difference can be explained in several ways.

\section{The first explanation is that the difference in volumes corresponds to C.A.R} diamonds that were smuggled out of the country but still declared in Antwerp as C.A.R. diamonds. If this were the only explanation of the difference, this would mean that as much as two-thirds of all diamonds produced in the Central African Republic in 1999 and 2000 were smuggled, which seems implausible. Moreover, this number would be even higher if some smuggled C.A.R. diamonds did not end up being correctly classified in Antwerp.

99. A second explanation is that a diamond can move several times from one center to another before being sold to a manufacturer, implying that some diamond exports could be registered as imports more than once. While this could explain why the importbased data arc always somewhat higher than the export-based data, it cannot explain the large increase in the import-based data starting in 1998.

\section{A third explanation is that diamonds from other countries have been classified} in Antwerp as C.A.R. diamonds. For example, since diamonds from non-EU-affiliated countries are subject to a 0.3 percent import tax in Belgium, part of these diamonds may have been recorded as originating from an EU-affiliated country, such as the C.A.R. Goreux (2001, p. 10) mentions Russia as an example of such a non-EU-affiliated diamond-exporting country, while Dietrich (2002, p. 23) cites Brazil and Venezuela, whose diamonds are very similar in quality to C.A.R. diamonds.

${ }^{55}$ Machulka (2002, p. 582). 
Table IV.1 Central African Republic: Estimates of Diamond Exports, 1995-2001

\begin{tabular}{|c|c|c|c|c|c|c|c|}
\hline & 1995 & 1996 & 1997 & 1998 & 1999 & 2000 & 2001 \\
\hline \multicolumn{8}{|l|}{ Export volumes (thousands of carats) } \\
\hline Official C.A.R. diamond exports $1 /$ & 484.3 & 487.4 & 473.4 & 419.9 & 431.1 & 461.0 & 449.3 \\
\hline Reported imports of C.A.R. diamonds $2 /$ & 626.3 & 571.6 & 581.0 & 802.5 & 1241.7 & 1307.7 & 634.3 \\
\hline \multicolumn{8}{|l|}{ Export values (millions of U.S. dollars) } \\
\hline Official C.A.R. diamond exports 1/ & 75.3 & 70.4 & 66.9 & 59.1 & 62.1 & 61.7 & 56.2 \\
\hline Reported imports of C.A.R. diamonds $2 /$ & 88.9 & 113.4 & 107.9 & 155.6 & 155.6 & 160.8 & 96.9 \\
\hline \multicolumn{8}{|l|}{ Unit values (U.S. dollars per carat) } \\
\hline Official C.A.R. diamond exports $1 /$ & 155.6 & 144.5 & 141.3 & 140.7 & 144.1 & 133.9 & 125.2 \\
\hline Reported imports of C.A.R. diamonds $2 /$ & 142.0 & 198.3 & 185.8 & 193.9 & 125.3 & 122.9 & 152.8 \\
\hline
\end{tabular}

Sources: C.A.R. authorities; and Hoge Raad voor de Diamant (Diamond High Council), Antwerp.

1/ Data provided by C.A.R. authorities.

2/ Data provided by Hoge Raad voor de Diamant (Diamond High Council), Antwerp.

101. The most likely explanation of the difference observed between 1998 and 2000 is that C.A.R. diamonds were mixed with "conflict diamonds" diamond-producing Équateur Province was occupied by the MLC (Mouvement de Libération du Congo) starting in 1998. As Dietrich (2002) notes, there is evidence that diamonds from the Équateur Province were sold to C.A.R. traders (possibly in exchange for oil) and reexported as C.A.R. diamonds. Since DRC diamonds have a lower average value per carat than C.A.R. diamonds, this explains why the unit value estimated by Antwerp is significantly lower than the unit value reported by BECDOR, which would otherwise be counterintuitive, given BECDOR's incentives for undervaluation. ${ }^{57}$

56 "Conflict diamonds" are diamonds that are used to finance the activities of rebel groups. While diamonds from Angola and Sierra Leone have been officially classified as such, there is also ample evidence that diamonds have helped to sustain the conflict in the DRC (see, e.g., Parker and others (2000), Goreux (2001), and USAID (2000 and 2001)).

${ }^{57}$ Another possibility is that the extra C.A.R. diamonds included conflict diamonds from Angola, which were subject to a U.N. embargo. Angolan diamonds, however, have a higher unit value than C.A.R. diamonds and, therefore, are less likely to have been involved. 
102. Why did the difference between export-based and import-based data shrink again in 2001? One explanation is that the cross-border trade came to an end when the C.A.R. river company (SOCRATAF) stopped reexporting oil to the Équateur Province after its boats had been subject to frequent attacks. Another explanation is that the certification process for diamonds was widely expected to become much tighter in 2001 , after the UN General Assembly unanimously adopted a resolution in December 2000, cosponsored by 48 states, that expressed the need to address the problem of conflict diamonds by creating and implementing an international certification scheme for rough diamonds. ${ }^{58}$

103. Given the above, the most representative years appear to be those of 1996 and 1997. In those years, the Antwerp data suggest that about 20 percent of diamonds were smuggled, ${ }^{59}$ while the unit value of the remaining diamonds was underestimated by about 25 percent, thus implying a 45 percent underestimation of the total value of diamond exports. While this remains a crude estimate, it comes close to the consensus, noted above, that the value of official C.A.R. diamond exports could double if smuggling and undervaluation were eradicated.

\section{E. Diamond Sector Reforms}

104. With a view to promoting a broad expansion of the country's diamond sector, the C.A.R. authorities are undertaking a number of reforms in order to (i) strengthen artisanal production; (ii) reduce tax evasion; and (iii) attract both foreign and domestic investors. In addition, the World Bank is about to conduct a detailed study of the C.A.R. diamond sector and will suggest additional reforms. This subsection contains an overview of the reforms already carried out or envisaged by the authorities, as well as some preliminary thoughts on additional reforms.

\section{Strengthening artisanal production}

105. In order to strengthen the position of artisans, the C.A.R. authorities are helping to create mining cooperatives. As discussed above, individual artisans are typically unable to borrow because their incomes are highly unstable. It is therefore difficult for them to invest in productivity-increasing equipment. Cooperatives of artisans, however, can pool their risks and borrow the necessary funds to purchase equipment, such as motor pumps or excavators, with which they can increase their productivity and, therefore, their incomes. The number of mining cooperatives has risen in recent years from 5 to 150 , and the authorities

\footnotetext{
${ }^{58}$ For more on this resolution and the associated Kimberley Process, which is establishing international standards for national certification schemes, see the appendix to this section, as well as information available via the Internet: http://www.kimberleyprocess.com

59 This is still an underestimate to the extent that some smuggled C.A.R. diamonds may not have been recorded in Antwerp as such.
} 
were planning, as part of their Mining Sector Development Project (PDSM), to organize an additional 1,000 cooperatives in $2002 .^{60}$

106. As an additional measure to strengthen the position of artisans, the C.A.R. government has established an International Diamond Exchange in Bangui (Bourse Internationale du Diamant de Bangui, or BIDB), in partnership with the British services group, Gemkin (GB). The objective of the exchange is to allow artisans to sell directly to competing international diamond buyers, and thereby to help them obtain a higher price for their diamonds. In its initial phases, the BIDB suffered from several problems, including the difficulty of attracting sufficient numbers of interested buyers and sellers. On the one hand, buyers were hesitant to trade openly, while, on the other hand, many artisans were unable to freely participate in the exchange because of their implicit contracts with particular collectors. However, as Table IV.2 shows, the BIDB has recently grown in importance relative to purchasing bureaus (six of which existed in 2001), and accounted for about 30 percent of total exports in November and December $2001 .^{61}$

107. While cooperatives and the diamond exchange have the potential to significantly strengthen the position of artisans and, hence, decrease the market power of collectors, two important constraints remain. First, in order to truly diminish the dependence of artisans upon collectors, artisans will need to have an alternative source of financing. It would be interesting, therefore, to study the feasibility of setting up microfinance institutions in mining areas. ${ }^{62}$ In addition to being a source of credit, microfinance institutions could be used as a location for depositing currency as well as diamonds. Second, in order to allow more artisans to participate in the diamond exchange, it is important to have a good infrastructure in place. Currently, this condition is not met, as many artisans still work in fairly isolated areas. As long as these two constraints remain, it is to be expected that collectors will continue to play an important role.

\section{Reducing tax evasion}

108. In order to reduce the undervaluation of exported diamonds, the C.A.R. authorities are installing independent valuators to strengthen the activities of BECDOR. ${ }^{63}$

60 See Mwamba (2002, p. 41). The conditions for setting up a cooperative are as follows:

(i) at least ten licensed artisans should participate; (ii the cooperative needs to purchase an artisanal promotion permit (permis de promotion artisanal, or PPA), which costs CFAF 60,000 for two years, and through which control is obtained over an area of 250,000 square meters; and (iii) each cooperative can obtain at most five PPAs.

${ }^{61}$ Machulka (2002).

${ }^{62}$ A further study on this issue would need to specify who could provide the initial capital for the microfinance institutions and who would be operating them.

63 The previous government signed a four-year contract with the Antwerp-based firm 
This principle of "double evaluation" will be accompanied by an electronic tracking system that requires valuators in Antwerp to immediately transmit their valuations electronically (by e-mail) to the authorities in Bangui. ${ }^{64}$ HRD in Antwerp has already designed and installed such tracking systems for other countrics, including Angola and Sierra Leone (USAID, 2000 and 2001), and is working with the C.A.R. authorities to implement a similar system (Mwamba, 2002, p. 41.)

Table IV.2. Central African Republic: Monthly Diamond Exports

by Purchasing Bureaus and the BIDB in 2001

(In carats)

\begin{tabular}{|c|c|c|c|c|c|c|c|c|}
\hline & 1 & 2 & 3 & 4 & 5 & 6 & BIDB & Total \\
\hline April & 783 & 11 & & 7915 & 11,686 & 10,096 & & 30,491 \\
\hline May & & & & 16,968 & 10,356 & 13,248 & 4,295 & 44,867 \\
\hline June & & & & 7,810 & 9,723 & 7,771 & 5,855 & 31,159 \\
\hline July & & 1,139 & & 8,804 & 15,360 & 1 & & 25,304 \\
\hline August & & & & 10,366 & 8,809 & 5,614 & 7,614 & 32,403 \\
\hline September & & & & 5,935 & 8,797 & 7,251 & 3,560 & 25,543 \\
\hline October & & 165 & 755 & 10,261 & 7,910 & 4,349 & 9,986 & 33,426 \\
\hline November & & & & 7,382 & 7,068 & 4,401 & 12,716 & 31,567 \\
\hline December & & & 2,078 & 8,135 & 6,376 & 4,317 & 11,286 & 32,192 \\
\hline Total & 783 & 1,315 & 2,833 & 83,576 & 86,085 & 57,048 & 55,312 & 286,952 \\
\hline
\end{tabular}

Source: International Diamond Exchange in Bangui (BIDB).

109. In order to reduce smuggling, the C.A.R. authorities plan to (i) strengthen the mining police force, which urgently needs new equipment; and (ii) install control offices in the mining regions. ${ }^{65}$ However, as the analysis above shows, controlling smuggling will

Independent Diamond Valuators Ltd. (IDV), which would provide independent expertise on C.A.R. official exports. The IDV also has been seeking an evaluation contract with the DRC government since early 2001 (Dietrich, 2002, p. 23).

${ }^{64}$ Goreux (2001, p. 10) suggests that diamond centers should e-mail the value of diamond imports both to the authorities and to the International Monetary Fund, so as to improve the transparency of financial transactions.

${ }^{65}$ Ministry of Mines, Energy, and Water Resources (2002). 
remain difficult as long as law enforcers are paid low salaries, and as long as the expected benefits from smuggling outweigh the expected costs.

\section{In addition to raising the costs of smuggling by strengthening monitoring and} enforcement, the authorities may wish to consider additional reforms that could reduce the benefits from smuggling. One possibility is to lower the tax rate on diamond exports, which is currently 6 percent, and seems rather high compared with similar diamond exporting countries (see Oomes and Vocke, 2003). However, the authorities are not eager to lower the rate, as past experiences with lowering the export tax rates have yielded rather discouraging results. For example, when the rate was lowered from $71 / 2$ percent to 6 percent in 1998 , reported volumes of diamond exports fell, rather than increased. Moreover, even if the tax rate were reduced, the benefits from smuggling would still exist because of uncompetitive prices paid by purchasing bureaus.

\section{A potentially more effective way to reduce the benefits from smuggling is to} narrow the differential between official and unofficial purchasing prices by increasing competition among the purchasing bureaus of export companies. While increased competition has been partly established by the BIDB, as discussed above, the remaining barriers to entry could be reduced by, for example, lowering the required installation costs for purchasing bureaus. In addition, competition among purchasing bureaus could be increased by lowering the barriers to entry for collectors (i.e., by lowering or eliminating their license fees, and by making altcrnative sources of financing available to collectors). By reducing their need for financing, collectors would have less of an incentive to agree to implicit contracts that oblige them to sell to one particular purchasing bureau. ${ }^{66}$

\section{Attracting foreign and domestic investment}

\section{The C.A.R. government intends to attract foreign investors by creating an} attractive legal, institutional, and fiscal framework. Particular emphasis will be placed on strengthening the country's capacities for promoting research, in order to optimize the profitability of this sector while respecting the environment. ${ }^{67}$

\section{Perhaps the main reason why diamonds have failed to enrich the Central} African Republic is that no processing takes place in the country itself; as a result, the bulk of potential value added accrues to the rest of the world. A national diamond-polishing facility used to operate in the Central African Republic but went bankrupt after the French military left in 1996, which led to a significant decrease in local demand for polished

\footnotetext{
${ }^{66}$ However, the current dependency of collectors upon purchasing bureaus plays a role in the reduction of smuggling, as it forces collectors to sell their diamonds through official channels. If collectors were less dependent on purchasing bureaus, therefore, smuggling could increase rather than decrease.
}

${ }^{67}$ Ministry of Mines, Energy, and Water Resources (2002). 
diamonds. At present, virtually all C.A.R. diamonds are exported in rough form and are cut and polished abroad. The value added during each stage of this production process is given in Table IV.3, which lists the total (world) value of diamonds and jewelry at various stages. According to these data, a country that exports only rough diamonds obtains about oneeighth of all value added. The value of rough diamonds approximately doubles once they have been polished, doubles again when they have been manufactured into jewelry, and doubles once more in the process of marketing the jewelry to consumers.

Table IV.3. Central African Republic: Value Added in Jewelry Production (In billions of U.S. dollars)

\begin{tabular}{lcc}
\hline Product & 1999 Value & Value Added \\
\hline & 7 & 7 \\
Rough diamonds & 14 & 7 \\
Polished diamonds & 28 & 14 \\
Jewelry (production costs) & 56 & 28 \\
Jewelry (consumer prices) & & \\
\hline
\end{tabular}

Sourccs: Mining Journal; and Goreux (2001).

114. Table IV.3 suggests that the value added within the country could be almost doubled if C.A.R. diamonds were exported in cut (polished) form. Investment in diamond-cutting facilities, however, has been discouraged for several reasons: (i) the cost of cutters is high; (ii) the time necessary to train cutters is long (four years); and (iii) it is difficult to obtain sufficient rough material. The first two problems could be minimized if automated diamond-cutting procedures could be established, which would require significant investment by foreign cutting firms. The third problem arises because, in order to be able to buy rough diamonds, a potential investor would be subject to the same requircments as the purchasing bureaus of export companies. Moreover, the existing purchasing bureaus would not have an incentive to sell to local polishing facilities, as they already have their own polishing facilities abroad. ${ }^{68}$

115. In order to stimulate investment in diamond-cutting facilities, the C.A.R. authorities could consider granting such facilities the right to purchase diamonds directly from (cooperatives of) artisans, for example by means of the BIDB. This could be advantageous for both artisans and investors, as they could share the surplus otherwise earned by collectors and the purchasing bureaus. Ilowever, as mentioned abovc, this

${ }^{68}$ In the past, this problem was solved by requiring purchasing bureaus to sell 5 percent of their export volume to the national diamond-cutting facility. 
approach would work best if artisans had their own source of financing, enabling them to sell to whomever they wanted. 


\section{References}

Dietrich, Christian, 2002, Hard Currency: The Criminalized Diamond Economy of the Democratic Republic of the Congo and its Neighbours, Occasional Paper No. 4, Diamonds and Human Security Project (Ottawa: Partnership Africa Canada).

Economist, 2000, “Diamond King,” January 27.

Economist, 2002, “Conflict Diamonds: Smuggling Is Easy," March 16.

Goreux, Louis, 2001, “Conflict Diamonds," Africa Region Working Paper, No. 13 (Washington: World Bank).

Harris, J.M., 2001, “Central African Republic," in Mining Annual Review 2001 (London: Mining Journal Ltd.).

Jones, Lucy, 2002a, "Mixed Blessing of Diamonds in CAR," BBC News (London), February 4. Available via the internet: http://news.bbc.co.uk/ ,2002b, "Tranquility and Trade Pump Life Back Into Africa's Heart, Guardian Weekly (Manchester), March 21. July 25.

Machulka, David (2002), "Diamants: un secteur mal maîtrisé," Marchés Tropicaux (Spécial Centrafrique) (Paris), March 15, pp. 581-82.

Ministry of Mines, Energy, and Water Resources, 2002, "Le Secteur Minier Centrafricain" (Bangui, Central African Republic: Ministry of Mines, Energy, and Water Resources).

Mwamba, Bapuwa, 2002, "Centrafrique: Au Coeur de la Tourmente," Jeune Afrique Économie (Paris), No. 337, January 4-February 17, pp. 40-41.

Oomes, Nienke, and Matthias Vocke (2003), "Diamond Smuggling and Taxation in SubSaharan Africa," IMF Working Paper No. 03/167 (Washington: International Monetary Fund).

Parker, Andrew, and others, 2000, "Fatal Transactions," Financial Times (London), July 12.

Rombouts, Luc, 2000, Diamond Annual Review 2000. Available via the Internet: http://www.terraconsult.com

USAID, 2000, "Diamonds and Armed Conflict in Sierra Leone: Proposal for Implementation of a New Diamond Policy and Operations" (Washington: U.S. Agency for International Development, Office of Transition Initiatives). Available via the Internet: http:/www.usaid.gov/hum_response/oti/country/sleone/diamonds.html ,2001, "Sierra Leone: 'Conflict' Diamonds," Progress Report on Diamond Policy and Development Program (Washington: U.S. Agency for International Development, Office of Transition Initiatives). Available via the Internet: http:/www.usaid.gov/hum_response/oti/country/sleone/confdiam.html. 


\section{The C.A.R. and the Kimberley Process ${ }^{69}$}

The Kimberley Process, launched in May 2000, is an initiative which aims at breaking the link between resource wealth and conflict by preventing the trade in conflict diamonds, notably through an international certification scheme for diamond exports- the Kimberley Process Certification Schcmc (KPCS) - that was adopted in November 2002 and began implementation on January 1, 2003. The initiative involves diamond companies and trading countries, and requires diamond exports to be accompanied by a certificate issued by producing-country governments indicating that they are conflict free. It also requires participants to collect information on official diamond production, import, and export data. There are currently forty-five states and one regional economic integration organization, the European Community, participating in the KPCS. An additional twenty states have expressed interest in participating in the KPCS and are putting in place the necessary arrangements to meet the requirements of the certification scheme. ${ }^{70}$

The C.A.R. became a participant in the Kimberley Process at end-2001 and has since February 2002 benefited from the assistance of the Antwerp-based firm Independent Diamond Valuators Ltd. (IDV), both for the valuation of diamond exports and the certification process. Largely because of concerns about the country's diamond industry following the March 2003 coup d'état, including calls from nongovernmental organizations and the World Diamond Council to suspend the C.A.R. from the Kimberley Process, a KPCS review mission visited the country in June 2003 to assess the effectiveness of control measures. The mission concluded that the C.A.R. was able to implement the certification scheme satisfactorily but encouraged the further strengthening of internal monitoring and controls. Subsequently, the C.A.R. was chosen to represent African countries in the Monitoring and Review Commission of the KPCS. Other members of the commission include the United States, Russia, India, South Africa, and Australia.

The authorities indicated that efforts to reduce illegal exports of diamonds would depend not only on their own efforts to improve the monitoring of exports, but also on the participation of neighboring countries in the KPCS. They pointed out that they would be one of the chief beneficiaries of broader participation in the KPCS, as taxes on diamond exports were lower in neighboring countries, and this was one of the main reasons for the smuggling of diamonds from the C.A.R.. Following the adoption of their new mining code, the authorities also intend to contact bilateral donors to receive technical assistance aimed at enhancing their monitoring and control procedures, notably with regard to the classification of diamonds and the accuracy of statistical reporting. In spite of their limited administrative capacity, they also indicated their readiness to share their expertise with new participants in the KPCS.

${ }^{69}$ This appendix was prepared by Ragnar Gudmundsson.

${ }^{70}$ For more information, see the website at www.kimberleyprocess.com. 


\section{Recent Social Developments and Poverty Reduction Focus ${ }^{71}$}

116. As noted above, the C.A.R., with a GNP per capita of US\$346 (constant 1995 U.S. dollars) in $2000,{ }^{72}$ is among the ten least-developed countries in the world. Increasing poverty and disintegration of social structures have contributed to an increase in the incidence of communicable diseases, including malaria, diarrhea, and HIV/AIDS. The number of people infected with HIV has been increasing steadily since the identification of the first cases of AIDS in the mid-1980's. The recent political and military events had a grim impact on social conditions, which, on the basis of anecdotal information, worsened further during the October 2002-March 2003 period. The civil conflict dramatically worsened the already insufficient provision of public health, education, and HIV/AIDS treatment and prevention. Recent estimates indicate that the rate of HIV/AIDS prevalence among adults has increased to more than about 15 percent, placing the Central African Republic as the tenthmost HIV-infected country in sub-Saharan Africa. HIV/AIDS and its related opportunistic infections have become a serious threat to the economic and social development of the country.

117. In recent years, the government of the C.A.R. has expressed a commitment to poverty alleviation. In 1998-99, it developed, with assistance from the United Nations Development Program (UNDP), a National Poverty Plan (NPRP), which was discussed at a national seminar in August 1999. In preparing the plan, the government consulted important stakeholders, including village leaders, women's and youth associations, religious organizations, trade unions, and nongovernmental organizations (NGOs).

118. Building on the NPRP, an interim Poverty Reduction Strategy Paper (PRSP) was prepared by a technical committee in collaboration with representatives from employers' associations, trade unions, and local NGOs. The C.A.R.'s interim PRSP was finalized and presented to the Board of the IMF in January 2001. The interim PRSP identified the key weaknesses of the NPRP, and established a work program for fully addressing these weaknesses in the preparation of the full PRSP. These weaknesses included an inadequate databasc on poverty, lack of prioritization of economic and social policies, limited consultations with the population, and lack of an integration of the poverty reduction strategy with a medium-term macroeconomic framework. The interim PRSP emphasized the importance of rapid and broad-based economic growth, accompanied by a stable macroeconomic framework as a prerequisite for poverty reduction. However, the interim PRSP did not set poverty reduction goals along the lines of the background of the Millennium Development Goals (MDG), and did not discuss a macroeconomic framework beyond 2001.

${ }^{71}$ This section was prepared by Dhaneshwar Ghura, Abdoulaye Seck, and Giorgia Albertin.

${ }^{72}$ World Bank, World Development Indicators, 2003. 
119. The interim PRSP was candid in identifying poor governance and inadequate security as major constraints to the fight against poverty. The strategy presented in the interim PRSP focused on poverty reduction via broad-based and equitable growth, based on private sector development. To this end, it stressed the importance of having a stable macroeconomic environment, to be achieved through enhanced revenue collection, the improvement of public expenditure management, and the fight against corruption. It also stressed the improvement of access to basic education and health services, as well as curbing the prevalence of HIV/AIDS and malaria, and it underscored the need to extend basic social and productive infrastructures to rural and poor urban areas. Improving security, promoting good governance, decentralizing government, strengthening institutions, and mobilizing the collaboration of local communities were presented as necessary conditions for the effective implementation of a poverty reduction strategy.

120. The Joint Staff Assessment (JSA) of the interim PRSP, prepared by the staffs of the World Bank and the Fund, praised the government's efforts to prepare an adequate interim PRSP despite limited technical capacity, financial resources, and poverty data. Nonetheless, the JSA stressed that the PRSP would need to address weaknesses observed in the preparation of the interim PRSP. In particular, the work leading to the preparation of the PRSP would need to improve the statistical database; strengthen the participatory process; better prioritize the objectives for poverty reduction; clearly define quantitative targets for poverty reduction in the context of a detailed costing and financing exercise; and design an effective system for monitoring progress in reducing poverty, including the tracking of poverty outlays.

121. Since the presentation of the C.A.R.'s interim PRSP, the government continued the preparation of the full PRSP, but progress has been notably slow owing to the political and military events, the lack of financial resources, and inadequate analytical and management capacities. However, recently, some steps forward have been realized, and the C.A.R. authorities anticipate the completion of the full PRSP in December 2004. In this context, household surveys in rural and urban areas have been undertaken to assess the poverty conditions in the C.A.R.. Furthermore, progress in the definition of strategic objectives and a monitoring mechanism has been achieved through the elaboration of action plans for the sectors and the organization of a national workshop to validate the poverty data. However, much work remains for the completion of the full PRSP, including the analysis of the household surveys, the preparation of the notes on the determinants of poverty and economic growth, the preparation of the note on the participatory process, the costing of the programs and strategies for poverty reduction, and aligning the poverty strategy and programs with the macroeconomic framework, including public expenditure programs. 
Central African Republic: Basic Data

Area, population, and income per capita (2002 estimates) 1/

$\begin{array}{lr}\text { Area } & 623,000 \\ \text { Population } & \\ \text { Total } & 3.9 \text { million } \\ \text { Growth rate } & 2.0 \text { percent } \\ \text { GNP per capita } & \text { US } \$ 3462 /\end{array}$

$\begin{array}{lllllll}1997 & 1998 & 1999 & 2000 & 2001 & 2002 & 2003\end{array}$

Est.

Gross domestic product and

expenditure at current prices

Gross domestic product

Primary sector

Secondary sector

Tertiary sector

Indirect taxes net of subsidies

Gross domestic expenditure

Consumption

Gross capital formation

Net exports of goods and services

Prices

GDP deflator

Consumer prices in Bangui

Central government operations

Total revenue

Total expenditure

Current expenditure

Capital expenditure

Overall balance, commitments basis

Of which: primary balance, excluding foreign financed investment

Net change in arrears

Overall balance, cash basis

Financing

Foreign financing, net

Domestic financing, net

Total revenue

Total expenditure

Overall balance, commitments basis

Of which: primary balance, excluding foreign financed investment

(In billions of CFA francs)

$\begin{array}{rrrrrrr}566.0 & 606.4 & 638.7 & 683.1 & 709.2 & 726.2 & 696.4 \\ 285.0 & 311.0 & 315.7 & 341.4 & 365.2 & 370.4 & 378.8 \\ 82.8 & 85.8 & 93.4 & 101.6 & 105.0 & 104.1 & 98.5 \\ 167.6 & 173.2 & 190.7 & 199.3 & 202.3 & 207.5 & 187.9 \\ 30.7 & 36.4 & 38.9 & 40.8 & 36.6 & 44.2 & 31.2 \\ & & & & & & \\ 583.6 & 650.8 & 668.0 & 716.1 & 741.0 & 757.6 & 734.8 \\ 542.2 & 58.3 .3 & 593.1 & 651.1 & 681.8 & 692.5 & 692.9 \\ 41.4 & 67.5 & 74.9 & 65.0 & 59.3 & 65.1 & 41.9 \\ -17.5 & -44.4 & -29.4 & -33.0 & -31.8 & -31.3 & -38.4\end{array}$

(Index, $1990=100)$

$\begin{array}{lllllll}97.5 & 98.7 & 97.3 & 100.5 & 99.1 & 98.6 & 99.0\end{array}$

$\begin{array}{lllllll}146.5 & 143.7 & 141.7 & 146.2 & 151.8 & 155.3 & 161.8\end{array}$

(In billions of (FA francs)

$\begin{array}{rrrrrrr}45.0 & 56.3 & 59.7 & 60.5 & 63.2 & 78.4 & 53.7 \\ 81.9 & 109.5 & 116.1 & 105.7 & 93.6 & 114.6 & 85.5 \\ 51.2 & 50.2 & 54.5 & 63.1 & 60.9 & 68.6 & 66.0 \\ 30.7 & 59.3 & 61.6 & 42.6 & 32.8 & 46.0 & 19.5 \\ -36.8 & -53.1 & -56.3 & -45.2 & -30.5 & -36.2 & -31.8 \\ -2.7 & 3.8 & -2.5 & -1.4 & 2.5 & 7.6 & -14.9 \\ 20.6 & -70.1 & -3.0 & -2.9 & -7.3 & 21.3 & 28.4 \\ -16.3 & -123.2 & -59.3 & -48.1 & -37.7 & -14.8 & -3.5 \\ 16.3 & 46.8 & 44.3 & 35.1 & 31.3 & 14.8 & 3.5 \\ 18.7 & 43.3 & 41.0 & 26.4 & 20.1 & 14.5 & -1.3 \\ -2.4 & 3.5 & 3.3 & 8.8 & 11.2 & 0.4 & 4.8\end{array}$

(In percent of GDP)

$\begin{array}{rrrrrrr}8.0 & 9.3 & 9.4 & 8.9 & 8.9 & 10.8 & 7.7 \\ 14.5 & 18.1 & 18.2 & 15.5 & 13.2 & 15.8 & 12.3 \\ -6.5 & -8.8 & -8.8 & -6.6 & -4.3 & -5.0 & -4.6 \\ -0.5 & 0.6 & -0.4 & -0.2 & 0.3 & 1.0 & -2.1\end{array}$


Central African Republic: Basic Data (concluded)

$\begin{array}{lllllll}1997 & 1998 & 1999 & 2000 & 2001 & 2002 & 2003\end{array}$

Monetary survey

Net foreign assets

Net domestic assets

Claims on the public sector, net

Net other items

Money and quasi money

Balance of payments

Current account balance

Balance of goods

Exports, f.o.b.

Imports, f.o.b.

Services, net

Income, net

Capital account

Financial account

Overall balance

Exchange rates

Nominal effective exchange rate

CFA francs per U.S. dollar

Period average

End of period

CFA francs per SDR

Period average

End of period

Social indicators $1 /$

Population (millions)

Fertility rate (births per woman)

Life expectancy at birth (years)

Infant mortality rate (per thousand)

Uider 5 mortality rate (per thousand)

Illiteracy rate, adult male (percent)

Illiteracy rate, adult female (percent)

Primary school enrollment (percent)
Credit to the economy

Current transfers, net

Real effective exchange rate

$-21.2$

12.0

114.1

$-102.2$

$-33.8$

$-11.9$

12.6

14.5

$-50.0$

$-33.5$

$-43.2$

$-39.4$

$-45.6$

3.4

111.3

$-107.9$

$-58.8$

$-9.6$

19.5

41.9

31.7

$-39.5$

$-33.2$

$-13.7$

$-13.7$

63.7

55.7

48.7

31.3

34.8

31.4
39.5

46.0

49.2

54.6

50.2

51.2

40.3

38.9

42.5

49.4

55.2

$-43.8$

$-51.1$

$-50.3$

48.0

105.3

110.9

109.7

104.9

$-52.0$

99.9

(In millions of SDRs)

$\begin{array}{rrrrr}-12.8 & -22.1 & -19.2 & -19.3 & -41.0 \\ 12.3 & 28.4 & 27.5 & 21.8 & 6.2 \\ 108.4 & 118.4 & 111.6 & 112.6 & 83.8 \\ -96.1 & -90.1 & -84.2 & -90.8 & -77.5 \\ -47.2 & -63.7 & -61.6 & -56.6 & -53.5 \\ -7.5 & -12.7 & -8.0 & -5.6 & -2.7 \\ 29.7 & 26.0 & 22.9 & 21.1 & 8.9 \\ & & & & \\ 31.7 & 17.8 & 14.0 & 15.1 & 8.5 \\ & & & & \\ -39.5 & -33.2 & -8.5 & -33.5 & -16.4 \\ & & & & \\ -13.7 & -13.7 & -29.7 & -40.4 & -38.8\end{array}$

(Index, 1990=100, unless otherwise indicated)

$\begin{array}{rrrrrrr}97.1 & 98.2 & 97.9 & 98.0 & 103.2 & 106.7 & 111.1 \\ 62.9 & 61.3 & 58.1 & 56.6 & 58.5 & 60.5 & 63.7 \\ & & & & & & \\ 583.7 & 590.0 & 614.9 & 710.1 & 732.4 & 694.8 & 580.1 \\ 585.1 & 562.2 & 653.0 & 705.0 & 744.3 & 652.4 & 540.5 \\ & & & & & & \\ 803.2 & 800.3 & 840.7 & 936.5 & 932.3 & 899.7 & 811.2 \\ 789.4 & 791.6 & 896.2 & 918.5 & 935.4 & 887.0 & 803.1\end{array}$

(In units indicated)

\begin{tabular}{rrrrrrr}
3.5 & 3.6 & 3.7 & 3.7 & 3.8 & 3.9 & 3.9 \\
4.9 & $\ldots$ & $\ldots$ & 4.7 & 4.7 & $\ldots$ & $\ldots$ \\
45.1 & $\ldots$ & 44.1 & 43.5 & $\ldots$ & $\ldots$ & $\ldots$ \\
115.0 & $\ldots$ & $\ldots$ & 115.0 & 115.0 & $\ldots$ & $\ldots$ \\
148.0 & $\ldots$ & $\ldots$ & 180.0 & 180.0 & $\ldots$ & $\ldots$ \\
44.1 & 42.8 & 41.5 & 40.3 & 39.2 & $\ldots$ & $\ldots$ \\
69.6 & 68.1 & 66.6 & 65.1 & 63.4 & $\ldots$ & $\ldots$ \\
60.0 & 73.0 & $\ldots$ & 75.0 & $\ldots$ & $\ldots$ & $\ldots$ \\
\hline
\end{tabular}

Sources: C.A.R. authorities; and staff Fund estimates.

1/ Source: World Bank, World Development Indicators, 2003.

2/ 2000 data. 
Table 1. Central African Republic: Gross Domestic Product at Current Prices, 1997-2003

(In billions of CFA francs)

\begin{tabular}{|c|c|c|c|c|c|c|c|}
\hline & 1997 & 1998 & 1999 & 2000 & 2001 & 2002 & $\begin{array}{r}2003 \\
\text { Est. }\end{array}$ \\
\hline Primary sector & 285.0 & 311.0 & 315.7 & 341.4 & 365.2 & 370.4 & 378.8 \\
\hline Agriculture & 159.9 & 172.7 & 171.5 & 174.3 & 195.2 & 197.4 & 208.1 \\
\hline Subsistence & 150.8 & 162.6 & 161.8 & 165.1 & 185.7 & 193.2 & 206.7 \\
\hline Cash crops & 9.0 & 10.0 & 9.7 & 9.2 & 9.5 & 4.2 & 1.4 \\
\hline Livestock & 61.2 & 64.8 & 66.6 & 71.3 & 76.9 & 80.7 & 82.9 \\
\hline Hunting and fishing & 28.7 & 30.4 & 31.3 & 33.5 & 36.0 & 38.6 & 40.3 \\
\hline Hunting & 18.5 & 19.6 & 20.2 & 21.6 & 23.2 & 24.9 & 26.0 \\
\hline Fishing & 10.2 & 10.8 & 11.1 & 11.9 & 12.8 & 13.7 & 14.3 \\
\hline Forestry & 35.2 & 43.2 & 46.3 & 62.3 & 57.2 & 53.7 & 47.4 \\
\hline Logs & 21.0 & 24.7 & 29.4 & 38.4 & 33.6 & 32.4 & 27.0 \\
\hline Other & 14.2 & 18.5 & 16.9 & 23.9 & 23.5 & 21.3 & 20.5 \\
\hline Secondary sector & 82.8 & 85.8 & 93.4 & 101.6 & 105.0 & 104.1 & 98.5 \\
\hline Manufacturing industry & 22.6 & 20.3 & 21.7 & 24.9 & 24.6 & 21.5 & 16.1 \\
\hline Mining & 35.4 & 38.6 & 42.0 & 44.8 & 46.0 & 47.7 & 46.1 \\
\hline Public utilities & 4.3 & 4.5 & 4.8 & 5.2 & 5.4 & 5.2 & 5.4 \\
\hline Construction & 20.5 & 22.4 & 24.9 & 26.7 & 29.0 & 29.7 & 30.9 \\
\hline Tertiary sector & 167.6 & 173.2 & 190.7 & 199.3 & 202.3 & 207.5 & 187.9 \\
\hline Merchant services & 106.2 & 112.3 & 122.4 & 128.9 & 140.7 & 142.5 & 136.4 \\
\hline Transport and communications & 20.4 & 21.6 & 24.2 & 25.6 & 26.8 & 27.9 & 26.6 \\
\hline Commerce & 56.7 & 59.8 & 64.8 & 68.2 & 75.2 & 75.7 & 72.3 \\
\hline Other & 29.2 & 30.8 & 33.4 & 35.1 & 38.7 & 39.0 & 37.6 \\
\hline Nonmerchant services & 61.3 & 60.9 & 68.3 & 70.4 & 61.6 & 65.0 & 51.5 \\
\hline Central government & 36.3 & 36.1 & 36.0 & 39.4 & 39.8 & 45.1 & 47.0 \\
\hline Technical assistance & 25.0 & 24.8 & 32.3 & 31.0 & 21.8 & 19.9 & 4.5 \\
\hline GDP at factor costs & 535.4 & 570.0 & 599.8 & 642.3 & 672.6 & 682.1 & 665.2 \\
\hline Indirect taxes & 25.3 & 30.9 & 33.5 & 34.2 & 29.6 & 36.5 & 23.6 \\
\hline Customs duties & 5.4 & 5.5 & 5.4 & 6.6 & 7.0 & 7.6 & 7.7 \\
\hline GDP at market prices & 566.0 & 606.4 & 638.7 & 683.1 & 709.2 & 726.2 & 696.4 \\
\hline
\end{tabular}

Sources: C.A.R. authorities; and Fund staff estimates. 
Table 2. Central African Republic: Gross Domestic Product

at Previous Year's Prices, 1997-2003 1/

(In billions of CFA francs)

\begin{tabular}{|c|c|c|c|c|c|c|c|}
\hline & 1997 & 1998 & 1999 & 2000 & 2001 & 2002 & $\begin{array}{r}2003 \\
\text { Est. }\end{array}$ \\
\hline Primary sector & 281.1 & 303.2 & 314.0 & 325.8 & 360.9 & 362.9 & 361.7 \\
\hline Agriculture & 158.0 & 168.4 & 172.1 & 168.5 & 186.9 & 194.5 & 197.8 \\
\hline Subsistence & 148.5 & 158.7 & 162.2 & 158.9 & 177.3 & 189.4 & 196.5 \\
\hline Cash crops & 9.5 & 9.7 & 10.0 & 9.6 & 9.5 & 5.1 & 1.3 \\
\hline Livestock & 60.3 & 63.1 & 66.7 & 68.6 & 73.4 & 77.2 & 81.3 \\
\hline Hunting and fishing & 28.3 & 29.6 & 31.3 & 32.2 & 34.4 & 36.9 & 39.5 \\
\hline Hunting & 18.3 & 19.1 & 20.2 & 20.8 & 22.2 & 23.8 & 25.5 \\
\hline Fishing & 10.0 & 10.5 & 11.1 & 11.4 & 12.2 & 13.1 & 14.0 \\
\hline Forestry & 34.6 & 42.1 & 43.9 & 56.5 & 66.3 & 54.3 & 43.2 \\
\hline Logs & 20.6 & 24.1 & 27.8 & 34.7 & 38.1 & 33.3 & 23.4 \\
\hline Others & 14.0 & 18.0 & 16.0 & 21.8 & 28.2 & 21.1 & 19.7 \\
\hline Secondary sector & 81.1 & 82.5 & 90.5 & 97.2 & 104.0 & 103.5 & 95.9 \\
\hline Manufacturing industry & 22.2 & 19.5 & 21.3 & 23.2 & 25.6 & 22.6 & 16.7 \\
\hline Mining & 34.8 & 37.1 & 40.4 & 43.2 & 45.5 & 46.6 & 44.3 \\
\hline Public utilities & 4.2 & 4.3 & 4.7 & 4.9 & 5.3 & 5.4 & 5.2 \\
\hline Construction & 19.9 & 21.5 & 24.2 & 25.8 & 27.6 & 29.0 & 29.7 \\
\hline Tertiary sector & 163.6 & 166.1 & 185.0 & 189.1 & 186.3 & 198.0 & 185.0 \\
\hline Merchant services & 103.7 & 107.9 & 118.1 & 126.2 & 129.7 & 138.1 & 135.1 \\
\hline Transport and communications & 19.9 & 20.8 & 22.9 & 25.1 & 24.7 & 27.0 & 26.3 \\
\hline Commerce & 55.3 & 57.5 & 62.8 & 66.8 & 69.3 & 73.4 & 71.5 \\
\hline Others & 28.5 & 29.6 & 32.3 & 34.4 & 35.7 & 37.7 & 37.2 \\
\hline Nonmerchant services & 60.0 & 58.2 & 66.9 & 62.8 & 56.6 & 59.9 & 49.9 \\
\hline Central government & 35.1 & 36.1 & 35.6 & 37.1 & 36.6 & 41.5 & 45.6 \\
\hline Technical assistance & 24.9 & 22.1 & 31.3 & 25.8 & 20.0 & 18.3 & 4.4 \\
\hline GDP at factor costs & 525.8 & 551.7 & 589.5 & 612.0 & 651.2 & 664.4 & 642.6 \\
\hline Indirect taxes & 24.4 & 30.9 & 33.1 & 32.2 & 27.2 & 33.6 & 22.8 \\
\hline Customs duties & 5.2 & 5.5 & 5.3 & 6.2 & 6.4 & 7.0 & 7.4 \\
\hline GDP at market prices & 555.5 & 588.1 & 628.0 & 650.4 & 684.9 & 705.1 & 672.9 \\
\hline
\end{tabular}

Sources: C.A.R. authorities; and Fund staff estimates.

1/ Since the base year (1985) is outdated and being updated, the C.A.R. authorities compute real GDP growth by comparing output at previous year prices (Table 1) with previous year's output at current prices. 
Table 3. Central African Republic: Gross Domestic Product, Real Growth Rates, 1997-2003 1/ (Annual percentage changes)

\begin{tabular}{|c|c|c|c|c|c|c|c|}
\hline & 1997 & 1998 & 1999 & 2000 & 2001 & 2002 & $\begin{array}{r}2003 \\
\text { Est. }\end{array}$ \\
\hline Primary sector & 8.7 & 6.4 & 1.0 & 3.2 & 5.7 & -0.6 & -2.3 \\
\hline Agriculture & 7.2 & 5.3 & -0.3 & -1.8 & 7.2 & -0.4 & 0.2 \\
\hline Subsistence & 7.0 & 5.2 & -0.3 & -1.8 & 7.4 & 2.0 & 1.7 \\
\hline Cash crops & 10.5 & 7.8 & -0.5 & -1.1 & 3.8 & -46.8 & -69.4 \\
\hline Livestock & 3.0 & 3.0 & 3.0 & 3.0 & 3.0 & 0.5 & 0.7 \\
\hline Hunting and fishing & 4.0 & 3.0 & 3.0 & 3.0 & 2.7 & 2.6 & 2.5 \\
\hline Hunting & 4.0 & 3.0 & 3.0 & 3.0 & 2.7 & 2.6 & 2.5 \\
\hline Fishing & 4.0 & 3.0 & 3.0 & 3.0 & 2.7 & 2.6 & 2.5 \\
\hline Forestry & 35.6 & 19.6 & 1.6 & 22.0 & 6.4 & -5.0 & -19.7 \\
\hline Logs & 50.9 & 14.9 & 12.5 & 18.0 & -0.7 & -1.1 & -27.7 \\
\hline Other & 18.0 & 26.5 & -13.1 & 28.9 & 17.7 & -10.6 & -7.5 \\
\hline Secondary sector & -2.8 & -0.3 & 5.6 & 4.0 & 2.4 & -1.4 & -7.9 \\
\hline Manufacturing industry & -1.1 & -13.8 & 5.1 & 6.9 & 2.6 & -9.5 & -22.4 \\
\hline Mining & -10.0 & 5.0 & 4.5 & 3.0 & 1.7 & 1.3 & -7.0 \\
\hline Public utilities & -4.0 & 1.0 & 4.5 & 3.0 & 1.7 & -2.5 & -1.1 \\
\hline Construction & 11.0 & 5.0 & 8.0 & 3.5 & 3.4 & 0.0 & 0.0 \\
\hline Tertiary sector & 9.2 & -0.9 & 6.8 & -0.9 & -6.5 & -2.2 & -10.9 \\
\hline Merchant services & 1.2 & 1.6 & 5.2 & 3.1 & 0.6 & -1.9 & -5.2 \\
\hline Transport and communications & 2.0 & 2.0 & 6.0 & 3.7 & -3.6 & 0.7 & -5.5 \\
\hline Commerce & 1.5 & 1.5 & 5.0 & 3.0 & 1.7 & -2.5 & -5.5 \\
\hline Other & 0.0 & 1.5 & 5.0 & 3.0 & 1.7 & -2.5 & -4.5 \\
\hline Nonmerchant services & 26.6 & -5.2 & 9.8 & -8.0 & -19.7 & -2.8 & -23.2 \\
\hline Central government & 1.8 & -0.7 & -1.4 & 2.9 & -7.2 & 4.3 & 1.0 \\
\hline Technical assistance & 93.1 & -11.7 & 26.0 & -20.3 & -35.5 & -15.8 & -78.1 \\
\hline GDP at factor costs & 6.9 & 3.1 & 3.4 & 2.0 & 1.4 & -1.2 & -5.8 \\
\hline Indirect taxes & 60.4 & 22.4 & 7.2 & -4.0 & -20.5 & 13.6 & -37.5 \\
\hline Customs duties & -45.8 & 1.3 & -3.7 & 15.7 & -2.5 & 0.5 & -2.8 \\
\hline GDP at market prices & 7.5 & 3.9 & 3.6 & 1.8 & 0.3 & -0.6 & -7.3 \\
\hline
\end{tabular}

Sources: C.A.R. authorities; BEAC; and Fund staff estimates.

1/ Since the base year (1985) is outdated and being updated, the C.A.R. authorities compute real GDP growth by comparing output at previous year prices (Table 1) with previous year's output at current prices. 
Table 4. Central African Republic: Supply and Use of Resources at Current Prices, 1997-2003

\begin{tabular}{|c|c|c|c|c|c|c|c|}
\hline & 1997 & 1998 & 1999 & 2000 & 2001 & 2002 & $\begin{array}{r}2003 \\
\text { Est. }\end{array}$ \\
\hline & \multicolumn{7}{|c|}{ (In billions of CFA francs) } \\
\hline Aggregate supply & 724.4 & 773.6 & 786.3 & 848.8 & 858.2 & 870.4 & 812.3 \\
\hline GDP & 566.0 & 606.4 & 638.7 & 683.1 & 709.2 & 726.2 & 696.4 \\
\hline Imports of goods and services & 158.3 & 167.2 & 147.6 & 165.7 & 149.0 & 144.2 & 115.9 \\
\hline Aggregate demand & 583.6 & 650.8 & 668.0 & 716.1 & 741.0 & 757.6 & 734.8 \\
\hline Consumption $1 /$ & 542.2 & 583.3 & 593.1 & 651.1 & 681.8 & 692.5 & 692.9 \\
\hline Central government & 80.9 & 86.1 & 95.4 & 95.6 & 84.4 & 93.7 & 72.7 \\
\hline Private sector & 461.2 & 497.2 & 497.7 & 555.5 & 597.4 & 598.8 & 620.2 \\
\hline Gross fixed capital formation & 41.4 & 67.5 & 74.9 & 65.0 & 59.3 & 65.1 & 41.9 \\
\hline Central government & 23.0 & 44.5 & 46.2 & 32.0 & 24.6 & 34.5 & 14.6 \\
\hline Private sector & 18.4 & 23.0 & 28.7 & 33.1 & 34.7 & 30.5 & 27.3 \\
\hline Changes in stocks & 0.0 & 0.0 & 0.0 & 0.0 & 0.0 & 0.0 & 0.0 \\
\hline Exports of goods and services & 140.8 & 122.8 & 118.3 & 132.7 & 117.2 & 112.9 & 77.5 \\
\hline Resource gap & -158.3 & -167.2 & -147.6 & -165.7 & -149.0 & -144.2 & -115.9 \\
\hline Gross domestic savings & 23.9 & 23.1 & 45.6 & 32.0 & 27.5 & 33.7 & 3.5 \\
\hline Central government & -7.7 & -1.8 & -2.1 & -3.0 & 2.6 & 5.7 & -12.3 \\
\hline Private sector & 31.6 & 24.8 & 47.6 & 35.0 & 24.9 & 28.1 & 15.8 \\
\hline National savings & 24.4 & 31.0 & 64.2 & 44.4 & 41.4 & 47.6 & 8.6 \\
\hline Memorandum items: & \multicolumn{7}{|c|}{ (In percent of GDP) } \\
\hline National savings & 4.2 & 3.8 & 7.1 & 4.7 & 3.9 & 4.6 & 0.5 \\
\hline Central government & -1.4 & -0.3 & -0.3 & -0.4 & 0.4 & 0.8 & -1.8 \\
\hline Private sector & 5.6 & 4.1 & 7.5 & 5.1 & 3.5 & 3.9 & 2.3 \\
\hline Consumption $1 /$ & 95.8 & 96.2 & 92.9 & 95.3 & 96.1 & 95.4 & 99.5 \\
\hline Central government & 14.3 & 14.2 & 14.9 & 14.0 & 11.9 & 12.9 & 10.4 \\
\hline Private sector & 81.5 & 82.0 & 77.9 & 81.3 & 84.2 & 82.5 & 89.1 \\
\hline Gross investment & 7.3 & 11.1 & 11.7 & 9.5 & 8.4 & 9.0 & 6.0 \\
\hline Central government & 4.1 & 7.3 & 7.2 & 4.7 & 3.5 & 4.8 & 2.1 \\
\hline Private sector & 3.3 & 3.8 & 4.5 & 4.8 & 4.9 & 4.2 & 3.9 \\
\hline
\end{tabular}

Sources: C.A.R. authorities; BEAC; and Fund staff estimates.

1/ Consumption figures reflect authorities' definition of public consumption, which includes public sector wages. 
Table 5. Central African Republic: Agricultural Production 1997/98-2003/04

(In thousands of tons)

$1997 / 98 \quad 1998 / 99 \quad 1999 / 2000 \quad 2000 / 01 \quad 2001 / 02 \quad 2002 / 03 \quad 2003 / 04$

Food crops

$\begin{array}{lrrrrrrr}\text { Cassava } & 578.7 & 607.6 & 509.0 & 500.0 & 561.7 & 563.2 & 564.3 \\ \text { Groundnuts } & 97.8 & 101.7 & 110.0 & 104.5 & 121.9 & 127.8 & 133.6 \\ \text { Millet and sorghum } & 38.8 & 41.0 & 45.8 & 41.8 & 50.3 & 52.9 & 53.1 \\ \text { Maize } & 82.6 & 88.0 & 95.0 & 89.3 & 107.0 & 113.0 & 119.0 \\ \text { Sesame } & 32.0 & 33.0 & 36.0 & 37.4 & 39.4 & 41.1 & 42.8 \\ \text { Rice } & 17.0 & 18.5 & 21.0 & 23.1 & 25.3 & 27.4 & 29.7 \\ \text { Gourds } & 18.0 & 19.2 & 23.0 & 21.8 & 25.5 & 26.8 & 27.9\end{array}$

Export crops

Unginned cotton $1 /$

Merchant coffee 2/

$\begin{array}{rr}46.0 & 38.6 \\ 6.4 & 11.5 \\ 0.2 & 0.3\end{array}$

21.3

24.5

32.8

12.5

1.5

Tobacco

0.3

12.1

5.6

5.7

2.0

3.5

0.2

0.1

0.1

0.1

0.1

Source: C.A.R. authorities.

1/ Cotton crop year ends October 31.

2/ One kilogram of merchant coffee is equivalent to 2 kilograms of coffee cerise . 
Table 6. Central African Republic: Cotton Price Structure, 1997/98-2002/03 1/

(In CFA francs per kilogram)

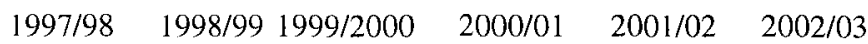

Est.

Total cost (unginned cotton)

Average producer price

Other 2/

Ratio of ginned to unginned cotton (in percent)

Equivalent cost (ginned cotton)

Ginning and sales services

Other general costs

Transport and related costs at seaports

Total costs, f.o.b. (ginned cotton)

Freight and insurance

Total costs, c.i.f. (ginned cotton)

Other costs and charges

Total costs

Average export price

Average sales price $3 /$

Export margin (loss -) 4/

Export volumes (thousands ton)

Total profit (loss -), (in billions of CFA francs)

\begin{tabular}{|c|c|c|c|c|c|}
\hline 186.6 & 198.7 & 176.7 & 192.7 & 202.0 & 181.0 \\
\hline 149.3 & 161.5 & 136.2 & 146.0 & 164.0 & 149.0 \\
\hline 37.3 & 37.2 & 40.5 & 46.7 & 38.0 & 32.0 \\
\hline 42.0 & 41.6 & 41.4 & 41.0 & 41.0 & 42.0 \\
\hline 443.9 & 477.7 & 427.3 & 469.5 & 492.7 & 431.0 \\
\hline 86.0 & 80.0 & 102.6 & 110.0 & 90.0 & 100.9 \\
\hline 96.5 & 93.8 & 227.4 & 215.7 & 150.0 & 197.7 \\
\hline 184.4 & 96.6 & 112.4 & 93.8 & 95.0 & 95.0 \\
\hline 810.8 & 748.1 & 869.7 & 889.0 & 827.7 & 824.6 \\
\hline 77.5 & 68.5 & 87.6 & 76.9 & 76.0 & 76.0 \\
\hline 888.3 & 816.6 & 957.3 & 965.9 & 903.7 & 900.6 \\
\hline 70.2 & 18.7 & 27.7 & 24.9 & 20.0 & 24.2 \\
\hline 958.5 & 835.3 & 985.0 & 990.8 & 923.7 & 924.8 \\
\hline 745.9 & 741.5 & 656.4 & 746.7 & 646.0 & 706.0 \\
\hline 940.0 & 757.7 & 667.5 & 746.5 & 646.0 & 706.0 \\
\hline-212.6 & -93.8 & -328.6 & -244.1 & -277.7 & -218.8 \\
\hline 17.4 & 13.5 & 11.2 & 9.9 & 12.3 & 0.9 \\
\hline-3.7 & -1.3 & -3.7 & -2.4 & -3.4 & -0.2 \\
\hline
\end{tabular}

Source: National cotton company (SOCOCA).

1/ Crop year ends October 31 .

2/ Transport and transaction costs.

3/ Including domestic sales.

4/ Average export price less total costs. 
Table 7. Central African Republic: Production and Exports of Forestry Products, 1997-2003

1997

1998

1999

2000

2001

2002

2003

Est.

(In thousands of cubic meters)

\begin{tabular}{lrrrrrrr} 
Production & 534.4 & 622.4 & 676.5 & 806.9 & 782.3 & 761.1 & 570.0 \\
Logs & 461.0 & 529.7 & 595.9 & 703.0 & 671.2 & 663.7 & 480.0 \\
Sawn wood & 72.0 & 91.3 & 78.9 & 102.4 & 109.3 & 95.4 & 88.1 \\
Plywood & 1.4 & 1.4 & 1.7 & 1.5 & 1.8 & 2.0 & 1.9 \\
& & & & & & & \\
Exports & 111.3 & 189.4 & 218.3 & 315.1 & 335.7 & 381.1 & 275.7 \\
Logs & 63.9 & 116.9 & 153.7 & 249.3 & 262.0 & 313.0 & 243.3 \\
Sawn wood & 47.3 & 72.2 & 64.0 & 65.6 & 72.8 & 67.5 & 32.1 \\
Plywood & 0.1 & 0.3 & 0.6 & 0.2 & 0.8 & 0.6 & 0.3 \\
& & & & & & & 57.3 \\
Domestic sales & 26.0 & 20.3 & 16.0 & 38.1 & 37.4 & 29.3 & 57.6 \\
Sawn wood & 24.7 & 19.1 & 14.9 & 36.8 & 36.5 & 27.9 & 56.0 \\
Plywood & 1.3 & 1.1 & 1.1 & 1.3 & 0.9 & 1.4 & 1.6 \\
& & & & & & & \\
& & & & & & & \\
Exports & 11.7 & 27.7 & 29.0 & 45.5 & 45.3 & 49.6 & 33.5 \\
Logs & 3.6 & 12.4 & 17.2 & 32.0 & 32.9 & 38.2 & 25.1 \\
Sawn Wood & 8.0 & 15.2 & 11.6 & 13.6 & 12.3 & 11.3 & 8.3 \\
Plywood & 0.0 & 0.1 & 0.1 & 0.0 & 0.1 & 0.1 & 0.0 \\
\hline
\end{tabular}

Source: Central African Republic, Ministry of Water and Forests. 
Table 8. Central African Republic: Manufacturing Output, 1997-2003

(In units indicated)

\begin{tabular}{|c|c|c|c|c|c|c|c|}
\hline & 1997 & 1998 & 1999 & 2000 & 2001 & 2002 & $\begin{array}{r}2003 \\
\text { Est. }\end{array}$ \\
\hline \multicolumn{8}{|l|}{ Food, beverages, and tobacco } \\
\hline Beer $1 /$ & 208.6 & 218.8 & 190.3 & 178.5 & 159.5 & 132.2 & 121.7 \\
\hline Soft drinks $1 /$ & 92.0 & 46.0 & 46.3 & 51.4 & 46.7 & 42.4 & 38.4 \\
\hline Syrups 1/ & 1.2 & 0.8 & $\ldots$ & $\ldots$ & $\ldots$ & $\ldots$ & \\
\hline Cigarettes $3 /$ & 0.0 & 0.0 & $\ldots$ & 14.8 & 16.1 & 16.6 & 16.1 \\
\hline Suger (powder) $2 /$ & 9.2 & 8.8 & 10.0 & 8.4 & 13.6 & 10.4 & $\ldots$ \\
\hline Soap 2/ & 0.8 & 1.1 & 1.3 & 1.2 & 1.7 & 1.6 & $\ldots$ \\
\hline Palm oil $2 /$ & 2.6 & 3.3 & $\ldots$ & $\ldots$ & 2.0 & 2.7 & $\ldots$ \\
\hline Groundnut oil 2/ & 2.3 & 2.7 & 2.0 & 1.9 & 1.8 & 1.3 & $\ldots$ \\
\hline \multicolumn{8}{|l|}{ Forestry } \\
\hline Sawn wood $4 /$ & 72.0 & 91.3 & 78.9 & 102.4 & 109.3 & 83.7 & 90.0 \\
\hline \multicolumn{8}{|l|}{ Chemical products } \\
\hline Oxygen $/ 4$ & 0.0 & 0.0 & $\ldots$ & $\ldots$ & 15.6 & 16.2 & $\ldots$ \\
\hline Paints $2 /$ & 0.0 & 0.0 & $\ldots$ & 0.2 & 0.2 & 0.4 & $\ldots$ \\
\hline \multicolumn{8}{|l|}{ Miscellaneous } \\
\hline Aluminum household items 2/ & 0.3 & 0.2 & $\ldots$ & 0.3 & 0.3 & 0.2 & 0.1 \\
\hline Aluminum sheets $2 /$ & 0.9 & 1.0 & $\ldots$ & 1.0 & 0.9 & 0.6 & 0.3 \\
\hline
\end{tabular}

Source: C.A.R. authorities.

1/ In thousands of hectoliters.

$2 /$ In thousands of tons.

3 / In millions of packets.

4/ In thousands of cubic meters. 
Table 9. Central African Republic: Production and Export of Diamonds and Gold, 1997-2003

(Diamonds in thousands of carats; gold in kilograms)

\begin{tabular}{|c|c|c|c|c|c|c|c|}
\hline & 1997 & 1998 & 1999 & 2000 & 2001 & 2002 & $\begin{array}{c}2003 \\
\text { Est. }\end{array}$ \\
\hline \multicolumn{8}{|l|}{ Production } \\
\hline Diamonds (rough) & 486.8 & 420.0 & 461.9 & 464.0 & 452.7 & 416.4 & 332.7 \\
\hline Gold & 35.1 & 23.8 & 41.1 & 15.1 & 33.9 & 15.9 & 2.2 \\
\hline \multicolumn{8}{|l|}{ Exports } \\
\hline Diamonds (rough) & 473.9 & 419.9 & 431.1 & 461.0 & 449.3 & 414.8 & 329.6 \\
\hline Gold & 28.7 & 18.3 & 32.7 & 15.0 & 28.7 & 10.9 & 2.2 \\
\hline
\end{tabular}

Source: C.A.R. authorities. 
Table 10. Central African Republic: Consumption of Oil Products, 1997-2003

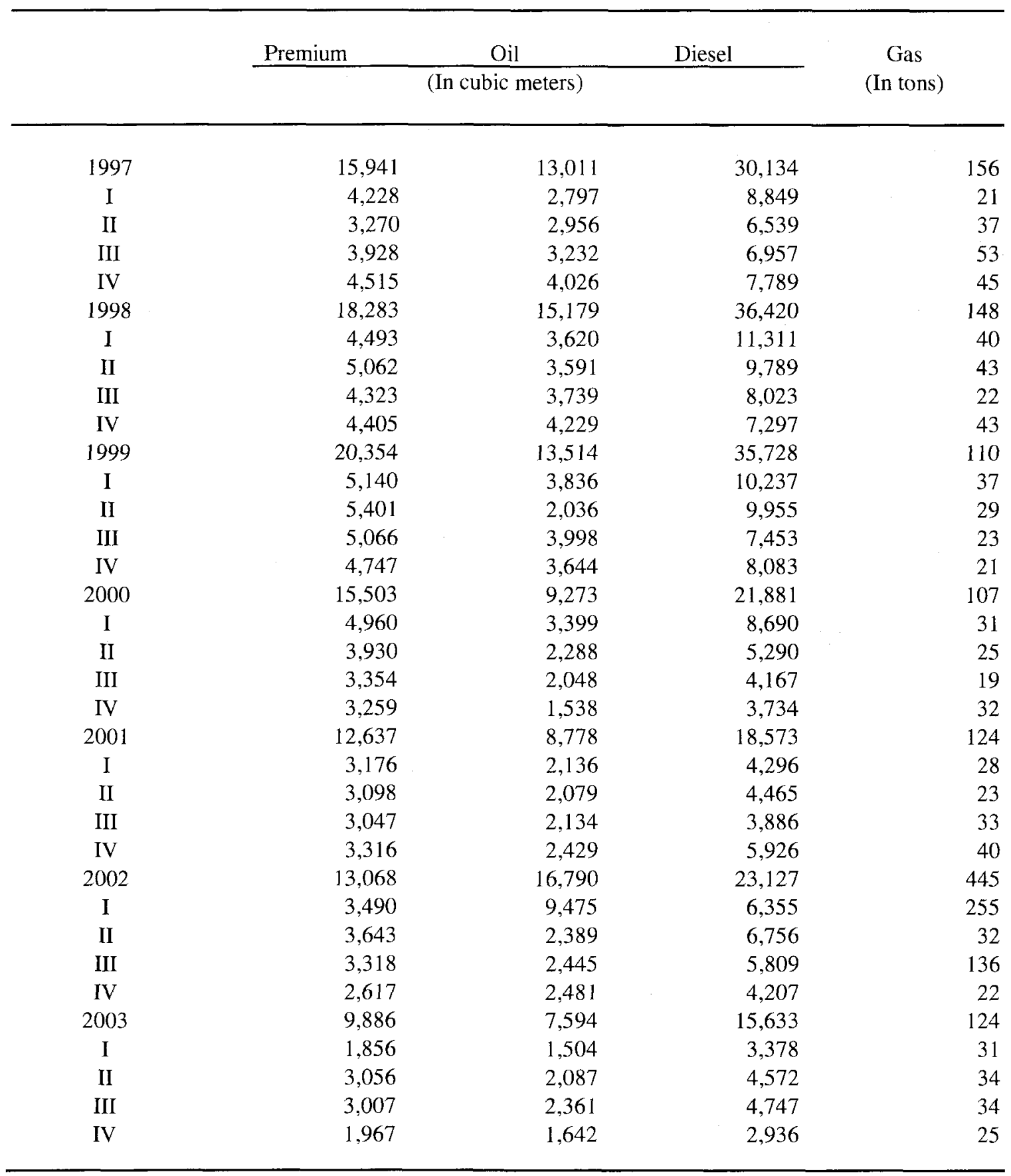

Source : C.A.R. authorities. 
(In CFA francs per liter)

\begin{tabular}{|c|c|c|c|c|c|c|c|c|c|c|c|c|c|c|}
\hline & \multicolumn{7}{|c|}{ Premium Gasoline } & \multicolumn{7}{|c|}{ Kerosene } \\
\hline & $\overline{1997}$ & 1998 & 1999 & 2000 & 2001 & 2002 & $\begin{array}{r}2003 \\
\text { Est. }\end{array}$ & 1997 & 1998 & 1999 & 2000 & 2001 & 2002 & $\begin{array}{r}2003 \\
\text { Est. } \\
\end{array}$ \\
\hline \multicolumn{15}{|l|}{ Average Platt's price over } \\
\hline Transport cost from Ango-Ango & 99.8 & 99.8 & 109.5 & $\ldots$ & 151.3 & 162.4 & 148.2 & 40.8 & 57.6 & 68.5 & $\ldots$ & 160.0 & 164.6 & 147.6 \\
\hline to Matadi & 10.2 & 10.2 & 15.2 & $\ldots$ & 34.9 & 43.3 & 43.3 & 6.5 & 10.5 & 20.0 & $\ldots$ & 16.1 & 43.3 & 43.3 \\
\hline C.i.f. price, Matadi & 109.9 & 109.9 & 124.7 & $\ldots$ & 186.2 & 205.7 & 191.5 & 47.3 & 68.1 & 88.5 & $\ldots$ & 176.1 & 207.9 & 190.9 \\
\hline Other transport costs & 60.4 & 60.4 & 60.1 & $\cdots$ & 124.8 & 43.8 & 54.7 & 84.4 & 86.6 & 86.3 & $\cdots$ & 141.5 & 46.1 & 58.5 \\
\hline Reference border prices & 170.4 & 170.4 & 184.8 & $\cdots$ & 311.0 & 249.5 & 246.2 & 131.7 & 154.7 & 174.8 & $\cdots$ & 317.6 & 254.0 & 249.4 \\
\hline Taxes and duties & 164.5 & 174.5 & 208.8 & & 208.9 & 136.4 & 134.4 & 61.4 & 87.4 & 84.0 & $\ldots$ & 74.4 & 2.1 & 2.3 \\
\hline Import duties & 0.0 & 10.0 & 10.0 & $\ldots$ & 10.0 & 0.0 & 0.0 & 0.0 & 10.0 & 10.0 & $\ldots$ & 0.0 & 0.0 & 0.0 \\
\hline Complementary tax & 60.0 & 60.0 & 60.0 & $\ldots$ & 60.0 & 0.0 & 0.0 & 0.0 & 0.0 & 0.0 & $\ldots$ & 0.0 & 0.0 & 0.0 \\
\hline Specific domestic tax & 71.3 & 49.3 & 83.5 & $\ldots$ & 83.5 & 0.0 & 0.0 & 64.0 & 77.4 & 74.0 & $\ldots$ & 74.0 & 0.0 & 0.0 \\
\hline Special tax & -22.0 & 0.0 & 0.0 & $\ldots$ & 0.0 & 0.0 & 0.0 & -2.6 & 0.0 & 0.0 & $\ldots$ & 0.0 & 0.0 & 0.0 \\
\hline Road use tax & 55.0 & 55.0 & 55.0 & $\ldots$ & 55.0 & 55.0 & 55.0 & 0.0 & 0.0 & 0.0 & $\ldots$ & 0.0 & 0.0 & 0.0 \\
\hline Miscellaneous charges & 0.0 & 0.0 & 0.0 & $\ldots$ & 0.0 & 0.0 & 0.0 & 0.0 & 0.0 & 0.0 & $\ldots$ & 0.0 & 0.0 & 0.0 \\
\hline Redevance informatique & 0.3 & 0.3 & 0.3 & $\ldots$ & 0.4 & 0.4 & 0.4 & 0.0 & 0.0 & 0.0 & $\cdots$ & 0.4 & 0.4 & 0.4 \\
\hline Custom duties & 0.0 & 0.0 & 0.0 & $\cdots$ & 0.0 & 16.0 & 14.5 & 0.0 & 0.0 & 0.0 & $\cdots$ & 0.0 & 0.0 & 0.0 \\
\hline Value-added Tax (VAT) 18 percent & 0.0 & 0.0 & 0.0 & $\ldots$ & 0.0 & 63.4 & 63.0 & 0.0 & 0.0 & 0.0 & $\ldots$ & 0.0 & 0.0 & 0.0 \\
\hline Community intergration tax & 0.0 & 0.0 & 0.0 & $\ldots$ & 0.0 & 1.6 & 1.5 & 0.0 & 0.0 & 0.0 & $\cdots$ & 0.0 & 1.7 & 1.9 \\
\hline Price structure administration & 0.0 & 0.0 & 0.0 & $\ldots$ & 1.0 & 1.0 & 1.0 & 0.0 & 0.0 & 0.0 & $\cdots$ & 1.0 & 1.0 & 1.0 \\
\hline Garanteed price in Bangui & 334.9 & 344.9 & 393.6 & $\ldots$ & 521.0 & 386.9 & 381.5 & 193.1 & 242.1 & 258.8 & $\ldots$ & 392.0 & 257.0 & 252.6 \\
\hline Storage financing cost & 5.0 & 5.0 & 5.0 & $\ldots$ & 5.0 & 5.0 & 0.0 & 5.0 & 5.0 & 5.0 & $\cdots$ & 5.0 & 5.0 & 0.0 \\
\hline Storage fees & 6.5 & 6.5 & 6.5 & $\ldots$ & 13.9 & 15.6 & 21.5 & 6.5 & 6.5 & 6.5 & $\cdots$ & 12.5 & 14.3 & 20.2 \\
\hline Retail margin & 40.0 & 40.0 & 26.3 & $\ldots$ & 50.0 & 50.0 & 50.0 & 25.0 & 35.0 & 11.0 & $\ldots$ & 50.0 & 50.0 & 50.0 \\
\hline Wholesale margin & 12.0 & 12.0 & 12.0 & $\ldots$ & 12.0 & 12.0 & 12.0 & 10.0 & 10.0 & 10.0 & $\ldots$ & 12.0 & 12.0 & 12.0 \\
\hline Equalization fees & 31.0 & 31.0 & 31.0 & $\cdots$ & 0.0 & 0.0 & 0.0 & 0.0 & 0.0 & 0.0 & $\cdots$ & 0.0 & 0.0 & 0.0 \\
\hline Financial fees & 6.0 & 6.0 & 6.0 & $\cdots$ & 6.2 & 11.4 & 11.4 & 0.0 & 6.0 & 6.0 & $\ldots$ & 6.4 & 11.9 & 11.7 \\
\hline Transportation costs & 2.6 & 2.6 & 2.6 & $\ldots$ & 4.0 & 4.0 & 4.0 & 0.0 & 2.6 & 2.6 & $\cdots$ & 4.0 & 4.0 & 4.0 \\
\hline Research and exploitation & 2.0 & 2.0 & 7.0 & $\cdots$ & 0.0 & 0.0 & 0.0 & 0.0 & 0.0 & 0.0 & $\ldots$ & 0.0 & 0.0 & 0.0 \\
\hline Average sales price & 440.0 & 450.0 & 490.0 & $\ldots$ & 612.1 & 484.9 & 480.4 & 220.1 & 250.0 & 275.0 & $\cdots$ & 482.9 & 354.2 & 350.6 \\
\hline TUPP & $\ldots$ & $\ldots$ & $\ldots$ & $\ldots$ & 37.9 & 165.1 & 169.7 & $\cdots$ & $\cdots$ & $\ldots$ & $\cdots$ & -132.9 & -4.2 & -0.6 \\
\hline Sales price at pump & $\ldots$ & $\ldots$ & $\ldots$ & $\ldots$ & 650.0 & 650.0 & 650.1 & $\ldots$ & $\cdots$ & $\cdots$ & $\cdots$ & 350.0 & 350.0 & 350.0 \\
\hline
\end{tabular}


Table 11. Central African Republic: Price Structurc of Petroleum Products, 1997-2003 (concluded)

(In CFA francs per liter)

\begin{tabular}{|c|c|c|c|c|c|c|c|c|c|c|c|c|c|c|}
\hline & \multicolumn{7}{|c|}{ Diesel fuel } & \multicolumn{7}{|c|}{ Heavy fuel } \\
\hline & 1997 & 1998 & 1999 & 2000 & 2001 & 2002 & $\begin{array}{r}2003 \\
\text { Est. }\end{array}$ & 1997 & 1998 & 1999 & 2000 & 2001 & 2002 & $\begin{array}{r}2003 \\
\text { Est. }\end{array}$ \\
\hline \multicolumn{15}{|l|}{ Average Platt's price over } \\
\hline Transport cost from Ango-Ango & 85.3 & 85.3 & 81.3 & $\ldots$ & 168.5 & 167.0 & 149.4 & 40.8 & 57.6 & 68.5 & $\ldots$ & 103.0 & 128.5 & 116.0 \\
\hline to Matadi & 15.9 & 15.9 & 18.3 & $\ldots$ & 38.7 & 43.3 & 43.3 & 6.5 & 10.5 & 20.0 & $\ldots$ & 29.5 & 69.5 & 69.5 \\
\hline C.i.f. price, Matadi & 101.2 & 101.2 & 99.6 & $\ldots$ & 207.2 & 210.3 & 192.7 & 47.2 & 68.1 & 88.5 & $\ldots$ & 132.5 & 198.0 & 185.5 \\
\hline Other transport costs & 64.4 & 64.4 & 64.2 & $\ldots$ & 123.6 & 49.1 & 61.5 & 84.4 & 86.6 & 86.3 & $\ldots$ & 141.3 & 53.9 & 53.9 \\
\hline Reference border prices & 165.6 & 165.6 & 163.8 & $\ldots$ & 330.8 & 259.4 & 254.2 & 131.6 & 154.7 & 174.8 & $\ldots$ & 273.8 & 251.9 & 239.4 \\
\hline Taxes and duties & 132.3 & 142.2 & 174.1 & $\ldots$ & 174.4 & 140.1 & 137.9 & 5.0 & 0.0 & 0.0 & $\ldots$ & 0.0 & 0.3 & 0.3 \\
\hline Import duties & 0.0 & 10.0 & 10.0 & $\ldots$ & 10.0 & 0.0 & 0.0 & 0.0 & 0.0 & 0.0 & $\ldots$ & 0.0 & 0.0 & 0.0 \\
\hline Complementary tax & 30.0 & 30.0 & 30.0 & $\ldots$ & 30.0 & 0.0 & 0.0 & 0.0 & 0.0 & 0.0 & $\ldots$ & 0.0 & 0.0 & 0.0 \\
\hline Specific domestic tax & 67.3 & 47.0 & 78.9 & $\ldots$ & 78.9 & 0.0 & 0.0 & 0.0 & 0.0 & 0.0 & $\ldots$ & 0.0 & 0.0 & 0.0 \\
\hline Special tax & -20.2 & 0.0 & 0.0 & $\ldots$ & 0.0 & 0.0 & 0.0 & 0.0 & 0.0 & 0.0 & $\ldots$ & 0.0 & 0.0 & 0.0 \\
\hline Road use ta: & 55.0 & 55.0 & 55.0 & $\ldots$ & 55.0 & 55.0 & 55.0 & 0.0 & 0.0 & 0.0 & $\ldots$ & 0.0 & 0.0 & 0.0 \\
\hline Miscellaneous charges & 0.0 & 0.0 & 0.0 & $\ldots$ & 0.0 & 0.0 & 0.0 & 5.0 & 0.0 & 0.0 & $\ldots$ & 0.0 & 0.0 & 0.0 \\
\hline Redevance informatique & 0.3 & 0.2 & 0.3 & $\ldots$ & 0.5 & 0.4 & 0.4 & 0.0 & 0.0 & 0.0 & $\ldots$ & 0.0 & 0.3 & 0.3 \\
\hline Custom duties & 0.0 & 0.0 & 0.0 & $\ldots$ & 0.0 & 16.9 & 15.4 & 0.0 & 0.0 & 0.0 & $\ldots$ & 0.0 & 0.0 & 0.0 \\
\hline Value-added Tax (VAT) 18 percent & 0.0 & 0.0 & 0.0 & $\ldots$ & 0.0 & 66.1 & 65.6 & 0.0 & 0.0 & 0.0 & $\ldots$ & 0.0 & 0.0 & 0.0 \\
\hline Community intergration tax & 0.0 & 0.0 & 0.0 & $\ldots$ & 0.0 & 1.7 & 1.5 & 0.0 & 0.0 & 0.0 & $\ldots$ & 0.0 & 0.0 & 0.0 \\
\hline Price structure administration & 0.0 & 0.0 & 0.0 & $\ldots$ & 1.0 & 1.0 & 1.0 & 0.0 & 0.0 & 0.0 & $\ldots$ & 1.0 & 1.0 & 1.0 \\
\hline Garanteed price in Bangui & 297.9 & 307.9 & 337.9 & $\ldots$ & 506.1 & 400.5 & 393.1 & 136.6 & 154.7 & 174.8 & $\ldots$ & 274.8 & 253.3 & 240.7 \\
\hline Storage financing cost & 5.0 & 5.0 & 5.0 & $\ldots$ & 5.0 & 5.0 & 0.0 & 0.0 & 0.0 & 0.0 & $\ldots$ & 5.0 & 5.1 & 0.0 \\
\hline Storage fees & 6.5 & 6.5 & 6.5 & $\ldots$ & 12.6 & 14.3 & 20.3 & 4.0 & 6.5 & 6.5 & $\ldots$ & 12.3 & 14.3 & 20.1 \\
\hline Retail margin & 20.0 & 20.0 & 20.0 & $\ldots$ & 50.0 & 50.0 & 50.0 & 79.4 & 80.2 & 85.1 & $\ldots$ & 50.0 & 50.0 & 50.0 \\
\hline Wholesale margin & 10.0 & 10.0 & 10.0 & $\ldots$ & 12.0 & 12.0 & 12.0 & 0.0 & 0.0 & 0.0 & $\ldots$ & 0.0 & 0.0 & 0.0 \\
\hline Equalization fees & 0.0 & 0.0 & 0.0 & $\ldots$ & 0.0 & 0.0 & 0.0 & 0.0 & 0.0 & 0.0 & $\ldots$ & 0.0 & 0.0 & 0.0 \\
\hline Financial fees & 6.0 & 6.0 & 6.0 & $\ldots$ & 6.8 & 12.1 & 12.0 & 0.0 & 6.0 & 6.0 & $\ldots$ & 5.6 & 11.8 & 10.9 \\
\hline Transportation costs & 2.6 & 0.0 & 0.0 & $\ldots$ & 4.0 & 4.0 & 4.0 & 0.0 & 2.6 & 2.6 & $\ldots$ & 4.0 & 4.0 & 4.0 \\
\hline Research and exploitation & 2.0 & 2.0 & 12.0 & $\ldots$ & 0.0 & 0.0 & 0.0 & 0.0 & 0.0 & 0.0 & $\ldots$ & 0.0 & 0.0 & 0.0 \\
\hline Average sales price & 350.0 & 357.4 & 397.4 & $\ldots$ & 597.5 & 498.9 & 492.4 & 220.0 & 250.0 & 275.0 & $\ldots$ & 352.7 & 339.4 & 326.7 \\
\hline TUPP & $\cdots$ & $\cdots$ & $\cdots$ & $\cdots$ & -22.5 & 76.1 & 82.6 & $\ldots$ & $\ldots$ & $\cdots$ & $\ldots$ & 37.3 & 50.6 & 63.3 \\
\hline Sales price at pump & $\ldots$ & $\ldots$ & $\ldots$ & $\ldots$ & 575.0 & 575.0 & 575.0 & & $\ldots$ & $\ldots$ & $\ldots$ & 390.0 & 390.0 & 390.0 \\
\hline
\end{tabular}

Source: National oil import company (PETROCA). 
Table 12. Central African Republic: Consumer Price Index, 1997-2003

(Period average; 1981=1,000)

\begin{tabular}{|c|c|c|c|c|c|c|}
\hline & Foodstuffs & Clothing & $\begin{array}{r}\text { Manufactured } \\
\text { Products }\end{array}$ & Energy & Services & $\begin{array}{r}\text { General } \\
\text { Index } 1 /\end{array}$ \\
\hline Weights & 705.0 & 85.0 & 76.0 & 73.0 & 61.0 & $1,000.0$ \\
\hline 1997 & 190.6 & 226.4 & 284.2 & 161.2 & 148.1 & 196.0 \\
\hline I & 187.2 & 222.2 & 285.6 & 158.2 & 148.8 & 193.2 \\
\hline II & 196.0 & 222.3 & 289.9 & 154.8 & 147.9 & 199.4 \\
\hline III & 188.0 & 231.4 & 282.0 & 166.7 & 151.8 & 195.1 \\
\hline IV & 191.2 & 229.5 & 279.2 & 165.0 & 143.8 & 196.3 \\
\hline 1998 & 186.6 & 228.4 & 283.4 & 173.6 & 141.5 & 193.8 \\
\hline I & 185.6 & 224.4 & 274.5 & 173.7 & 139.7 & 192.0 \\
\hline II & 190.1 & 220.7 & 279.0 & 171.3 & 138.6 & 194.9 \\
\hline III & 189.6 & 227.6 & 284.7 & 175.8 & 140.0 & 196.0 \\
\hline IV & 180.9 & 240.8 & 295.6 & 173.7 & 147.5 & 192.1 \\
\hline 1999 & 180.7 & 241.2 & 282.3 & 171.8 & 149.0 & 191.0 \\
\hline I & 179.2 & 243.2 & 292.0 & 173.8 & 151.0 & 191.1 \\
\hline II & 177.9 & 245.2 & 282.1 & 172.6 & 151.2 & 189.5 \\
\hline III & 185.7 & 245.2 & 278.2 & 168.0 & 151.9 & 194.4 \\
\hline IV & 179.9 & 231.1 & 277.0 & 172.6 & 142.0 & 188.8 \\
\hline 2000 & 187.9 & 234.7 & 292.5 & 182.3 & 153.3 & 197.3 \\
\hline I & 180.2 & 235.6 & 282.6 & 173.7 & 150.4 & 190.4 \\
\hline II & 187.3 & 231.8 & 292.1 & 182.3 & 148.4 & 196.3 \\
\hline III & 194.6 & 236.1 & 297.4 & 181.0 & 149.6 & 202.2 \\
\hline IV & 189.3 & 235.1 & 297.7 & 192.2 & 164.9 & 200.2 \\
\hline 2001 & 196.6 & 235.8 & 295.3 & 186.4 & 166.3 & 204.8 \\
\hline I & 191.4 & 233.7 & 293.8 & 186.7 & 163.3 & 200.7 \\
\hline II & 195.9 & 233.6 & 293.7 & 188.8 & 165.9 & 204.2 \\
\hline III & 200.0 & 236.1 & 295.8 & 185.4 & 167.2 & 207.3 \\
\hline IV & 199.0 & 239.9 & 297.9 & 184.7 & 168.6 & 207.1 \\
\hline 2002 & 200.5 & 246.1 & 302.2 & 190.0 & 171.7 & 209.6 \\
\hline I & 195.6 & 239.9 & 297.9 & 191.5 & 166.9 & 205.1 \\
\hline II & 193.0 & 250.5 & 303.4 & 192.2 & 176.4 & 205.2 \\
\hline III & 202.2 & 249.9 & 304.4 & 187.1 & 172.4 & 211.1 \\
\hline IV & 213.2 & 244.1 & 302.9 & 191.7 & 119.0 & 215.3 \\
\hline 2003 & 211.4 & 257.2 & 307.7 & 188.5 & 171.5 & 218.3 \\
\hline I & 220.8 & 235.2 & 307.2 & 186.9 & 170.7 & 223.1 \\
\hline II & 215.4 & 253.2 & 305.2 & 188.2 & 172.4 & 220.8 \\
\hline III & 204.7 & 262.7 & 310.3 & 188.6 & 171.1 & 214.4 \\
\hline IV & 203.3 & 279.4 & 308.1 & 190.2 & 171.6 & 214.8 \\
\hline
\end{tabular}

Source: C.A.R. authorities.

1/ Based on consumption basket for nationals living in Bangui. Averages are computed on the basis of weighted sectoral averages for the given time periods. 
Table 13. Central African Republic: Wholesale Price Index, 1997-2003

(Period average; $1981=1,000$ )

\begin{tabular}{|c|c|c|c|c|c|}
\hline & Foodstuffs & Clothing & $\begin{array}{r}\text { Manufactured } \\
\text { Products }\end{array}$ & Energy & $\begin{array}{l}\text { General } \\
\text { Index } 1 /\end{array}$ \\
\hline Weights & 424.0 & 83.0 & 262.0 & 231.0 & $1,000.0$ \\
\hline 1996 & 214.3 & 333.9 & 226.8 & 186.7 & 221.4 \\
\hline I & 204.9 & 321.1 & $\begin{array}{l}220.7 \\
224.4\end{array}$ & $\begin{array}{l}177.9 \\
1846\end{array}$ & $\begin{array}{l}212.4 \\
218.4\end{array}$ \\
\hline $\begin{array}{l}\text { II } \\
\text { III }\end{array}$ & $\begin{array}{l}209.7 \\
211.3\end{array}$ & $\begin{array}{l}331.6 \\
339.9\end{array}$ & $\begin{array}{l}224.4 \\
227.6\end{array}$ & $\begin{array}{l}184.6 \\
184.6\end{array}$ & 220.1 \\
\hline IV & 231.3 & 337.1 & 234.6 & 199.8 & 233.7 \\
\hline 1997 & 220.7 & 338.7 & 229.1 & 205.7 & 229.3 \\
\hline I & 225.0 & 336.2 & 231.8 & 205.3 & 231.5 \\
\hline II & 220.7 & 332.1 & 228.8 & 205.3 & 228.5 \\
\hline III & 218.7 & 346.9 & 227.1 & 205.3 & 228.4 \\
\hline IV & 218.3 & 339.7 & 228.7 & 206.7 & 228.4 \\
\hline 1998 & 219.3 & 347.1 & 227.6 & 206.7 & 229.2 \\
\hline I & 222.8 & 338.9 & 229.1 & 206.7 & 230.4 \\
\hline II & 216.7 & 350.3 & 224.4 & 206.7 & 227.5 \\
\hline III & 221.5 & 350.2 & 228.6 & 206.7 & 230.6 \\
\hline IV & 216.3 & 349.0 & 228.1 & 206.7 & 228.2 \\
\hline 1999 & 218.8 & 349.2 & 238.5 & 206.7 & 232.0 \\
\hline I & 216.9 & 344.7 & 232.7 & 206.7 & 229.3 \\
\hline II & 218.0 & 346.3 & 234.3 & 206.7 & 230.3 \\
\hline III & 220.0 & 350.8 & 240.8 & 206.7 & 233.2 \\
\hline IV & 220.4 & 354.8 & 246.2 & 206.7 & 235.2 \\
\hline 2000 & 224.6 & 365.0 & 249.1 & 248.6 & 248.2 \\
\hline I & 219.7 & 360.4 & 247.2 & 229.8 & 240.9 \\
\hline II & 222.9 & 362.9 & 247.6 & 229.7 & 242.6 \\
\hline III & 226.3 & 369.4 & 250.2 & 229.7 & 245.2 \\
\hline IV & 229.6 & 367.2 & 251.5 & 305.3 & 264.2 \\
\hline 2001 & 236.1 & 385.8 & 249.9 & 305.3 & 268.1 \\
\hline I & 229.9 & 379.8 & 249.6 & 305.3 & 264.9 \\
\hline II & 236.5 & 394.6 & 244.8 & 305.3 & 267.7 \\
\hline III & 237.5 & 364.3 & 251.1 & 305.3 & 267.2 \\
\hline IV & 240.5 & 404.3 & 254.0 & 305.3 & 272.6 \\
\hline 2002 & 298.6 & 466.3 & 265.4 & 307.3 & 268.1 \\
\hline I & 242.4 & 408.7 & 250.2 & 306.0 & 273.0 \\
\hline II & 392.3 & 460.2 & 261.3 & 307.5 & 344.0 \\
\hline III & 278.3 & 504.3 & 280.7 & 307.5 & 304.4 \\
\hline IV & 281.3 & 491.9 & 269.4 & 308.1 & 301.9 \\
\hline 2003 & 278.2 & 506.7 & 273.3 & 309.1 & 268.1 \\
\hline I & 286.4 & 492.0 & 273.3 & 309.1 & 305.3 \\
\hline II & 276.4 & 540.0 & 273.0 & 309.1 & 304.9 \\
\hline III & 274.0 & 524.6 & 276.7 & 309.1 & 303.6 \\
\hline IV & 276.0 & 470.3 & 270.3 & 309.1 & 298.3 \\
\hline
\end{tabular}

Source: C.A.R. authorities.

1/ Based on consumption basket for nationals living in Bangui. Averages are computed on the basis of weighted sectoral averages for the given time periods. 
Table 14. Central African Republic: Sectoral Composition of the Public Investment Program, 1997-2003 1/ (In billions of CFA francs)

\begin{tabular}{|c|c|c|c|c|c|c|c|}
\hline & 1997 & 1998 & 1999 & 2000 & 2001 & 2002 & $\begin{array}{r}2003 \\
\text { Est. }\end{array}$ \\
\hline Rural development & 5.7 & 9.2 & 7.5 & 9.1 & 7.3 & 3.1 & 0.5 \\
\hline Agriculture & 2.9 & 6.1 & 5.5 & 5.4 & 3.6 & 0.8 & 0.0 \\
\hline Livestock & 0.6 & 0.4 & 0.2 & 0.0 & 0.6 & 0.5 & 0.1 \\
\hline Forestry & 0.6 & 0.7 & 0.6 & 3.5 & 3.0 & 1.8 & 0.3 \\
\hline Fisheries & 0.0 & 0.0 & 0.0 & 0.0 & 0.0 & 0.0 & 0.0 \\
\hline Hunting and fishing & 1.6 & 2.0 & 1.2 & 0.2 & 0.1 & 0.0 & 0.0 \\
\hline Industry and mining & 0.8 & 0.6 & 0.0 & 0.2 & 0.4 & 0.0 & 0.0 \\
\hline Industry & 0.7 & 0.0 & 0.0 & 0.0 & 0.0 & 0.0 & 0.0 \\
\hline Mining & 0.1 & 0.6 & 0.0 & 0.2 & 0.4 & 0.0 & 0.0 \\
\hline Economic infrastructure & 19.1 & 34.0 & 29.8 & 39.8 & 29.1 & 18.4 & 3.3 \\
\hline Energy & 0.1 & 0.0 & 0.0 & 0.9 & 0.4 & 0.0 & 0.0 \\
\hline Water & 1.5 & 1.2 & 1.6 & 6.2 & 3.1 & 0.5 & 0.1 \\
\hline Habitat; urban development & 3.5 & 1.0 & 2.1 & 6.4 & 3.1 & 9.2 & 3.0 \\
\hline Infrastructure & 14 & 30.5 & 26.1 & 26.3 & 22.4 & 8.5 & 0.1 \\
\hline Land transport & 13.8 & 30.5 & 25.5 & 26.3 & 22.0 & 8.5 & 0.1 \\
\hline River transport & 0.0 & 0.0 & 0.6 & 0.0 & 0.4 & 0.0 & 0.0 \\
\hline Air transport & 0.2 & 0.0 & 0.0 & 0.0 & 0.0 & 0.0 & 0.0 \\
\hline Post and telecommunications & 0.0 & 0.0 & 0.0 & 0.0 & 0.0 & 0.0 & 0.0 \\
\hline Radio, television, and press & 0.0 & 0.8 & 0.0 & 0.0 & 0.1 & 0.0 & 0.2 \\
\hline Commerce, insurance, and tourism & 0.0 & 0.5 & 0.0 & .. & $\ldots$ & 0.1 & 0.0 \\
\hline Social infrastructure & 5.1 & 7.7 & 15.8 & 11.8 & 19.5 & 11.4 & 5.3 \\
\hline Health & 2.1 & 2.6 & 4.4 & 6.0 & 8.0 & 4.2 & 1.8 \\
\hline Education & 0.4 & 0.4 & 1.3 & 0.8 & 3.5 & 0.6 & 0.2 \\
\hline Social affairs & 1.0 & 1.1 & 3.2 & 2.0 & 2.0 & 2.2 & 0.3 \\
\hline Administration & 1.6 & 3.6 & 6.9 & 3.0 & 6.0 & 4.4 & 2.9 \\
\hline Unallocated & 0.0 & 7.8 & 8.5 & 1.8 & 0.0 & 13.1 & 10.5 \\
\hline Total & 30.7 & 59.3 & 61.6 & 62.8 & 56.4 & 32.9 & 9.0 \\
\hline \multicolumn{8}{|l|}{ Sources of financing } \\
\hline Domestic 2/ & 4.4 & 10.6 & 16.8 & 10.3 & 9.7 & 13.5 & 10.5 \\
\hline External & 26.3 & 48.7 & 44.8 & 52.5 & 46.7 & 32.5 & 9.0 \\
\hline Grants & 23.6 & 48.1 & 43.4 & 49.3 & 39.5 & 26.5 & 5.0 \\
\hline Loans & 2.7 & 0.5 & 1.4 & 3.2 & 7.2 & 6.0 & 4.0 \\
\hline Total & 30.7 & 59.3 & 61.6 & 62.8 & 56.4 & 46.0 & 19.5 \\
\hline
\end{tabular}

Source: C.A.R. authorities.

1/ Results for some years do not correspond to those in Table 15 owing to differences concerning the amount of grants effectively disbursed at year end.

$2 /$ Includes counterparts of customs duties on project-related imports. 
Table 15. Central African Republic: Government Operations, 1997-2003

\begin{tabular}{|c|c|c|c|c|c|c|c|}
\hline & 1997 & 1998 & 1999 & 2000 & 2001 & 2002 & $\begin{array}{r}2003 \\
\text { Est. }\end{array}$ \\
\hline & \multicolumn{7}{|c|}{ (In billions of CFA francs) } \\
\hline Revenue & 45.0 & 56.3 & 59.7 & 60.5 & 63.2 & 78.4 & 53.7 \\
\hline Tax revenue & 42.4 & 50.3 & 53.5 & 53.4 & 51.8 & 61.4 & 45.3 \\
\hline Nontax revenue & 2.6 & 6.1 & 6.2 & 7.1 & 11.4 & 17.0 & 8.4 \\
\hline Expenditure & -81.9 & -109.5 & -116.1 & -105.7 & -93.6 & -114.6 & -85.5 \\
\hline Current primary expenditure & -43.3 & -41.9 & -45.4 & -51.6 & -51.0 & -57.3 & -58.1 \\
\hline Interest due & -7.8 & -8.3 & -9.1 & -11.5 & -9.8 & -11.3 & -7.9 \\
\hline Capital expenditure & -30.7 & -59.3 & -61.6 & -42.6 & -32.8 & -46.0 & -19.5 \\
\hline Of which : domestically financed & -4.4 & -10.6 & -16.8 & -10.3 & -9.7 & -13.5 & -10.5 \\
\hline \multicolumn{8}{|l|}{ Overall balance, commitment basis } \\
\hline Excluding grants & -36.8 & -53.1 & -56.3 & -45.2 & -30.5 & -36.2 & -31.8 \\
\hline Of which: narrow primary balance $\mathrm{I}$ & -2.7 & 3.8 & -2.5 & -1.4 & 2.5 & 7.6 & -14.9 \\
\hline Including grants & -8.9 & 0.0 & -3.0 & -12.4 & -6.2 & -8.6 & -21.8 \\
\hline Change in arrears (reduction -) & 20.6 & -70.1 & -3.0 & -2.9 & -7.3 & 21.3 & 28.4 \\
\hline Domestic & 4.3 & -2.8 & -3.5 & -8.7 & -15.1 & -4.7 & 4.1 \\
\hline External & 16.2 & -67.3 & 0.5 & 5.9 & 7.8 & 26.1 & 24.3 \\
\hline Overall balance, cash basis & -16.3 & -123.2 & -59.3 & -48.1 & -37.7 & -14.8 & -3.5 \\
\hline Extemal financing, net & 18.7 & 119.7 & 56.0 & 39.3 & 26.5 & 14.5 & -1.3 \\
\hline Projects & 26.3 & 48.7 & 44.8 & 32.3 & 23.1 & 32.5 & 9.0 \\
\hline Grants & 23.6 & 48.1 & 43.4 & 31.6 & 21.8 & 26.5 & 6.0 \\
\hline Loans & 2.7 & 0.5 & 1.4 & 0.7 & 1.3 & 6.0 & 3.0 \\
\hline Program & 4.4 & 5.0 & 9.9 & 9.9 & 12.2 & 2.3 & 9.1 \\
\hline Grants & 4.4 & 5.0 & 9.9 & 1.2 & 2.5 & 1.0 & 4.1 \\
\hline Loans & 0.0 & 0.0 & 0.0 & 8.7 & 9.7 & 1.3 & 5.0 \\
\hline Amortization due & -12.0 & -10.4 & -13.7 & -15.9 & -15.2 & -20.4 & -19.4 \\
\hline Extcrnal debt relief & 0.0 & 76.4 & 15.1 & 12.9 & 6.4 & 0.0 & 0.0 \\
\hline Domestic financing, net & -2.4 & 3.5 & 3.3 & 8.8 & 11.2 & 0.4 & 4.8 \\
\hline Banking system & -1.4 & 1.8 & 4.3 & 6.9 & 9.1 & 1.0 & 5.2 \\
\hline Bank of Central African States & -2.9 & 0.2 & 4.5 & 1.4 & 8.9 & 2.1 & 3.1 \\
\hline Counterpart to IMF resources & -4.4 & -1.1 & 3.9 & -0.6 & 7.3 & 0.0 & 0.0 \\
\hline Other & 1.5 & 1.3 & 0.6 & 2.0 & 1.7 & 2.1 & 3.1 \\
\hline Commercial banks & 1.5 & 1.6 & -0.1 & 5.4 & 0.2 & -1.1 & 2.1 \\
\hline Nonbank & -1.0 & 1.7 & -1.1 & 1.9 & 2.1 & -0.6 & -0.4 \\
\hline Memorandum items: & \multicolumn{7}{|c|}{ (In percent of GDP) } \\
\hline Revenue & 8.0 & 9.3 & 9.4 & 8.9 & 8.9 & 10.8 & 7.7 \\
\hline Expenditure & -14.5 & -18.1 & -18.2 & -15.5 & -13.2 & -15.8 & -12.3 \\
\hline Of which: military expenditure & & & & & & & \\
\hline Current primary expenditure & -7.7 & -6.9 & -7.1 & -7.6 & -7.2 & -7.9 & -8.3 \\
\hline Interest due & -1.4 & -1.4 & -1.4 & -1.7 & -1.4 & -1.6 & -1.1 \\
\hline Capital expenditure & -5.4 & -9.8 & -9.6 & -6.2 & -4.6 & -6.3 & -2.8 \\
\hline \multicolumn{8}{|l|}{ Balance, commitments basis (deficit -) } \\
\hline Excluding grants & -6.5 & -8.8 & -8.8 & -6.6 & -4.3 & -5.0 & -4.6 \\
\hline Including grants & -1.6 & 0.0 & -0.5 & -1.8 & -0.9 & -1.2 & -3.1 \\
\hline Narrow primary budget balance $1 /$ & -0.5 & 0.6 & -0.4 & -0.2 & 0.3 & 1.0 & -2.1 \\
\hline $\begin{array}{l}\text { GDP at current market prices } \\
\text { (in billions of CFA francs) }\end{array}$ & 566.0 & 606.4 & 638.7 & 683.1 & 709.2 & 726.2 & 696.4 \\
\hline
\end{tabular}

Sources : C.A.R. authorities; and Fund staff estimates.

1/ Excludes interest payments and externally financed investment. 
Table 16. Central African Republic: Central Government Revenue, 1997-2003

$\begin{array}{lllllll}1997 & 1998 & 1999 & 2000 & 2001 & 2002 & 2003\end{array}$

\begin{tabular}{|c|c|c|c|c|c|c|c|}
\hline \multirow[b]{2}{*}{ Total revenue } & \multicolumn{7}{|c|}{ (In billions of CFA francs) } \\
\hline & 45.0 & 56.3 & 59.7 & 60.5 & 63.2 & 78.4 & 53.7 \\
\hline Tax revenue & 42.4 & 50.3 & 53.5 & 53.4 & 51.8 & 61.4 & 45.3 \\
\hline Taxes on income and profits & 11.7 & 13.9 & 14.7 & 12.6 & 15.2 & 17.2 & 14.0 \\
\hline Companies & 1.8 & 2.4 & 3.4 & 2.3 & 0.0 & 0.0 & 0.0 \\
\hline Individuals & 5.3 & 3.5 & 6.5 & 5.8 & 0.0 & 0.0 & 0.0 \\
\hline Other & 4.7 & 8.0 & 4.7 & 4.5 & 15.2 & 17.2 & 14.0 \\
\hline Taxes on goods and services & 21.5 & 27.2 & 29.0 & 30.3 & 24.8 & 33.3 & 20.5 \\
\hline Tunover tax & 4.3 & 4.7 & 4.5 & 7.5 & 0.0 & 0.0 & 0.0 \\
\hline Excise tax & 1.1 & 1.1 & 0.7 & 1.5 & 0.0 & 0.0 & 0.0 \\
\hline Other & 16.1 & 21.4 & 23.8 & 21.4 & 24.8 & 33.3 & 20.5 \\
\hline Taxes on international trade & 9.1 & 9.2 & 9.9 & 10.5 & 11.8 & 10.9 & 10.7 \\
\hline Import taxes and duties & 5.4 & 5.5 & 5.4 & 6.6 & 7.0 & 7.6 & 7.7 \\
\hline Customs duties & 15.4 & 17.2 & 15.4 & 6.6 & 0.0 & 0.0 & 0.0 \\
\hline Other taxes and duties & -10.0 & -11.7 & -10.0 & 0.0 & 7.0 & 7.6 & 7.7 \\
\hline Export taxes and duties & 3.7 & 3.7 & 4.5 & 3.9 & 4.8 & 3.2 & 3.1 \\
\hline Nontax revenue & 2.6 & 6.1 & 6.2 & 7.1 & 11.4 & 17.0 & 8.4 \\
\hline Dividends & 0.2 & 0.1 & 0.0 & 0.0 & 0.0 & 0.0 & 0.0 \\
\hline \multirow[t]{2}{*}{ Other } & 2.4 & 6.0 & 6.2 & 7.1 & 11.4 & 17.0 & 8.4 \\
\hline & \multicolumn{7}{|c|}{ (In percent of total revenue) } \\
\hline Tax revenue & 94.3 & 89.2 & 89.6 & 88.2 & 82.0 & 78.3 & 84.3 \\
\hline Taxes on income and profits & 26.1 & 24.6 & 24.5 & 20.8 & 24.0 & 22.0 & 26.2 \\
\hline Taxes on goods and services & 47.9 & 48.2 & 48.5 & 50.1 & 39.3 & 42.5 & 38.2 \\
\hline Taxes on international trade & 20.3 & 16.4 & 16.5 & 17.3 & 18.7 & 13.9 & 20.0 \\
\hline Nontax revenue & 5.7 & 10.8 & 10.4 & 11.8 & 18.0 & 21.7 & 15.7 \\
\hline & \multicolumn{7}{|c|}{ (In percent of GDP) } \\
\hline Total revenue & 8.0 & 9.3 & 9.4 & 8.9 & 8.9 & 10.8 & 7.7 \\
\hline Tax revenue & 7.5 & 8.3 & 8.4 & 7.8 & 7.3 & 8.5 & 6.5 \\
\hline Taxes on income and profits & 2.1 & 2.3 & 2.3 & 1.8 & 2.1 & 2.4 & 2.0 \\
\hline Taxes on goods and services & 3.8 & 4.5 & 4.5 & 4.4 & 3.5 & 4.6 & 2.9 \\
\hline Taxes on international trade & 1.6 & 1.5 & 1.5 & 1.5 & 1.7 & 1.5 & 1.5 \\
\hline Nontax revenue & 0.5 & 1.0 & 1.0 & 1.0 & 1.6 & 2.3 & 1.2 \\
\hline & \multicolumn{7}{|c|}{ (In percent of imports, c.i.f.) } \\
\hline Import taxes and duties & 4.9 & 4.7 & 4.9 & 5.7 & 6.4 & 7.0 & 9.1 \\
\hline & \multicolumn{7}{|c|}{ (In percent of exports, f.o.b.) } \\
\hline Export taxes and duties & 1.9 & 3.3 & 5.0 & 6.8 & 4.6 & 3.2 & 4.5 \\
\hline & \multicolumn{7}{|c|}{ (Elasticity relative to nominal GDP) } \\
\hline Total revenue & 3.7 & 3.5 & 1.1 & 0.2 & 1.1 & 10.1 & 7.7 \\
\hline Tax revenue & 3.0 & 2.6 & 1.2 & 0.0 & -0.8 & 7.7 & 6.4 \\
\hline Taxes on income and profits & 4.7 & 2.5 & 1.1 & -2.0 & 5.3 & 5.7 & 4.5 \\
\hline Taxes on goods and services & 8.4 & 3.7 & 1.3 & 0.7 & -4.7 & 14.3 & 9.4 \\
\hline Taxes on international trade & $-3,1$ & 0.1 & 1.3 & 0.9 & 3.3 & -3.3 & 0.3 \\
\hline Nontax revenue & 91.9 & 19.0 & 0.3 & 2.2 & 15.5 & 20.9 & 12.3 \\
\hline \multicolumn{8}{|l|}{ Memorandum item: } \\
\hline Nominal GDP growth & 9.6 & 7.1 & 5.3 & 7.0 & 3.8 & 2.4 & -4.1 \\
\hline
\end{tabular}

Sources : C.A.R. authorities; and Fund staff estimates. 
Table 17. Central African Republic: Central Government Expenditure, 1997-2003

\begin{tabular}{rrrrrrrrrr}
\hline & 1997 & 1998 & 1999 & 2000 & 2001 & 2002 & 2003 \\
& & & & & & &
\end{tabular}

(In billions of CFA francs)

\begin{tabular}{|c|c|c|c|c|c|c|c|}
\hline Total expenditure & 81.9 & 109.5 & 116.1 & 105.7 & 93.6 & 114.6 & 85.5 \\
\hline Current expenditure & 51.2 & 50.2 & 54.5 & 63.1 & 60.9 & 68.6 & 66.0 \\
\hline Current primary expenditure & 43.3 & 41.9 & 45.4 & 51.6 & 51.0 & 57.3 & 58.1 \\
\hline Wages and salaries & 26.6 & 26.5 & 26.4 & 28.9 & 29.2 & 33.1 & 34.5 \\
\hline Transfers and subsidies & 4.8 & 5.1 & 7.3 & 8.2 & 7.2 & 7.1 & 7.3 \\
\hline Goods and services & 11.9 & 10.3 & 11.7 & 14.5 & 14.6 & 17.1 & 16.3 \\
\hline Interest due & 7.8 & 8.3 & 9.1 & 11.5 & 9.8 & 11.3 & 7.9 \\
\hline External & 6.1 & 6.9 & 8.1 & 10.2 & 8.5 & 7.3 & 5.0 \\
\hline Domestic & 1.7 & 1.4 & 1.0 & 1.3 & 1.3 & 3.9 & 2.9 \\
\hline Public investment program & 30.7 & 59.3 & 61.6 & 42.6 & 32.8 & 46.0 & 19.5 \\
\hline Domestically financed & 4.4 & 10.6 & 16.8 & 10.3 & 9.7 & 13.5 & 10.5 \\
\hline Externally financed & 26.3 & 48.7 & 44.8 & 32.3 & 23.1 & 32.5 & 9.0 \\
\hline & \multicolumn{7}{|c|}{ (In percent of total revenue) } \\
\hline Total expenditure & 181.9 & 194.3 & 194.3 & 174.6 & 148.2 & 146.1 & 159.3 \\
\hline Current expenditure & 113.7 & 89.1 & 91.2 & 104.2 & 96.4 & 87.5 & 123.0 \\
\hline Current primary expenditure & 96.3 & 74.4 & 76.0 & 85.2 & 80.8 & 73.1 & 108.3 \\
\hline Wages and salaries & 59.2 & 46.9 & 44.2 & 47.7 & 46.3 & 42.2 & 64.2 \\
\hline Transfers and subsidies & 10.6 & 9.1 & 12.2 & 13.5 & 11.4 & 9.1 & 13.7 \\
\hline Goods and services & 26.5 & 18.4 & 19.6 & 23.9 & 23.1 & 21.8 & 30.4 \\
\hline Interest due & 17.4 & 14.7 & 15.2 & 19.0 & 15.6 & 14.4 & 14.8 \\
\hline Public investment program & 68.2 & 105.2 & 103.1 & 70.4 & 51.9 & 58.7 & 36.3 \\
\hline \multirow[t]{2}{*}{ Of which: domestically financed } & 9.8 & 18.9 & 28.1 & 17.0 & 15.3 & 17.2 & 19.5 \\
\hline & \multicolumn{7}{|c|}{ (In percent of GDP) } \\
\hline Total expenditure & 14.5 & 18.1 & 18.2 & 15.5 & 13.2 & 15.8 & 12.3 \\
\hline Current expenditure & 9.0 & 8.3 & 8.5 & 9.2 & 8.6 & 9.4 & 9.5 \\
\hline Current primary expenditure & 7.7 & 6.9 & 7.1 & 7.6 & 7.2 & 7.9 & 8.3 \\
\hline Wages and salaries & 4.7 & 4.4 & 4.1 & 4.2 & 4.1 & 4.6 & 4.9 \\
\hline Transfers and subsidies & 0.8 & 0.8 & 1.1 & 1.2 & 1.0 & 1.0 & 1.1 \\
\hline Goods and services & 2.1 & 1.7 & 1.8 & 2.1 & 2.1 & 2.4 & 2.3 \\
\hline Interest due & 1.4 & 1.4 & 1.4 & 1.7 & 1.4 & 1.6 & 1.1 \\
\hline Public investment program & 5.4 & 9.8 & 9.6 & 6.2 & 4.6 & 6.3 & 2.8 \\
\hline \multirow[t]{2}{*}{ Of which: domestically financed } & 0.8 & 1.8 & 2.6 & 1.5 & 1.4 & 1.9 & 1.5 \\
\hline & \multicolumn{7}{|c|}{ (Annual percentage change) } \\
\hline Total expenditure & 35.2 & 33.8 & 6.0 & -8.9 & -11.5 & 22.4 & -25.4 \\
\hline Current expenditure & 8.1 & -1.9 & 8.5 & 15.9 & -3.6 & 12.7 & -3.8 \\
\hline Current primary expenditure & 17.3 & -3.3 & 8.4 & 13.7 & -1.1 & 12.3 & 1.4 \\
\hline Wages and salaries & 5.4 & -0.7 & -0.2 & 9.5 & 1.1 & 13.2 & 4.2 \\
\hline Transfers and subsidies & -5.5 & 7.1 & 43.1 & 12.3 & -12.2 & -1.1 & 2.9 \\
\hline Goods and services & 79.7 & -13.2 & 13.1 & 23.9 & 0.8 & 17.2 & -4.7 \\
\hline Interest due & -24.8 & 6.2 & 9.2 & 26.9 & -14.7 & 14.8 & -29.8 \\
\hline Public investment program & 132.4 & 93.1 & 3.9 & -30.8 & -23.1 & 40.5 & -57.7 \\
\hline Of which: domestically financed & 127.0 & 141.5 & 58.0 & -38.7 & -6.3 & 39.8 & -22.4 \\
\hline
\end{tabular}

Sources : C.A.R. authorities; and Fund staff estimates. 
Table 18. Central African Republic: Interest Rate Structure, March 1997-December 2003

(In percent per annum)

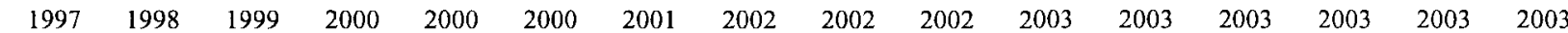

Mar-23 Jul-12 Dec-6 Jan-14 May-25 Sep-13 Sep-6 Jan-7 Apr-11 Dec-18 Apr-02 May-09 Jun-18 Jul-28 Oct-28 Dec-01

Central bank

Lending operations

Penalty rate on advances

Auction rate (TIAO) 1 I

Repurchase rate (TIPP) 2

Penalty rate on lending to banks

\begin{tabular}{|c|c|c|c|c|c|c|c|c|c|c|c|c|c|c|c|}
\hline 7.50 & 7.00 & 7.60 & 7.30 & 7.00 & 7.00 & 6.50 & 6.50 & 6.35 & 6.30 & 6.30 & 6.30 & 6.30 & 6.30 & 6.30 & 6.00 \\
\hline 10.25 & 10.50 & 10.50 & 10.50 & 10.50 & 10.50 & 10.50 & 10.50 & 10.50 & 10.50 & 10.50 & 10.50 & 10.50 & 10.50 & 10.50 & 10.00 \\
\hline 7.50 & 7.00 & 7.60 & 7.30 & 7.00 & 7.00 & 6.50 & 6.50 & 6.35 & 6.30 & 6.30 & 6.30 & 6.30 & 6.30 & 6.30 & 6.0 \\
\hline 9.50 & 9.00 & 9.60 & 9.30 & 9.00 & 9.00 & 8.50 & 8.50 & 8.35 & 8.30 & 8.30 & 8.30 & 8.30 & 8.30 & 8.30 & \\
\hline 15.00 & 15.00 & 15.00 & 15.00 & 15.00 & 15.00 & 15.00 & 15.00 & 15.00 & 15.00 & 15.00 & 15.00 & 15.00 & 15.00 & 15.00 & 15. \\
\hline 3.00 & 2.75 & 3.15 & 3.25 & 3.30 & 3.60 & 3.60 & 3.40 & 3.00 & 2.70 & 2.60 & 2.50 & 2.20 & 2.05 & 1.95 & \\
\hline 3.00 & 2.75 & 3.15 & 3.25 & 3.30 & 3.60 & 3.60 & 3.40 & 3.00 & 2.70 & 2.60 & 2.50 & 2.20 & 2.05 & 1.95 & \\
\hline 3.06 & 2.81 & 3.21 & 3.31 & 3.36 & 3.66 & 3.66 & 3.46 & 3.00 & 2.76 & 2.66 & 2.26 & 2.11 & 2.01 & 2.01 & \\
\hline 3.13 & 2.88 & 3.28 & 3.38 & 3.43 & 3.73 & 3.73 & 3.53 & 3.00 & 2.83 & 2.73 & 3.63 & 2.33 & 2.18 & 2.08 & \\
\hline
\end{tabular}

Rate on special deposits by national treasuries

BEAC certificates (TISP) 3 /

7-day maturity

28-day maturity

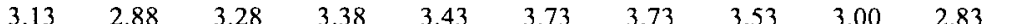

84-day maturity

Commercial banks

Maximum lending rate

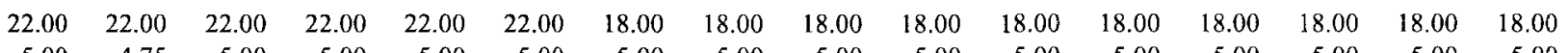

Minimum deposit rate

$5.00 \quad 4.75$

$5.00 \quad 5.00$

Source: Bank of Central African States (BEAC)

$1 /$ The auction rate, set by the BEAC, is derived from the money market auctions and constitutes the reference rate.

$2 /$ The repurchase rate is the basic rate and is set at 1.5 to 2 percentage points above the auction rate

$3 /$ Introduced in February 1996; the rates on certificates with maturities of 28 and 84 days are equal to the rate on the seven-day maturity plus a fixed margin of $1 / 16$ and of $1 / 8$ percentage points, res 
Table 19. Central African Republic: Monetary Survey, 1997-2003

\begin{tabular}{|c|c|c|c|c|c|c|c|}
\hline & 1997 & 1998 & 1999 & 2000 & 2001 & 2002 & $\begin{array}{r}2003 \\
\text { Est. }\end{array}$ \\
\hline & \multicolumn{7}{|c|}{ (In billions of CFA francs) } \\
\hline Net foreign assets & 96.6 & 72.5 & 73.9 & 79.5 & 63.7 & 55.7 & 48.7 \\
\hline Central Bank & 97.5 & 73.3 & 75.4 & 80.5 & 66.3 & 58.1 & 52.0 \\
\hline Operations account & 106.8 & 81.8 & 88.8 & 93.4 & 87.6 & 76.9 & 68.7 \\
\hline Use of IMF credit & -11.1 & -9.8 & -15.3 & -15.1 & -22.9 & -20.9 & -19.7 \\
\hline Other & 1.8 & 1.4 & 1.9 & 2.2 & 1.6 & 2.1 & 3.0 \\
\hline Commercial banks & -0.8 & -0.9 & -1.4 & -1.0 & -2.7 & -2.4 & -3.3 \\
\hline Net domestic assets & 19.7 & 25.1 & 31.3 & 31.4 & 46.0 & 49.2 & 51.2 \\
\hline Domestic credit & 59.4 & 66.1 & 75.1 & 78.4 & 97.1 & 99.6 & 103.2 \\
\hline Net credit to the government & 28.8 & 30.1 & 34.8 & 39.5 & 54.6 & 50.2 & 55.2 \\
\hline Central government & 30.9 & 32.5 & 38.4 & 45.7 & 55.3 & 54.3 & 58.4 \\
\hline Other public agencies & -2.1 & -2.4 & -3.6 & -6.2 & -0.7 & -4.1 & -3.2 \\
\hline Credit to the economy & 30.5 & 35.9 & 40.3 & 38.9 & 42.5 & 49.4 & 48.0 \\
\hline Public enterprises & 6.4 & 8.0 & 14.2 & 8.0 & 8.0 & 8.1 & 8.9 \\
\hline Private sector & 24.2 & 28.0 & 26.1 & 30.9 & 34.5 & 41.3 & 39.1 \\
\hline Other items (net) & -39.7 & -41.0 & -43.8 & -47.0 & -51.1 & -50.3 & -52.0 \\
\hline Broad money & 116.3 & 97.5 & 105.3 & 110.9 & 109.7 & 104.9 & 99.9 \\
\hline Currency outside banks & 93.0 & 75.2 & 81.1 & 88.6 & 82.6 & 77.4 & 71.4 \\
\hline Deposits & 23.4 & 22.3 & 24.2 & 22.3 & 27.1 & 27.5 & 28.5 \\
\hline Demand deposits & 14.2 & 12.3 & 14.6 & 13.2 & 16.6 & 17.3 & 17.6 \\
\hline Time deposits & 9.1 & 10.0 & 9.6 & 9.1 & 10.5 & 10.2 & 10.9 \\
\hline \multicolumn{8}{|l|}{ Memorandum item: } \\
\hline \multirow[t]{2}{*}{ Velocity of broad money $1 /$} & 4.7 & 5.6 & 6.3 & 6.2 & 6.3 & 6.6 & 6.9 \\
\hline & \multicolumn{7}{|c|}{$\begin{array}{c}\text { (Annual changes in percent of broad money } \\
\text { beginning-period) }\end{array}$} \\
\hline Net foreign assets & -7.5 & -20.8 & 1.5 & 5.3 & -14.3 & -7.3 & -6.7 \\
\hline Net domestic assets & -0.3 & 4.6 & 6.4 & 0.1 & 13.2 & 2.9 & 1.9 \\
\hline Domestic credit & -1.1 & 5.7 & 9.3 & 3.1 & 16.9 & 2.2 & 3.4 \\
\hline Credit to the government (net) & -1.6 & 1.4 & 6.1 & 6.9 & 8.7 & -0.9 & 3.9 \\
\hline Credit to the economy & 0.1 & 4.6 & 4.5 & -1.3 & 3.2 & 6.3 & -1.3 \\
\hline \multirow[t]{2}{*}{ Money supply (M2) } & -7.7 & -16.2 & 7.9 & 5.4 & -1.1 & -4.3 & -4.8 \\
\hline & \multicolumn{7}{|c|}{ (Annual percentage changes) } \\
\hline Monetary base & -12.4 & -20.2 & 7.7 & 9.3 & -6.2 & -6.0 & -7.6 \\
\hline Credit to the economy & 0.5 & 17.6 & 12.2 & -3.5 & 9.2 & 16.3 & -2.8 \\
\hline Nominal GDP & 9.6 & 7.1 & 5.3 & 7.0 & 3.8 & 2.4 & -4.1 \\
\hline
\end{tabular}

Sources: Bank of Central African States (BEAC); and Fund staff estimates.

1/ GDP over five-quarter average of broad money. 
Table 20. Central African Republic: Summary Accounts of the Central Bank,

1997-2003

(In billions of CFA francs; end of period)

\begin{tabular}{|c|c|c|c|c|c|c|c|}
\hline & 1997 & 1998 & 1999 & 2000 & 2001 & 2002 & $\begin{array}{r}2003 \\
\text { Est. }\end{array}$ \\
\hline Total assets & 140.4 & 118.6 & 135.9 & 143.1 & 153.0 & 138.3 & 129.6 \\
\hline Foreign assets & 108.9 & 83.7 & 91.1 & 96.1 & 90.6 & 79.4 & 72.0 \\
\hline Gold & 1.9 & 1.8 & 2.1 & 2.1 & 2.4 & 2.4 & 2.4 \\
\hline SDRs & 0.0 & 0.0 & 0.0 & 0.0 & 0.0 & 0.0 & 0.1 \\
\hline CFA franc zone currency & 0.0 & 0.1 & 0.1 & 0.4 & 0.6 & 0.1 & 0.8 \\
\hline Operations account (credit balance) & 106.8 & 81.8 & 88.8 & 93.4 & 87.6 & 76.9 & 68.7 \\
\hline Other assets & 0.1 & 0.1 & 0.1 & 0.1 & 0.1 & 0.0 & 0.0 \\
\hline Credit to the government & 32.8 & 32.3 & 40.9 & 41.6 & 54.7 & 49.6 & 51.3 \\
\hline Current accounts (Article 21) & 10.4 & 11.3 & 14.4 & 11.9 & 12.1 & 12.6 & 15.5 \\
\hline Use of IMF credit & 11.1 & 9.8 & 15.3 & 15.1 & 22.9 & 20.9 & 19.7 \\
\hline Stand-By Arrangements & 6.5 & 1.9 & 0.0 & 0.0 & 0.0 & 0.0 & 0.0 \\
\hline SAF arrangements & 4.7 & 1.4 & 0.5 & 0.0 & 0.0 & 0.0 & 0.0 \\
\hline ESAF/PRGF arrangements & 0.0 & 6.5 & 14.8 & 15.1 & 22.9 & 20.9 & 19.7 \\
\hline Consolidated loans & 11.2 & 11.2 & 11.2 & 14.6 & 14.6 & 14.6 & 14.6 \\
\hline Other $1 /$ & 0.0 & 0.0 & 0.0 & 0.0 & 5.1 & 1.5 & 1.5 \\
\hline Credit to deposit money banks & 0.5 & 5.0 & 4.8 & 3.1 & 2.2 & 3.3 & 1.8 \\
\hline Other assets & -1.8 & -2.4 & -0.8 & 2.3 & 5.5 & 6.0 & 4.5 \\
\hline Total liabilities & 140.4 & 118.6 & 135.9 & 143.1 & 153.0 & 138.3 & 129.6 \\
\hline Monetary base & 95.3 & 76.1 & 82.0 & 89.6 & 84.0 & 79.0 & 73.0 \\
\hline Currency in circulation & 93.0 & 75.2 & 81.1 & 88.6 & 82.6 & 77.4 & 71.4 \\
\hline Currency issued & 93.5 & 75.9 & 81.1 & 89.3 & 83.4 & 78.5 & 72.2 \\
\hline Treasury cash & -0.1 & -0.1 & 0.0 & -0.1 & -0.1 & -0.1 & -0.1 \\
\hline Currency in banks & -0.4 & -0.5 & 0.0 & -0.5 & -0.7 & -0.9 & -0.7 \\
\hline Reserves & 2.4 & 0.9 & 0.8 & 1.0 & 1.4 & 1.5 & 1.6 \\
\hline Currency in banks & 0.4 & 0.5 & 0.5 & 0.5 & 0.7 & 0.9 & 0.7 \\
\hline Bank deposits with BEAC & 2.0 & 0.4 & 0.3 & 0.4 & 0.8 & 0.6 & 0.9 \\
\hline Foreign liabilities & 11.4 & 10.4 & 15.7 & 15.6 & 24.3 & 21.3 & 20.0 \\
\hline Current accounts of foreign institutions & 7.1 & 7.2 & 11.1 & 11.4 & 12.1 & 10.7 & 10.2 \\
\hline Deposits of regional institutions & 0.0 & 0.0 & 0.2 & 0.1 & 0.4 & 0.1 & 0.1 \\
\hline Use of IMF credit & 11.1 & 9.8 & 15.3 & 15.1 & 22.9 & 20.9 & 19.7 \\
\hline Other liabilities & -6.9 & -6.7 & -10.8 & -11.1 & -11.1 & -10.3 & -10.0 \\
\hline Central government deposits & 1.4 & 0.9 & 3.4 & 2.4 & 6.0 & 0.8 & 0.6 \\
\hline Other liabilities & 31.6 & 30.6 & 33.8 & 34.3 & 37.0 & 35.6 & 33.9 \\
\hline
\end{tabular}

Source: Bank of Central African States (BEAC).

1/ Including unpaid interest. 
Table 21. Central African Republic: Balance Sheet of Commercial Banks, 1997-2003

(In billions of CFA francs)

\begin{tabular}{|c|c|c|c|c|c|c|c|}
\hline & 1997 & 1998 & 1999 & 2000 & 2001 & 2002 & $\begin{array}{r}2003 \\
\text { Est. }\end{array}$ \\
\hline Total assets & 41.1 & 44.2 & 50.3 & 64.3 & 59.8 & 65.5 & 64.0 \\
\hline Reserves & 2.4 & 0.9 & 0.7 & 1.0 & 1.4 & 1.5 & 1.6 \\
\hline Foreign assets & 3.0 & 3.3 & 5.3 & 5.6 & 3.4 & 3.7 & 3.9 \\
\hline Credit to the central government & 1.6 & 1.6 & 1.8 & 6.8 & 7.1 & 6.4 & 8.2 \\
\hline Credit to other public agencies & 2.8 & 1.9 & 1.8 & 3.9 & 4.7 & 2.0 & 1.8 \\
\hline Credit to the economy & 30.5 & 35.9 & 40.3 & 38.9 & 42.5 & 49.4 & 48.0 \\
\hline Public enterprises & 6.4 & 8.0 & 14.2 & 8.0 & 8.0 & 8.1 & 8.9 \\
\hline Private sector & 24.2 & 28.0 & 26.1 & 30.9 & 34.5 & 41.3 & 39.1 \\
\hline Other assets & 0.7 & 0.6 & 0.3 & 8.2 & 0.8 & 2.6 & 0.5 \\
\hline Total liabilities & 41.1 & 44.2 & 50.3 & 64.3 & 59.8 & 65.5 & 64.0 \\
\hline Deposits & 30.4 & 27.0 & 30.4 & 32.7 & 32.9 & 34.4 & 34.0 \\
\hline Demand deposits & 14.2 & 12.3 & 14.6 & 13.2 & 16.6 & 17.3 & 17.6 \\
\hline Term and savings deposits & 9.1 & 10.0 & 9.6 & 9.1 & 10.5 & 10.2 & 10.9 \\
\hline Government deposits & 2.1 & 0.5 & 0.8 & 0.4 & 0.4 & 0.7 & 0.5 \\
\hline Deposits of other public institutions & 4.9 & 4.3 & 5.4 & 10.1 & 5.4 & 6.1 & 5.0 \\
\hline Foreign liabilities & 3.8 & 4.2 & 6.7 & 6.6 & 6.0 & 6.0 & 7.2 \\
\hline Short-term & 3.4 & 3.5 & 6.7 & 6.6 & 6.0 & 5.8 & 5.5 \\
\hline Of which: postal debt & 1.5 & 1.5 & 1.3 & 1.3 & 1.3 & 1.3 & 1.3 \\
\hline Medium- and long-term & 0.4 & 0.7 & 0.1 & 0.0 & 0.0 & 0.2 & 1.7 \\
\hline Credit from the BEAC & 0.5 & 5.0 & 4.8 & 3.1 & 2.2 & 3.3 & 1.8 \\
\hline Capital and reserves & 7.4 & 8.2 & 12.9 & 15.5 & 18.9 & 22.4 & 21.2 \\
\hline Other liabilities & -1.1 & -0.2 & -4.6 & 6.4 & -0.3 & -0.6 & -0.2 \\
\hline
\end{tabular}

Source: Bank of Central African States (BEAC). 
Table 22. Central African Republic: Balance of Payments, 1997-2003

(In millions of SDRs)

\begin{tabular}{|c|c|c|c|c|c|c|c|}
\hline & 1997 & 1998 & 1999 & 2000 & 2001 & 2002 & $\begin{array}{r}2003 \\
\text { Est. }\end{array}$ \\
\hline Current account & -21.2 & -45.6 & -12.8 & -22.1 & -19.2 & -19.3 & -41.0 \\
\hline Balance of goods & 12.0 & 3.4 & 12.3 & 28.4 & 27.5 & 21.8 & 6.2 \\
\hline Exports, f.o.b. & 114.1 & 111.3 & 108.4 & 118.4 & 111.6 & 112.6 & 83.8 \\
\hline Diamonds & 48.7 & 43.6 & 45.5 & 46.9 & 44.2 & 40.4 & 35.0 \\
\hline Wood products & 14.5 & 34.6 & 34.5 & 48.6 & 48.5 & 55.2 & 41.3 \\
\hline Cotton & 19.9 & 16.2 & 11.9 & 7.9 & 7.9 & 7.1 & 0.7 \\
\hline Coffee & 12.5 & 6.5 & 10.1 & 6.8 & 1.7 & 1.1 & 0.9 \\
\hline Other & 18.6 & 10.4 & 6.4 & 8.2 & 9.2 & 8.8 & 5.9 \\
\hline Imports, f.o.b. & -102.2 & -107.9 & -96.1 & -90.1 & -84.2 & -90.8 & -77.5 \\
\hline Petroleum products & -10.9 & -10.7 & -10.7 & -6.9 & -14.5 & -8.9 & -6.0 \\
\hline Public investment program & -17.7 & -26.6 & -20.9 & -15.6 & -4.7 & -14.4 & -3.9 \\
\hline Other & -73.6 & -70.6 & -64.5 & -67.6 & -65.0 & -67.5 & -67.6 \\
\hline Services (net) & -33.8 & -58.8 & -47.2 & -63.7 & -61.6 & -56.6 & -53.5 \\
\hline Credit & 61.1 & 42.2 & 32.3 & 23.3 & 14.1 & 12.9 & 11.8 \\
\hline Debit & -94.9 & -101.0 & -79.6 & -86.9 & -75.6 & -69.5 & -65.3 \\
\hline Income & -11.9 & -9.6 & -7.5 & -12.7 & -8.0 & -5.6 & -2.7 \\
\hline Credit & 1.2 & 3.1 & 4.0 & 2.9 & 4.1 & 4.1 & 4.6 \\
\hline Debit & -13.1 & -12.7 & -11.5 & -15.6 & -12.1 & -9.7 & -7.2 \\
\hline Current transfers (net) & 12.6 & 19.5 & 29.7 & 26.0 & 22.9 & 21.1 & 8.9 \\
\hline Capital account & 14.5 & 41.9 & 31.7 & 17.8 & 14.0 & 15.1 & 8.5 \\
\hline Project grants & 9.1 & 33.1 & 19.4 & 16.0 & 11.1 & 14.0 & 3.5 \\
\hline Program grants & 5.5 & 6.2 & 11.7 & 1.3 & 2.7 & 1.1 & 5.0 \\
\hline Debt cancellation & 0.0 & 2.5 & 0.5 & 0.5 & 0.2 & 0.0 & 0.0 \\
\hline Financial account & -50.0 & -43.2 & -39.5 & .33 .2 & -8.5 & -33.5 & -16.4 \\
\hline Public sector (net) & -11.6 & -12.3 & -14.7 & -6.9 & -4.5 & -14.5 & -14.1 \\
\hline Project disbursements & 3.4 & 0.7 & 1.6 & 0.7 & 1.4 & 6.7 & 3.7 \\
\hline Program disbursements & 0.0 & 0.0 & 0.0 & 9.3 & 10.4 & 1.5 & 6.2 \\
\hline Scheduled amortization & -14.9 & -13.0 & -16.3 & -16.9 & -16.3 & -22.7 & -23.9 \\
\hline Private sector (net) & -38.4 & -30.9 & -24.8 & -26.3 & -4.1 & -19.0 & -2.3 \\
\hline Errors and omissions & 23.1 & 7.5 & 6.8 & 23.8 & -16.0 & -2.6 & 10.1 \\
\hline Overall balance & -33.5 & -39.4 & -13.7 & -13.7 & -29.7 & -40.4 & -38.8 \\
\hline Net official reserves movements $1 /$ & 13.3 & 30.5 & -4.4 & -5.9 & 14.7 & 11.4 & 8.9 \\
\hline Net Fund credit & -5.4 & -1.3 & 4.6 & -0.6 & 7.8 & 0.0 & 0.0 \\
\hline Purchases and loans & 0.0 & 8.2 & 8.2 & 0.0 & 7.8 & 0.0 & 0.0 \\
\hline Repayments (cash basis) & -5.4 & -9.6 & -3.6 & -0.6 & 0.0 & 0.0 & 0.0 \\
\hline Other reserves (increase -) & 18.7 & 31.8 & -9.0 & -5.3 & 6.9 & 11.4 & 8.9 \\
\hline Exceptional funancing & 20.2 & 8.9 & 18.1 & 19.6 & 15.0 & 29.0 & 29.9 \\
\hline Debt rescheduling & 0.0 & 93.0 & 17.4 & 13.3 & 6.6 & 0.0 & 0.0 \\
\hline Debt-payments arrears (reduction -) & 20.2 & -84.1 & 0.6 & 6.3 & 8.4 & 29.0 & 29.9 \\
\hline
\end{tabular}

Sources: C.A.R. authorities; Bank of Central African States (BEAC); and Fund staff estimates.

1/ Based on definitions consistent with the IMF's Balance of Payments Manual, 5Th edition. 
Table 23. Central African Republic: Balance of Payments, 1997-2003 1/

(In billions of CFA francs, unless otherwise indicated )

\begin{tabular}{|c|c|c|c|c|c|c|c|}
\hline & 1997 & 1998 & 1999 & 2000 & 2001 & 2002 & $\begin{array}{r}2003 \\
\text { Est. }\end{array}$ \\
\hline Current account & -17.0 & -36.5 & -10.7 & -20.7 & -17.9 & -17.4 & -33.3 \\
\hline Balance of goods & 9.6 & 2.7 & 10.4 & 26.6 & 25.6 & 19.6 & 5.0 \\
\hline Exports, f.o.b. & 91.7 & 89.1 & 91.1 & 110.9 & 104.1 & 101.3 & 67.9 \\
\hline Diamonds & 39.1 & 34.9 & 38.2 & 43.9 & 41.2 & 36.3 & 28.4 \\
\hline Wood products & 11.7 & 27.7 & 29.0 & 45.5 & 45.3 & 49.6 & 33.5 \\
\hline Cotton & 16.0 & 13.0 & 10.0 & 7.4 & 7.4 & 6.4 & 0.6 \\
\hline Coffee & 10.0 & 5.2 & 8.5 & 6.3 & 1.6 & 1.0 & 0.7 \\
\hline Other & 14.9 & 8.3 & 5.4 & 7.7 & 8.6 & 7.9 & 4.8 \\
\hline Imports, f.o.b. & -82.1 & -86.3 & -80.8 & -84.3 & -78.5 & -81.7 & -62.9 \\
\hline Petroleum products & -8.8 & -8.5 & -9.0 & -6.4 & -13.5 & -8.0 & -4.9 \\
\hline Public investment program & -14.2 & -21.3 & -17.6 & -14.6 & -4.4 & -13.0 & -3.2 \\
\hline Other & -59.1 & -56.5 & -54.2 & -63.3 & -60.6 & -60.7 & -54.8 \\
\hline Services (net) & -27.1 & -47.1 & -39.7 & -59.6 & -57.4 & -50.9 & -43.4 \\
\hline Credit & 49.1 & 33.8 & 27.2 & 21.8 & 13.1 & 11.6 & 9.6 \\
\hline Debit & -76.3 & -80.9 & -66.9 & -81.4 & -70.5 & -62.5 & -53.0 \\
\hline Income & -9.6 & -7.7 & -6.3 & -11.9 & -7.5 & -5.1 & -2.2 \\
\hline Credit & 0.9 & 2.5 & 3.4 & 2.7 & 3.8 & 3.7 & 3.7 \\
\hline Debit & $\begin{array}{r}-10.5 \\
\text { v.u }\end{array}$ & $\begin{array}{r}-10.2 \\
\text { v.u }\end{array}$ & $\begin{array}{r}-9.7 \\
\text { v.u }\end{array}$ & $\begin{array}{r}-14.6 \\
\text { U. }\end{array}$ & $\begin{array}{r}-11.3 \\
\text { U.U }\end{array}$ & $\begin{array}{r}-8.8 \\
\text { U.U }\end{array}$ & $\begin{array}{r}-5.9 \\
\text { U.u }\end{array}$ \\
\hline Current transfers (net) & 10.1 & 15.6 & 24.9 & 24.3 & 21.3 & 19.0 & 7.2 \\
\hline Capital account & 11.7 & $\begin{array}{r}33.5 \\
\text { v.v }\end{array}$ & $\begin{array}{r}26.6 \\
v . v\end{array}$ & $\begin{array}{r}16.7 \\
\text { U.u }\end{array}$ & $\begin{array}{r}13.1 \\
\text { v.u }\end{array}$ & $\begin{array}{r}13.6 \\
\text { v.u }\end{array}$ & $\begin{array}{l}6.9 \\
\text { v. }\end{array}$ \\
\hline Project grants & 7.3 & 26.5 & 16.3 & 15.0 & 10.4 & 12.6 & 2.8 \\
\hline Program grants & 4.4 & 5.0 & 9.9 & 1.2 & 2.5 & 1.0 & 4.1 \\
\hline Debt cancellation & 0.0 & 2.0 & 0.4 & 0.5 & 0.2 & 0.0 & 0.0 \\
\hline Financial account & -40.1 & -34.6 & -33.2 & -31.1 & -8.0 & -30.2 & -13.3 \\
\hline Public sector (net) & -9.3 & -9.8 & -12.3 & -6.5 & -4.2 & -13.1 & -11.4 \\
\hline Project disbursements & 2.7 & 0.5 & 1.4 & 0.7 & 1.3 & 6.0 & 3.0 \\
\hline Program disbursements & 0.0 & 0.0 & 0.0 & 8.7 & 9.7 & 1.3 & 5.0 \\
\hline Scheduled amortization & -12.0 & -10.4 & -13.7 & -15.9 & -15.2 & -20.4 & -19.4 \\
\hline Private sector (net) & -30.8 & -24.8 & -20.8 & -24.6 & -3.8 & -17.1 & -1.9 \\
\hline Errors and omissions & 18.5 & 6.0 & 5.7 & 22.2 & -14.9 & -2.3 & 8.2 \\
\hline Overall balance & -26.9 & -31.5 & -11.5 & -12.8 & -27.7 & -36.3 & -31.5 \\
\hline Net official reserves movements $1 /$ & 10.7 & 24.4 & -3.7 & -5.5 & 13.7 & 10.3 & 7.2 \\
\hline Net Fund credit & -4.4 & -1.1 & 3.9 & -0.6 & 7.3 & 0.0 & 0.0 \\
\hline Purchases and loans & 0.0 & 6.6 & 6.9 & 0.0 & 7.3 & 0.0 & 0.0 \\
\hline Repayments (cash basis) & -4.4 & -7.7 & -3.0 & -0.6 & 0.0 & 0.0 & 0.0 \\
\hline Other reserves (increase -) & 15.0 & 25.5 & -7.5 & -5.0 & 6.5 & 10.3 & 7.2 \\
\hline Exceptional financing & 16.2 & 7.1 & 15.2 & 18.3 & 14.0 & 26.1 & 24.3 \\
\hline Debt rescheduling & 0.0 & 74.4 & 14.7 & 12.4 & 6.2 & 0.0 & 0.0 \\
\hline Debt payments arrears (reduction -) & 16.2 & -67.3 & 0.5 & 5.9 & 7.8 & 26.1 & 24.3 \\
\hline \multicolumn{8}{|l|}{ Memorandum items: } \\
\hline $\begin{array}{l}\text { Gross official reserves } \\
\text { (at end of period) }\end{array}$ & 108.6 & 83.1 & 90.7 & 95.7 & 89.2 & 78.9 & 71.7 \\
\hline Current account (in percent of GDP) & -3.0 & -6.0 & -1.7 & -3.0 & -2.5 & -2.4 & -4.8 \\
\hline
\end{tabular}

Sources: C.A.R. authorities; Bank of Central African States (BEAC); and Fund staff estimates.

1/ Based on definitions consistent with the IMF's Balance of Payments Manual, 5Th edition. 
Table 24. Central African Republic: Composition of Exports, 1997-2003

(Value in billions of CFA francs; volumes in thousands of tons; unit values in CFA francs per kilogram, unless specified otherwise)

\begin{tabular}{|c|c|c|c|c|c|c|c|}
\hline & 1997 & 1998 & 1999 & 2000 & 2001 & 2002 & $\begin{array}{r}2003 \\
\text { Est. }\end{array}$ \\
\hline Total exports, value & 91.7 & 89.1 & 91.1 & 110.9 & 104.1 & 101.3 & 67.9 \\
\hline \multicolumn{8}{|l|}{ Rough diamonds } \\
\hline Value & 39.1 & 34.9 & 38.2 & 43.9 & 41.2 & 36.3 & 28.4 \\
\hline Volume $1 /$ & 473.9 & 420.0 & 431,1 & 461.0 & 449.3 & 414.8 & 329.6 \\
\hline Unit value $2 /$ & 82,500 & 83,000 & 88,700 & 95,300 & 91,700 & 87,600 & 86,200 \\
\hline \multicolumn{8}{|l|}{ Coffee $3 /$} \\
\hline Value & 10.0 & 5.2 & 8.5 & 6.3 & 1.6 & 1.0 & 0.7 \\
\hline Volume & 12.7 & 6.4 & 11.5 & 12.1 & 5.6 & 5.7 & 2.0 \\
\hline Unit value & 789.0 & 812.0 & 739.9 & 524.2 & 289.1 & 179.6 & 358.0 \\
\hline \multicolumn{8}{|l|}{ Wood products } \\
\hline Value & 11.7 & 27.7 & 29.0 & 45.5 & 45.3 & 49.6 & 33.5 \\
\hline Volume $4 /$ & 111.3 & 189.4 & 218.3 & 315.1 & 335.7 & 381.1 & 275.7 \\
\hline Unit value $5 /$ & 104.5 & 145.9 & 132.2 & 144.4 & 134.4 & 130.4 & 121.2 \\
\hline \multicolumn{8}{|l|}{ Cotton } \\
\hline Value & 16.0 & 13.0 & 10.0 & 7.4 & 7.4 & 6.4 & 0.6 \\
\hline Volume & 18.0 & 17.4 & 13.5 & 11.2 & 9.9 & 12.3 & 0.9 \\
\hline Unit value & 886.7 & 745.9 & 741.5 & 656.4 & 746.6 & 520.7 & 621.2 \\
\hline \multicolumn{8}{|l|}{ Tobacco } \\
\hline Value & 0.3 & 0.2 & 0.2 & 0.2 & 0.1 & 0.1 & 0.1 \\
\hline Volume & 0.3 & 0.2 & 0.3 & 0.2 & 0.1 & 0.1 & 0.1 \\
\hline Unit value & 911 & 852 & 822 & 919 & 948 & 962 & 825 \\
\hline \multicolumn{8}{|l|}{ Miscellaneous } \\
\hline Value & 14.6 & 8.1 & 5.1 & 7.5 & 8.5 & 7.8 & 4.7 \\
\hline
\end{tabular}

Sources: C.A.R. authorities; Bank of Central African States (BEAC); and Fund staff estimates.

1/ In thousands of carats.

2/ In CFA francs per carat.

3/ Includes reexports.

4/ In thousands of cubic meters.

5/ In CFA francs per cubic meter. 
Table 25. Central African Republic: Export, Import Indices and Terms of Trade, 1997-2003 1/

\begin{tabular}{|c|c|c|c|c|c|c|c|}
\hline & 1997 & 1998 & 1999 & 2000 & 2001 & 2002 & $\begin{array}{r}2003 \\
\text { Est. }\end{array}$ \\
\hline & \multicolumn{7}{|c|}{ (Indices, 1995=100) $1 /$} \\
\hline \multicolumn{8}{|l|}{ Exports 2/ } \\
\hline Value & 98.8 & 96.0 & 98.2 & 119.6 & 112.2 & 109.2 & 73.3 \\
\hline Volume & 105.8 & 97.9 & 102.1 & 118.6 & 111.7 & 117.9 & 76.9 \\
\hline Unit value & 93.4 & 98.1 & 96.2 & 100.8 & 100.5 & 92.6 & 95.3 \\
\hline \multicolumn{8}{|l|}{ Imports } \\
\hline Value & 90.8 & 95.5 & 89.3 & 93.3 & 86.8 & 90.3 & 69.6 \\
\hline Volume & 86.8 & 93.2 & 86.2 & 81.7 & 70.8 & 76.5 & 71.7 \\
\hline Unit value & 104.6 & 102.4 & 103.7 & 114.1 & 122.7 & 118.1 & 97.0 \\
\hline Terms of trade (CFA basis) & 89.4 & 95.7 & 92.8 & 88.4 & 81.9 & 78.4 & 98.2 \\
\hline & \multicolumn{7}{|c|}{ (Annual percentage change) $1 /$} \\
\hline \multicolumn{8}{|l|}{ Exports $2 /$} \\
\hline Value & 29.5 & -2.9 & 2.3 & 21.7 & -6.2 & -2.7 & -32.9 \\
\hline Volume & 23.9 & -7.4 & 4.3 & 16.2 & -5.8 & 5.6 & -34.8 \\
\hline Unit value & 4.5 & 5.0 & -1.9 & 4.8 & -0.4 & -7.8 & 2.9 \\
\hline \multicolumn{8}{|l|}{ Imports } \\
\hline Value & 11.4 & 5.2 & -6.5 & 4.4 & -6.9 & 4.1 & -23.0 \\
\hline Volume & 8.9 & 7.4 & -7.6 & -5.1 & -13.4 & 8.1 & -6.3 \\
\hline Unit value & 2.3 & -2.0 & 1.2 & 10.1 & 7.5 & -3.7 & -17.9 \\
\hline Terms of trade (CFA basis) & 2.1 & 7.1 & -3.0 & -4.8 & -7.3 & -4.3 & 25.3 \\
\hline
\end{tabular}

Sources: C.A.R. authorities; Bank of Central African States (BEAC); IMF's World Economic Outlook (WEO) database; and Fund staff estimates.

1/ Based on unit values in CFA francs.

$2 /$ Includes reexports. 
Table 26. Central African Republic: Balance of Payments-Selected

Components of Services, Income, and Transfers, 1997-2003

(In millions of SDRs)

\begin{tabular}{|c|c|c|c|c|c|c|c|}
\hline & 1997 & 1998 & 1999 & 2000 & 2001 & 2002 & $\begin{array}{r}2003 \\
\text { Est. }\end{array}$ \\
\hline Services (net) & -33.8 & -58.8 & -47.2 & -63.7 & -61.6 & -56.6 & -53.5 \\
\hline Credit & 61.1 & 42.2 & 32.3 & 23.3 & 14.1 & 12.9 & 11.8 \\
\hline Freight and insurance & 0.3 & 0.9 & 0.4 & 0.3 & 0.5 & 0.3 & 0.2 \\
\hline Other transport & 5.9 & 0.5 & 1.2 & 0.7 & 0.8 & 0.8 & 0.7 \\
\hline Travel & 1.5 & 2.7 & 6.1 & 3.5 & 4.2 & 2.3 & 2.5 \\
\hline Other private services & 0.8 & 2.9 & 1.7 & 2.4 & 1.9 & 1.4 & 1.5 \\
\hline Government services & 52.6 & 35.3 & 22.9 & 16.5 & 6.7 & 8.0 & 6.9 \\
\hline Debit & -94.9 & -101.0 & -79.6 & -86.9 & -75.6 & -69.5 & -65.3 \\
\hline Freight and insurance & -36.4 & -37.3 & -33.8 & -34.0 & -32.5 & -31.2 & -25.9 \\
\hline Petroleum products & -1.9 & -1.9 & -1.9 & -2.9 & -6.7 & -3.9 & -3.7 \\
\hline Other freight and insurance & -34.5 & -35.5 & -31.9 & -31.1 & -25.8 & -27.3 & -22.2 \\
\hline Other transport & -8.5 & -9.5 & -9.3 & -10.3 & -11.7 & -11.0 & -12.1 \\
\hline Travel & -36.8 & -32.6 & -24.5 & -24.8 & -23.1 & -22.8 & -24.7 \\
\hline Other private services & -13.2 & -20.8 & -11.1 & -17.1 & -8.2 & -4.2 & -2.5 \\
\hline Public administration services & -0.1 & -0.8 & -0.9 & -0.7 & -0.2 & -0.2 & -0.2 \\
\hline Income (net) & -11.9 & -9.6 & -7.5 & -12.7 & -8.0 & -5.6 & -2.7 \\
\hline Credit & 1.2 & 3.1 & 4.0 & 2.9 & 4.1 & 4.1 & 4.6 \\
\hline Compensation of employees & 0.4 & 3.0 & 3.6 & 2.2 & 3.4 & 3.8 & 4.2 \\
\hline Investment income & 0.8 & 0.1 & 0.4 & 0.6 & 0.6 & 0.3 & 0.4 \\
\hline Debit & -13.1 & -12.7 & -11.5 & -15.6 & -12.1 & -9.7 & -7.2 \\
\hline Compensation of employees & 0.3 & -0.3 & -0.2 & -0.1 & 0.0 & 0.0 & 0.0 \\
\hline Investment income & -13.4 & -12.4 & -11.3 & -1.5 .5 & -12.1 & -9.7 & -7.2 \\
\hline Interest on public sector debt $1 /$ & -8.1 & -9.0 & -9.7 & -11.0 & -9.2 & -8.3 & -6.3 \\
\hline Public debt (budget concept) & -7.6 & -8.6 & -9.6 & -10.9 & -9.1 & -8.2 & -6.1 \\
\hline IMF & -0.5 & -0.3 & -0.1 & -0.1 & -0.1 & -0.1 & -0.1 \\
\hline Private sector & -5.3 & -3.4 & -1.5 & -4.5 & -2.9 & -1.4 & -1.0 \\
\hline Current transfers (net) & 12.6 & 19.5 & 29.7 & 26.0 & 22.9 & 21.1 & 8.9 \\
\hline Private (net) & -7.1 & -6.7 & -1.7 & 0.8 & 2.6 & 1.8 & 3.3 \\
\hline Official (net) & 19.7 & 26.2 & 31.4 & 25.1 & 20.3 & 19.3 & 5.6 \\
\hline
\end{tabular}

Sources: Bank of Central African States (BEAC); and Fund staff estimates.

1/ Scheduled interest, including IMF charges. 
Table 27. Central African Republic: Direction of Trade, 1997-2002

(In percent of total)

\begin{tabular}{|c|c|c|c|c|c|c|}
\hline & 1997 & 1998 & 1999 & 2000 & 2001 & 2002 \\
\hline \multicolumn{7}{|l|}{ Exports, f.o.b. } \\
\hline African countries & 5.9 & 2.5 & 1.5 & 1.6 & 3.0 & 3.2 \\
\hline European Union & 93.9 & 84.7 & 78.7 & 85.8 & 79.8 & 88.0 \\
\hline Belgium & $\ldots$ & 67.5 & 64.5 & 70.1 & 59.1 & 70.8 \\
\hline France & 22.8 & 3.8 & 3.1 & 2.5 & 3.0 & 2.8 \\
\hline Germany & 0.8 & 0.6 & 1.3 & 2.4 & 1.4 & 0.9 \\
\hline Italy & 0.1 & 2.6 & 1.4 & 1.5 & 4.0 & 4.0 \\
\hline Spain & 0.0 & 8.9 & 6.1 & 6.4 & 9.4 & 6.8 \\
\hline United Kingdom & 4.8 & 0.1 & 0.4 & 0.1 & 0.2 & 0.2 \\
\hline Other European countries & $\ldots$ & 1.6 & 10.5 & 1.8 & 1.2 & 0.9 \\
\hline United States & 0.1 & 1.1 & 0.7 & 1.0 & 1.3 & 1.1 \\
\hline Canada & 0.0 & 0.1 & 0.1 & 0.6 & 0.0 & 0.1 \\
\hline Other (Western Hemisphere) & 0.0 & 0.3 & 0.7 & 0.4 & 0.2 & 0.1 \\
\hline Asia & 0.1 & 9.7 & 7.8 & 8.7 & 14.5 & 6.5 \\
\hline Japan & 0.1 & 0.3 & 0.2 & 0.3 & 1.0 & 0.6 \\
\hline Total & 100.0 & 100.0 & 100.0 & 100.0 & 100.0 & 100.0 \\
\hline \multicolumn{7}{|l|}{ Imports, c.i.f. } \\
\hline African countries & 24.8 & 21.1 & 22.7 & 19.5 & 16.2 & 18.7 \\
\hline European Union & 63.4 & 58.7 & 61.0 & 63.8 & 63.2 & 64.4 \\
\hline Belgium & 5.2 & 6.0 & 8.7 & 4.7 & 4.1 & 4.4 \\
\hline France & 46.2 & 41.4 & 41.2 & 46.7 & 38.9 & 42.7 \\
\hline Germany & 5.2 & 2.6 & 3.6 & 3.9 & 5.1 & 4.4 \\
\hline Italy & 1.1 & 1.6 & 1.5 & 1.2 & 2.4 & 2.2 \\
\hline Spain & 0.5 & 0.6 & 0.6 & 0.8 & 6.7 & 4.5 \\
\hline United Kingdom & 1.9 & 0.8 & 1.1 & 1.0 & 3.2 & 3.2 \\
\hline Other European countries & 1.3 & 4.5 & 3.6 & 3.6 & 1.0 & 1.3 \\
\hline United States & 3.7 & 3.9 & 3.1 & 2.7 & 3.9 & 7.3 \\
\hline Canada & 0.2 & 0.0 & 0.3 & 0.0 & 0.2 & 0.3 \\
\hline Other (Western Hemisphere) & 0.8 & 0.8 & 1.1 & 1.3 & 1.8 & 1.8 \\
\hline Asia & 5.8 & 11.0 & 8.2 & 9.1 & 13.6 & 6.2 \\
\hline Japan & 1.8 & 4.2 & 3.8 & 4.7 & 3.3 & 2.8 \\
\hline Total & 100.0 & 100.0 & 100.0 & 100.0 & 100.0 & 100.0 \\
\hline
\end{tabular}

Source: IMF, Direction of Trade Statistics; and C.A.R. authorities. 
Table 28. Central African Republic: External Debt Outstanding and Debt-Service Flows, 1997-2003 1/

\begin{tabular}{|c|c|c|c|c|c|c|c|}
\hline & 1997 & 1998 & 1999 & 2000 & 2001 & 2002 & $\begin{aligned} 2003 \\
\text { Est. }\end{aligned}$ \\
\hline & \multicolumn{7}{|c|}{ (In billions of CFA francs) } \\
\hline \multicolumn{8}{|l|}{ Total medium- and long-tenn debt } \\
\hline outstanding, including arrears & 539.6 & 519.8 & 540.9 & 562.4 & 688.3 & 683.4 & 670.7 \\
\hline Of which: excluding IMF & 526.9 & 509.0 & 525.6 & 547.3 & 665.4 & 661.7 & 651.0 \\
\hline \multicolumn{8}{|l|}{ Medium- and long-term debt, } \\
\hline excluding arrears & 453.8 & 500.1 & 521.6 & 537.2 & 555.0 & 523.0 & 488.6 \\
\hline $\mathrm{IMF}$ & 10.9 & 9.9 & 15.3 & 15.1 & 22.9 & 21.7 & 19.7 \\
\hline Other multilateral creditors & 353.7 & 331.3 & 327.7 & 327.4 & 329.4 & 324.5 & 319.2 \\
\hline Paris Club creditors & 26.4 & 31.4 & 32.1 & 33.9 & 37.1 & 37.1 & 37.1 \\
\hline Other official creditors & 62.8 & 101.6 & 120.6 & 134.8 & 138.4 & 138.4 & 138.4 \\
\hline Other & 0.0 & 25.9 & 25.9 & 25.9 & 25.0 & 25.0 & 25.0 \\
\hline Arrears outstanding & 85.8 & 19.7 & 19.4 & 25.2 & 133.4 & 160.4 & 182.1 \\
\hline IMF & 1.8 & 0.8 & 0.0 & 0.0 & 0.0 & 0.0 & 0.0 \\
\hline Other multilateral creditors & 16.5 & 18.8 & 16.9 & 21.8 & 31.2 & 43.7 & 53.1 \\
\hline Paris Club creditors & 6.0 & 0.0 & 0.2 & 0.4 & 19.0 & 19.0 & 19.0 \\
\hline Other official creditors & 36.0 & 0.0 & 0.0 & 0.2 & 75.5 & 75.5 & 75.5 \\
\hline Other & 25.4 & 0.0 & 2.2 & 2.8 & 3.0 & 3.0 & 3.0 \\
\hline Debt service due before debt relief & 24.7 & 24.3 & 24.0 & 26.7 & 23.4 & 27.4 & 24.0 \\
\hline Interest & 6.6 & 7.2 & 8.2 & 10.3 & 8.2 & 7.0 & 4.6 \\
\hline Principal & 18.2 & 17.1 & 15.8 & 16.4 & 15.2 & 20.4 & 19.4 \\
\hline Debt relief on current maturities & 0.0 & 4.2 & 9.4 & 12.9 & 6.4 & 0.0 & 0.0 \\
\hline Interest & 0.0 & 1.8 & 4.7 & 5.3 & 2.8 & 0.0 & 0.0 \\
\hline Principal & 0.0 & 2.4 & 4.6 & 7.6 & 3.6 & 0.0 & 0.0 \\
\hline Debt service due after debt relief & 24.7 & 20.0 & 14.7 & 13.8 & 17.1 & 27.4 & 24.0 \\
\hline Interest & 6.6 & 5.4 & 3.4 & 4.9 & 5.4 & 7.0 & 4.6 \\
\hline Principal & 18.2 & 14.6 & 11.2 & 8.9 & 11.6 & 20.4 & 19.4 \\
\hline Memorandum items: & & & & ercent) & & & \\
\hline \multicolumn{8}{|c|}{ External public debt (including arrears)/GDP } \\
\hline Including IMF & 95.3 & 85.7 & 84.7 & 82.3 & 97.0 & 94.1 & 96.3 \\
\hline Excluding IMF & 93.1 & 83.9 & 82.3 & 80.1 & 93.8 & 91.1 & 93.5 \\
\hline \multicolumn{8}{|c|}{$\begin{array}{l}\text { Extemal public debt (including arrears)/ } \\
\text { exports of goods and services }\end{array}$} \\
\hline Including IMF & 383.3 & 423.1 & 457.3 & 423.9 & 587.4 & 605.5 & 864.9 \\
\hline Excluding IMF & 374.3 & 414.4 & 444.4 & 412.5 & 567.8 & 586.2 & 839.5 \\
\hline \multicolumn{8}{|c|}{$\begin{array}{l}\text { Debt-service ratio (including IMF; relative } \\
\text { to exports of goods and services) }\end{array}$} \\
\hline Before debt relief & 17.6 & 19.7 & 20.3 & 20.1 & 20.0 & 24.3 & 31.0 \\
\hline Interest & 4.7 & 5.8 & 6.9 & 7.8 & 7.0 & 6.2 & 6.0 \\
\hline Principal & 12.9 & 13.9 & 13.4 & 12.4 & 13.0 & 18.1 & 25.0 \\
\hline After debt relief & 17.6 & 16.3 & 12.4 & 10.4 & 14.6 & 24.3 & 31.0 \\
\hline Interest & 4.7 & 4.4 & 2.9 & 3.7 & 4.6 & 6.2 & 6.0 \\
\hline Principal & 12.9 & 11.9 & 9.5 & 6.7 & 9.9 & 18.1 & 25.0 \\
\hline \multicolumn{8}{|l|}{ Debt service due/government receipts } \\
\hline Before debt relief & 54.9 & 43.0 & 40.2 & 44.1 & 37.1 & 34.9 & 44.8 \\
\hline After debt relief & 54.9 & 35.6 & 24.5 & 22.8 & 27.0 & 34.9 & 44.8 \\
\hline \multicolumn{8}{|l|}{ Debt service due/GDP } \\
\hline Before debt relief & 4.4 & 4.0 & 3.8 & 3.9 & 3.3 & 3.8 & 3.5 \\
\hline After debt relief & 4.4 & 3.3 & 2.3 & 2.0 & 2.4 & 3.8 & 3.5 \\
\hline Net transfer of resources/GDP & 5.4 & 8.1 & 8.5 & 6.4 & 5.8 & 5.6 & 3.3 \\
\hline
\end{tabular}

Sources: C.A.R. authorities.

1/ For certain years, treatment of debt relief and arrears differs from that presented in Table 15. 
Table 29. Central African Republic: Debt Service and Arrears on

External Public and Publicly Guaranteed Debt, 1997-2003

(In billions of CFA francs)

\begin{tabular}{|c|c|c|c|c|c|c|c|}
\hline & 1997 & 1998 & 1999 & 2000 & 2001 & 2002 & $\begin{array}{r}2003 \\
\text { Est. } \\
\end{array}$ \\
\hline Debt service due after debt relief & 24.7 & 20.0 & 14.7 & 13.8 & 17.1 & 27.4 & 24.0 \\
\hline Multilateral creditors & 14.3 & 15.3 & 11.5 & 12.4 & 9.3 & 12.8 & 12.2 \\
\hline $\mathrm{IMF}$ & 6.6 & 7.0 & 2.3 & 0.6 & 0.1 & 0.1 & 0.1 \\
\hline Other multilaterals & 7.7 & 8.4 & 9.2 & 11.8 & 9.2 & 12.7 & 12.1 \\
\hline Bilateral creditors & 9.6 & 4.2 & 0.9 & 0.8 & 6.8 & 13.9 & 11.9 \\
\hline Other & 0.9 & 0.5 & 2.3 & 0.6 & 1.3 & 1.2 & 0.4 \\
\hline Total cash payments & 6.7 & 16.4 & 9.2 & 7.9 & 9.6 & 1.8 & 0.2 \\
\hline Multilateral creditors & 6.7 & 15.9 & 8.5 & 7.5 & 7.7 & 1.2 & 0.1 \\
\hline IMF & 4.8 & 7.9 & 3.1 & 0.6 & 0.1 & 0.1 & 0.1 \\
\hline Other multilaterals & 1.9 & 7.9 & 5.4 & 6.9 & 7.7 & 1.1 & 0.0 \\
\hline Bilateral creditors & 0.0 & 0.5 & 0.7 & 0.4 & 1.8 & 0.6 & 0.1 \\
\hline Other & 0.0 & 0.0 & 0.0 & 0.0 & 0.0 & 0.0 & 0.0 \\
\hline Debt relief on arrears & 0.0 & 72.2 & 5.7 & 0.0 & 0.0 & 0.0 & 0.0 \\
\hline Multilateral creditors & 0.0 & 0.0 & 5.7 & 0.0 & 0.0 & 0.0 & 0.0 \\
\hline $\mathrm{IMF}$ & 0.0 & 0.0 & 0.0 & 0.0 & 0.0 & 0.0 & 0.0 \\
\hline Other multilaterals & 0.0 & 0.0 & 5.7 & 0.0 & 0.0 & 0.0 & 0.0 \\
\hline Bilateral creditors & 0.0 & 46.3 & 0.0 & 0.0 & 0.0 & 0.0 & 0.0 \\
\hline Other & 0.0 & 25.9 & 0.0 & 0.0 & 0.0 & 0.0 & 0.0 \\
\hline Net change in arrears & 18.0 & -68.0 & -0.3 & 5.9 & 7.8 & 26.1 & 24.3 \\
\hline Multilateral creditors & 7.6 & -0.5 & -2.8 & 4.9 & 1.6 & 11.6 & 12.0 \\
\hline IMF & 1.8 & -0.9 & -0.9 & 0.0 & 0.0 & 0.0 & 0.0 \\
\hline Other multilaterals & 5.8 & 0.4 & -1.9 & 4.9 & 1.6 & 11.6 & 12.0 \\
\hline Bilateral creditors & 9.6 & -42.1 & 0.2 & 0.4 & 4.9 & 13.3 & 11.8 \\
\hline Other & 0.9 & -25.4 & 2.2 & 0.6 & 1.3 & 1.2 & 0.4 \\
\hline \multicolumn{8}{|l|}{ Memorandum items: } \\
\hline Arrears at beginning of period & 68.2 & 85.8 & 19.7 & 19.4 & 25.2 & 133.4 & 160.4 \\
\hline Accumulation & 18.0 & 8.7 & 6.4 & 6.4 & 8.8 & 27.0 & 24.3 \\
\hline Cash settlements & 0.0 & 4.7 & 1.1 & 0.5 & 1.0 & 0.9 & 0.0 \\
\hline Rescheduling and cancellations & 0.0 & 72.2 & 5.7 & 0.0 & 0.0 & 0.0 & 0.0 \\
\hline Arrears at end of period (before revaluation) & 86.2 & 17.6 & 19.3 & 25.2 & 33.0 & 159.4 & 184.6 \\
\hline
\end{tabular}

Sources: C.A.R. authorities. 
Table 30. Central African Republic: Summary of the Tax System, End of 2002 and Tax Act of 2003

(All amounts in CFA francs)

Deductions

\section{Central Administration}

1. Taxes on income and profits

1.1 Taxes on companies

1.1.1 Tax on companies (impôt sur les sociétés)

[General Tax Code (Code général des impôts), 1962, amended by Order No. 74-013 of January 24, 1974]. Many other Tax Acts amended the tax on companies prior to the CEMAC Directive (Directive No.

02/01/UEAC-050 CM-06 revising Document 3/72 -153 - UDEAC of December 22, 1972 creating the tax on companies)

1.1.2 Minimum tax on companies (impôt minimum forfaitaire des sociétés - IMF)
Annual tax on profits of companies from industrial, commercial, agricultural or noncommercial activities.

Realized capital gains are included in income. Nonresident companies are taxed on their income from sources within the Central African Republic.

Profits are declared by May 1 of the following year, and tax is paid in three equal installments (on May 15, June 15, and July 15).

Levied as advanced payment of company tax. No refunds are made. Based on the previous year's revenues. Declared before February 15 and paid in three equal installments on February 15, March 15, and April 15. New features: The minimum tax on companies is withheld at the source for:

a) Import companies: source withholding of $1 \%$ on the CIF value plus customs duties

b) Export companies: source withholding at the rate of $2 \%$ on the $\mathrm{FOB}$ value for cotton and the FOB-C.A.R. value for wood. (Art. 40 Tax Act of 2002). Withheld at the source at the rate of $3 \%$ of the customs value for diamonds and gold (Article 64 Tax Act of 2003).
Agricultural and consumer cooperatives.

Business-related expenses are deductible.

Straight-line depreciation ranging from $5 \%$ to $33.3 \%$ is allowed.

Accelerated depreciation is also provided for
Agriculture sector: $20 \%$

Other sectors: $30 \%$

Additional centimes are eliminated.

New features (first bracket)

Art. 29 Tax Act of 2003

Turnover (Chiffre d'affaires - CA) less than or equal to CFAF 100 million -- lump sum of CFAF $1,500,000$

CFAF $101<$ CA $<$ CFAF 200 million $=2 \%$

CFAF $201<$ CA $<$ CFAF 500 million $=1.85 \%$

$\mathrm{CA}>\mathrm{CFAF} 500$ million $=1.70 \%$ 
Table 30. Central African Republic: Summary of the Tax System, End of 2002 and Tax Act of 2003

(All amounts in CFA francs)

1.2 Taxes on individuals

1.2.1 Tax on industrial and commercial profits (impôt sur les bénéfices industriels et commerciaux)

1.2.2 Minimum tax on individuals (minimum fiscal)
The minimum tax on individuals is

established for the fiscal year of its payment (Law 95.05). The tax is paid jointly with the business license in advance by taxpayers in three monthly installments, and without prior notice, before March 31 of each fiscal year. If activities are commenced during a year, and the amount of the revenues or receipts is less than 6 million, the taxable minimum will be calculated for that year as of the first day of the quarter in which the taxpayer commenced doing business (Art 15 Tax Act of 98.001).

The minimum tax on individuals is

determined as follows:

Total revenues, all taxes included, or receipts obtained during the fiscal year:

- Receipts $<3$ million

$$
\begin{aligned}
& \text { Category A: } 90,000 \\
& \text { Category B: } 165,000 \\
& \text { Category C: } 315,000
\end{aligned}
$$

- Receipts between 3 and 6 million

Category A: 240,000

Category B: 390,000

Category C: 690,000

-Receipts $>6$ million

Category A: $2.5 \%$
Tax on individuals engaging in activities included in the industrial and commercial profit category.

CInternational Monetary Fund. Not for Redistribution
Based on the general income tax since 1984.

New Feature: Art. 26 of the Tax Act of 99 provides that "any person or entity that pays sums that are subject to income tax in the revenue categories set forth in this chapter must withhold the tax at the source on behalf of the Treasury."

Art. 21 Tax Act of 2001

"The minimum tax is withheld at the source by the suppliers for the persons listed below:

-beverage wholesalers: $5 \%$

- cigarette wholesalers: 5\%

- merchants buying from wholesalers or

semi-wholesalers: $3 \%$

-pharmacists: $3 \%$

- importers: 3\%

- service station managers: $1 \%$

New Feature: Article 28 of the Tax Act of 2003 provides that all transactions carried out by individuals who do not have their tax residence in the C.A.R. are subject to source withholding of the minimum tax at the rate of $2 \%$. A nonresident taxpayer must

designate an accredited representative in the C.A.R., who shall be jointly and severally 
Table 30. Central African Republic: Summary of the Tax System, End of 2002 and Tax Act of 2003

(All amounts in CFA francs)

\subsubsection{Income from securities} (see Law No. 008/88)

1.2.3 Tax on professional income: minimum tax on individuals (MF)

\section{Category B: $5 \%$}

Category C: $10 \%$

A: providers of services (except those in categories $\mathrm{B}$ and $\mathrm{C}$ ) : agricultural companies; (Category A: merchants in business license classes 8 and 9 ).

The minimum tax must be withheld for individuals or legal entities subject to the income tax.

Shares in stock corporations or limited liability companies and similar income are subject to the income tax (IR-subcategory "income from taxable assets").

Other income distributed, obligations, income from loan claims, deposits, guarantees, etc., are subject to at-source withholdings, credited against the income tax (IR).

Levied on individuals engaged in the professions; holders of official office; profitmaking operations and sources of profit not included in categories $\mathrm{A}$ and $\mathrm{B}$; and taxpayers included in category C-2.

- The minimum tax on individuals established for a particular year will be charged against the income tax (IR) due for said year.

-It can only be deducted from the amount of the income tax (IR) due in the relevant category. liable with him for the payment of the tax. If no representative is appointed, the minimum tax and any penalties must be paid by the client for the account.

\section{Minimum withholding:}

beverage wholesalers, $5 \%$;

tobacco wholesalers, $5 \%$; oil and soap wholesalers, $3 \%$;

pharmacists, 3\%; importers, 3\%; service station managers, $1 \%$

Tax Act/99- Art. 34

New rates: $15 \%$, withbeld at source.

The minimum tax is determined as follows:

Total revenues or receipts generated in the year prior to the payment. Category $\mathrm{C}-2$

Less than CFAF 6 million: CFAF 690,000

Greater than CFAF 6 million: $10 \%(690,000+10 \% \mathrm{CA}>6$ million $)$ 
Table 30. Central African Republic: Summary of the Tax System, End of 2002 and Tax Act of 2003

(All amounts in CFA francs)

$\operatorname{Tax}$

\subsubsection{Wages and salaries}

1.2.5 Income tax

(IR) Tax Act of 99
Nature of Tax

-If it is higher, it is forfeited to the treasury

See minimum lump-sum tax (impôt forfaitaire sur le revenu des personnes physiques-IFPP)

Levied on net annual income received or earned, regardless of source.

There is a $30 \%$ deduction from the base for wages and salaries. Includes the revenue calculated for each category.

Includes income as calculated for each category.

\section{Exemptions and \\ Rates \\ Deductions}

Family status is taken into account by applying the system of income splitting (quotient familial), as follows:

one share for the spouse; and a half-share for each dependent child, up to five shares per family.

0 to $360,000(30,000 \times 12)$ 360,000 to 600,000

For each share, the

taxable base is determined by multiplying the net annual revenue by a percentage established in the Tax Act. Since the Tax Act of 1994, any revenue less than CFAF 360,000 has been taxexempt.

Revenue in excess of this amount is divided into 8 brackets that are successively taxed at a very progressive effective rate, where the marginal rate is 50 (Art. 19, Tax Act of 2000). 
Table 30. Central African Republic: Summary of the Tax System, End of 2002 and Tax Act of 2003

(All amounts in CFA francs)

Tax

Rates

1.2.6 Additional tax (TA)

1.2.7 Minimum lump-sum tax (impôt forfaitaire sur le revenu des personnes physiques - IFPP)

1.2.8 Special tax on the purchase of diamonds, gold, and precious stones

2. Employers' payroll tax (contribution de développement social - CDS)

3. Taxes on property

3.1 Taxes on real estate

Tax on improved land (contribution foncière des propriétés bâties)
Levied on individuals.

Minimum income tax levied on individuals in particular occupations and income groups and retired personnel with monthly revenue exceeding CFAF 30,000.

Tax on the proceeds of sales of diamonds, gold and precious stones withheld by purchasing offices and repaid to the Principal Tax Collector in Bangui.

Levied on total amount of wages, salaries, benefits in kind, and other cash payments by employers to their employees.

Levied on improved land, company premises, and buildings owned by individuals.
None.

Monthly remuneration less than CFAF 30,000 is exempt.

A deduction of $40 \%$ of the assessed rental value is allowed.

Permanent exemptions:

-public buildings and the majority of dwellings in

rural areas.

- Tax Act of 99, Art. 44, the first primary residence occupied by the owner and/or his family.
CFAF 1,500 annually.

For individuals subject to the license (patente), advance payment of $50 \%$ of the license due, with a minimum of CFAF 6,500 .

For wage earners, $5 \%$ of income and wages, less social security and pension fund contributions, withheld at source.

$3 \%$.

Normal rate: $10 \%$

Rate: $30 \%$ on companies (centimes eliminated)

Rate: $15 \%$ for individuals and legal entities subject to the tax on companies on $60 \%$ of the annual rental value.

The rate for calculating the rental value, which is applied to the current value or the cost price of fixed assets, is $8 \%$ for owneroccupied dwellings and $12 \%$ for all other buildings. 
Table 30. Central African Republic: Summary of the Tax System, End of 2002 and Tax Act of 2003

(All amounts in CFA francs)

Tax

4.1 Tax on turnover

(TCA)

Relevant provisions were repealed by

Article 34 of the Tax Act of 2000

Value-added tax (Law 2000-2001 of February 29, 2000) Article 34

4.2 Excise duty

Law 94/006 of October 8, 1995

Law 95.04 of December 31, 1995 and

Law 02.001 Tax Act of 2003

4.3 Other taxes and duties on services

4.3.1 Tax on gambling, amusements, and attractions (Law 95.001 of February 22 , 1995)

4.3.2 Tax on gambling profits

Nature of Tax Exemptions and Rates

Deductions

Exemptions are provided VAT rate $18 \%$. for. activities involving production, trade or provision of services by legal entities (companies, partnerships), not by individuals, whose turnover exceeds 30 million francs, including, including the professions, farming, mining, civilian activities and operations involving exploitation of assets. A

reimbursement procedure is provided for.

Specific tax applicable to products listed in CEMAC regulations. These include alcohol tobacco, cement, tea, salt, eggs, cosmetics, luxury goods (such as caviar and salmon), cameras, passenger vehicles of more than 1.6 liter displacement, arms and explosives.

Specific tax levied on company or individual sales from gambling, amusements, and attractions.

Gambling machines are subject to a licensing fee.

The taxes on profits from gambling are withheld by gambling companies or the
Cement.

23\% (Article 37 Tax Act of 2003)
CFAF 10,000 per year per machine. Rates by profit level. 
Table 30. Central African Republic: Summary of the Tax System, End of 2002 and Tax Act of 2003

(All amounts in CFA francs)

Tax

Nature of Tax

Exemptions and

Rates

Deductions

4.3.3 Tax on bank credit

(taxe sur la distribution du crédit)

(Order No. 74.101 of January 24, 1974;

suspended by Law $96 / 024$ of

September 22, 1996)

4.3.4 Tax on transfers

(taxe sur les transferts)

4.4 Taxes on use of goods or property and fees on permission to engage in activities

4.4.1 Business and professional licenses

4.4.1.1 Business licenses (patentes) individuals who are in charge of their weekly collection by the Tax Service.

Levied on loans granted by banking institutions.

Fee levied on transfers of funds outside the monetary zone of issue (BEAC).

Levied on companies or individuals engaged in industrial, commercial, and noncommercial activities.

In 1994, the activities of landscape architects and gambling establishments were included in Table A and cassette recording studios and games of chance were added to Table B.

As of January 1, 1994, the tax on diamondmining activities was increased in exchange for a decrease in the tax on exports of rough diamonds from $10 \%$ to $8 \%$.

Repealed (Tax Act of 99/Article 38)

$1 \%$.

Transfers to countries within franc zone: $0.25 \%$

Transfers outside franc zone: $0.5 \%$.

Exemptions:

-artists, fishermen, and

nurses;

- central and local

governments;

- casual renters;

- producer and consumer cooperatives;

- agricultural associations and cooperatives.
The professions are classified in two tables, $A$ and $B$ :

- Table A covers nine classes of companies, and the fees associated with each are in turn subdivided into four zones. The fees range from CFAF 5,000 to CFAF 10,000

-Table $B$ includes a fixed fee ranging from CFAF 2,000 to CFAF 2,500,000, plus variable fees depending on the number of machines used.

-For those subject to the business license

in Table A, $3 / 4$ of the fees are fixed

- $1 / 4$ of the fees vary on the basis of the

rental value of the professional facilities

- On January 1, 1994, the contributions in the table were adjusted between $5 \%$ and 
Table 30. Central African Republic: Summary of the Tax System, End of 2002 and Tax Act of 2003

(All amounts in CFA francs)

4.4.1.2 Alcoholic beverage license

4.4.1.3 Flat business tax (impôt libératoire) Article 16 Tax Act of 2001 amended in Tax Act of 2003

4.4.2 Tax on vehicles (taxe de circulation des véhicules à moteur et des bicyclettes),

eliminated and replaced by the tax on fuel

consumption (taxe sur la consommation des hydrocarbures)

5. Taxes on international trade

5.1 Common external tariff

(tarif extérieur commun-TEC)

5.1.1 Customs duties (droits d'entrée)
Levied on individual and entities selling

None

alcoholic beverages (in addition to the business license referred in 4.4.1.1 above)

Exclusive of all other taxes except for VAT, and is imposed on individuals who operate a business, an industry or a profession in the

C.A.R. and whose annual revenues, all taxes included, do not exceed CFAF 30,000,000.

Annual tax on cars.

Levied on CIF values of imported goods, including imports related to public contracts, irrespective of the financing sources.
$20 \%$, and those in Table B by $15 \%$.

-Amount of business licenses for diamond trade (CFAF in millions):

purchasing bureaus: CFAF 15 million purchasing centers: CFAF 2.5 million authorized buyers: CFAF 500,000 artisans: CFAF 30,000.

From CFAF 10,000 to CFAF 130,000, depending on the business and the region.

Minimum revenue CFAF 35,000 less than or equal to CFAF 500,000 .

Vehicles owned by central and local

governments

Imports explicitly exempted under CEMAC regulations (and international conventions).

$\begin{array}{lc}\text { Category } & \text { Rate (in percent) } \\ \text { I. Essential goods } & 5 \\ \begin{array}{l}\text { II. Raw materials and } \\ \quad \text { capital goods }\end{array} & 10 \\ \begin{array}{l}\text { III. Intermediate and } \\ \text { miscellaneous goods }\end{array} & 20 \\ \text { IV. Consumer goods } & 30\end{array}$


Table 30. Central African Republic: Summary of the Tax System, End of 2002 and Tax Act of 2003

(All amounts in CFA francs)

\begin{tabular}{|c|c|c|c|c|}
\hline $\operatorname{Tax}$ & & Nature of Tax & $\begin{array}{l}\text { Exemptions and } \\
\text { Deductions }\end{array}$ & Rates \\
\hline 5.1 .2 & Temporary surcharge & $\begin{array}{l}\text { Surcharge to protect some local products } \\
\text { listed in CEMAC regulations. To be } \\
\text { eliminated effective June } 30,2000 .\end{array}$ & No longer applied. & $30 \%$. \\
\hline 5.1 .3 & $\begin{array}{l}\text { Additional tax for regional integration } \\
\text { (taxe communautaire d'intégration) }\end{array}$ & $\begin{array}{l}\text { Additional tax on certain goods, earmarked } \\
\text { for the CEMAC. }\end{array}$ & & $\begin{array}{l}1 \% \text { for imports in categories III and IV; } \\
2.5 \% \text { for goods subject to excise duty. }\end{array}$ \\
\hline 5.1 .4 & $\begin{array}{l}\text { Duties, taxes and levies on petroleum } \\
\text { products }\end{array}$ & $\begin{array}{l}\text { Specific levies on high octane gasoline, } \\
\text { kerosene, and diesel fuel consist of customs } \\
\text { duties (DE), special tax on petroleum products } \\
\text { (TP), levy on road usage (RUR), and other } \\
\text { taxes and duties (RD). }\end{array}$ & & See Table 11 \\
\hline 5.1 .5 & Exemption processing fee & $\begin{array}{l}\text { Levied on tax-exempt imports under } \\
\text { regulatory and international conventions, as } \\
\text { well as imports related to public contracts } \\
\text { entered into before December } 31,1995 \text {. }\end{array}$ & $\begin{array}{l}\text { Official grants, imports } \\
\text { subject to the Diplomatic } \\
\text { Vienna Convention and } \\
\text { the convention on UN } \\
\text { privileges, and other } \\
\text { exemptions provided for } \\
\text { under CEMAC } \\
\text { regulations. }\end{array}$ & $8 \%$. \\
\hline 5.1 .6 & $\begin{array}{l}\text { Tax earmarked for the C.A.R. council } \\
\text { of customs brokers and the } \\
\text { computerization of the Ministry of } \\
\text { Finance }\end{array}$ & Levied on imported and exported goods. & & $\begin{array}{l}0.5 \% \text {, of which } 0.25 \% \text { for the council of } \\
\text { customs brokers and } 0.25 \% \text { for the } \\
\text { computerization of the Ministry of Finance. }\end{array}$ \\
\hline 5.1 .7 & Statistical tax & $\begin{array}{l}\text { Levied on imports monitored by the import } \\
\text { certification agency (SGS--Société Générale } \\
\text { de Surveillance). }\end{array}$ & $\begin{array}{l}\text { Import value of less than } \\
\text { CFAF } 3 \text { million. }\end{array}$ & $\begin{array}{l}1 \% . \text { F } 140,000(\mathrm{VI})>3,000,000 \\
\text { F } 25,000 \text { for DIC } \\
\text { (VI: taxable value; DIC: commercial import } \\
\text { declaration). }\end{array}$ \\
\hline
\end{tabular}


Table 30. Central African Republic: Summary of the Tax System, End of 2002 and Tax Act of 2003

(All amounts in CFA franes)

$\begin{array}{lll}\text { Tax } & \text { Nature of Tax } & \begin{array}{l}\text { Exemptions and } \\ \text { Deductions }\end{array}\end{array}$

5.2 Export duties

5.2.1 Export duty (droit de sortie)

6. Other taxes and duties

6.1 Stamp duty (Code on Recording Taxes,

Income from Securities and Stamp Duty,

1958, amended in 1970 (CET))

6.1.1 Recording tax
Assessed on f.o.b. value of exported goods; this is often replaced by a reference value (valeur mercuriale) determined by the government.

Assessed on the declared value of a legal act and applied to various legal documents.

\begin{tabular}{llr}
$\begin{array}{l}\text { Exports realized directly } \\
\text { by Red Cross or similar }\end{array}$ & Product & Rate (in per \\
charitable organizations & Timber & 10.75 \\
are exempt. The tax is & Processed wood & 4.75 \\
suspended on tobacco, & Diamonds & 5.0 \\
which is exported under & Gold: & 3.0 \\
supervision of the C.A.R. & & \\
\multicolumn{2}{l}{ Tobacco Company (SCT). } &
\end{tabular}

10.75 5.0

For the primary taxes:

- Proportional rates between $4 \%$ and $6 \%$

-Fixed rates: CFAF 20,000.

- Rates between 2,000 and 200,000

depending on the type of document

- Article 43 of Law 95,001 of February 22

1995 introduced supplementary rates on stamp duties.

Tax Act/99

Article 40: "Public works contracts and other contracts awarded by the Central

Government and the local authorities or public establishments are subject to

recording tax at a rate of $3 \%$."

- Capital increases via contribution of rea

or personal property : $4 \%$ instead of $3 \%$

- Minimum levied for proportional tax:

CFAF 20,000 
